Prepared in cooperation with the Department of the Interior Southeast Climate Adaptation Science Center

\title{
Science Needs of Southeastern Grassland Species of Conservation Concern: A Framework for Species Status Assessments
}

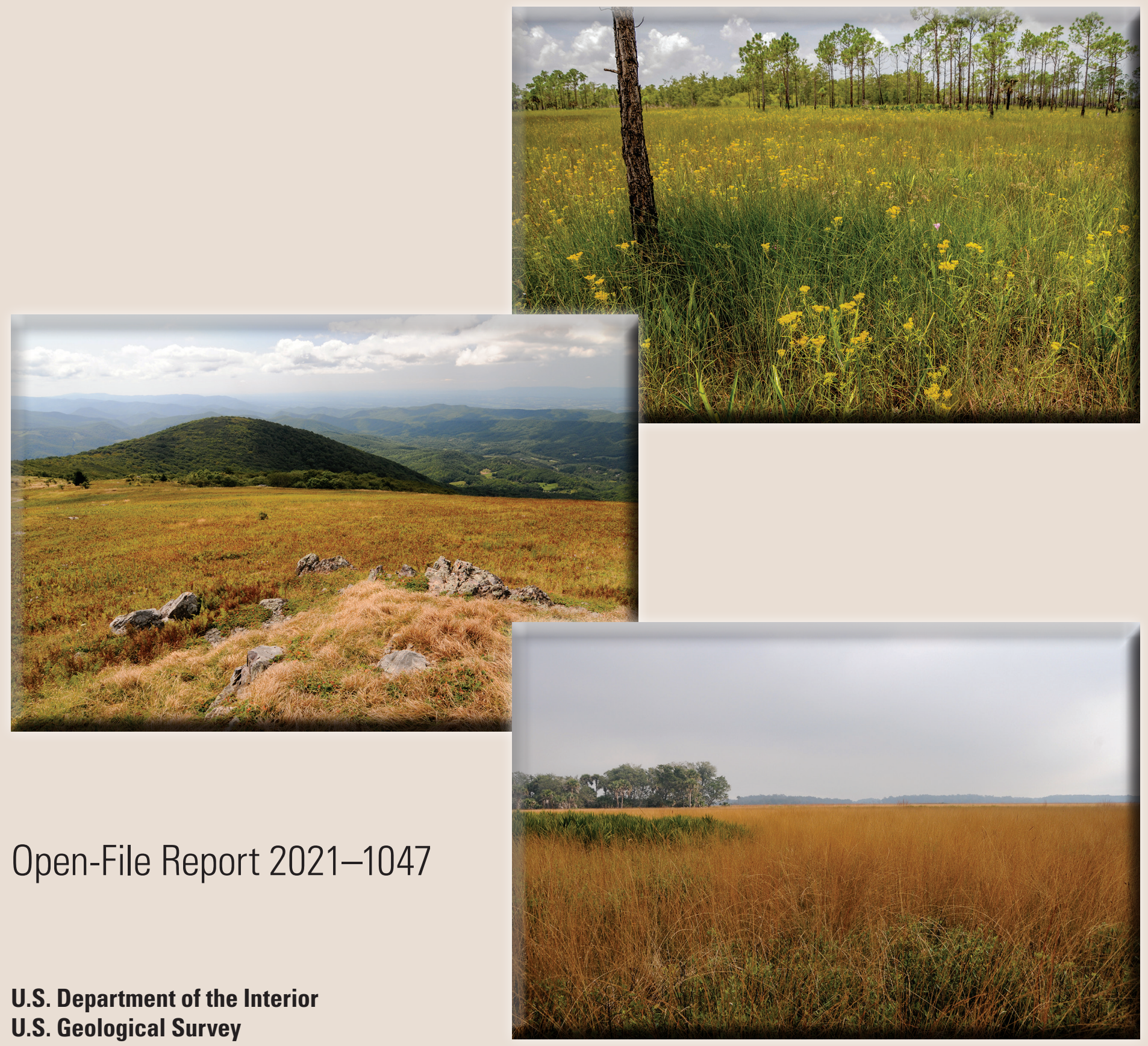




\section{Cover:}

Top, Marl prairie at Big Cypress National Preserve, Florida, July 2009. Photograph by Reed Noss, Florida Institute for Conservation Science, used with permission.

Left, Grass bald at Whitetop Mountain, Virginia, September 2009. Photograph by Reed Noss, Florida Institute for Conservation Science, used with permission.

Right, Florida dry prairie, December 2012. Photograph by Reed Noss, Florida Institute for Conservation Science, used with permission. 


\section{Science Needs of Southeastern Grassland Species of Conservation Concern: A Framework for Species Status Assessments}

By Reed F. Noss, Jennifer M. Cartwright, Dwayne Estes, Theo Witsell, K. Gregg Elliott, Daniel S. Adams, Matthew A. Albrecht, Ryan Boyles, Patrick J. Comer, Chris Doffitt, Don Faber-Langendoen, JoVonn G. Hill, William C. Hunter, Wesley M. Knapp, Mike Marshall, Milo Pyne, Jason R. Singhurst, Christopher Tracey, Jeffrey L. Walck, and Alan Weakley

Prepared in cooperation with the Department of the Interior Southeast Climate Adaptation Science Center

Open-File Report 2021-1047 


\section{U.S. Geological Survey, Reston, Virginia: 2021}

For more information on the USGS - the Federal source for science about the Earth, its natural and living resources, natural hazards, and the environment-visit https://www.usgs.gov or call 1-888-ASK-USGS.

For an overview of USGS information products, including maps, imagery, and publications, visit https://store.usgs.gov.

Any use of trade, firm, or product names is for descriptive purposes only and does not imply endorsement by the U.S. Government.

Although this information product, for the most part, is in the public domain, it also may contain copyrighted materials as noted in the text. Permission to reproduce copyrighted items must be secured from the copyright owner.

Suggested citation:

Noss, R.F., Cartwright, J.M., Estes, D., Witsell, T., Elliott, K.G., Adams, D.S., Albrecht, M.A., Boyles, R., Comer, P.J., Doffitt, C., Faber-Langendoen, D., Hill, J.G., Hunter, W.C., Knapp, W.M., Marshall, M., Pyne, M., Singhurst, J.R., Tracey, C., Walck, J.L., and Weakley, A., 2021, Science needs of southeastern grassland species of conservation concern-A framework for species status assessments: U.S. Geological Survey Open-File Report 2021-1047, 58 p., https://doi.org/10.3133/ofr20211047.

ISSN 2331-1258 (online) 


\section{Acknowledgments}

We would like to thank and acknowledge the support of Austin Peay State University for providing support to the Southeastern Grasslands Initiative in organizing the workshop described in this report and to Bridgestone Americas, Inc., for donating their Bridgestone Environmental Education Classroom Habitat (BEECH) facility for convening the workshop. This research was funded by the U.S. Geological Survey Southeast Climate Adaptation Science Center, which is managed by the U.S. Geological Survey National Climate Adaptation Science Center. This report was improved based on peer reviews by Amy Jenkins (Florida Natural Areas Inventory) and Keith Bradley (South Carolina Department of Natural Resources). 



\section{Contents}

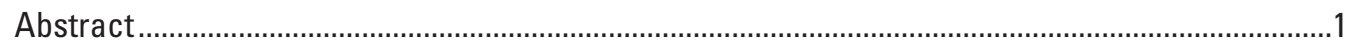

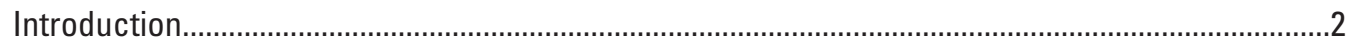

Factors Important in the Origin, Maintenance, and High Species Richness and

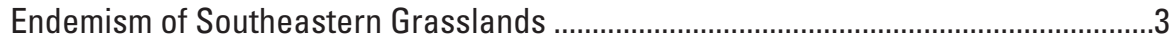

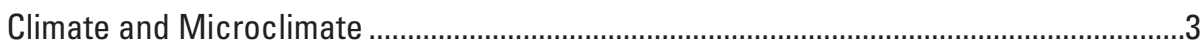

Box 1. A working definition of southeastern grasslands .................................................

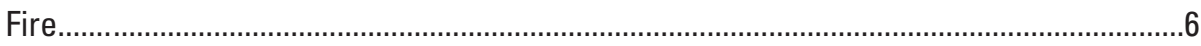

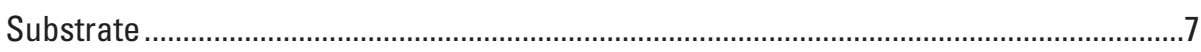

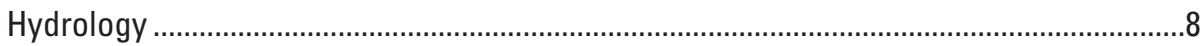

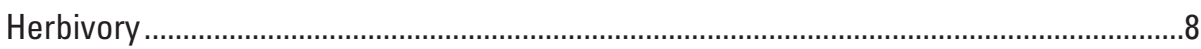

Other Disturbances and Combinations .......................................................................

Why Are Southeastern Grasslands So Biologically Diverse? ................................................

The Role of Species Status Assessments in Grassland Conservation .....................................10

Assessment of Science Needs for Southeastern Grasslands: Methods .................................11

Results: Science and Information Needed To Support Conservation of Southeastern

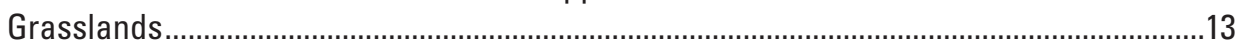

Habitat Loss, Fragmentation, and Disruption of Functional Population Connectivity .............13

Mapping and Modeling...................................................................................................

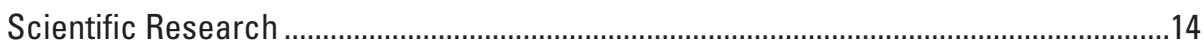

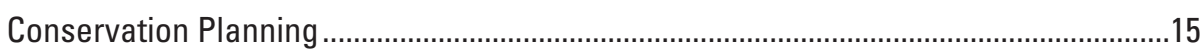

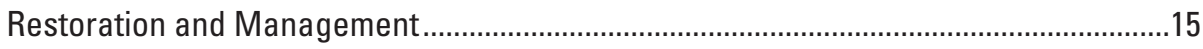

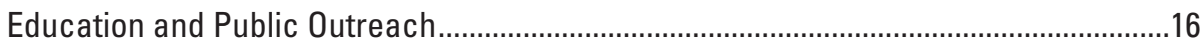

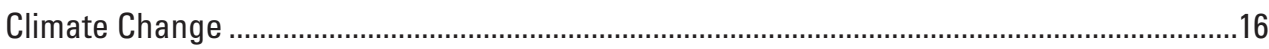

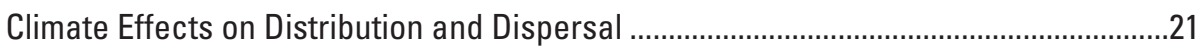

Role of Physiology and Phenology in Shaping Species Responses to

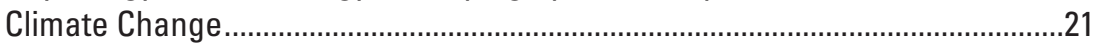

Impacts of Climate Change on Management Options and Constraints...........................22

Climate-Change Effects on Exotic and Invasive Species .............................................23

Increasing Frequency of Extreme Events: Precipitation and Drought............................24

Climate Effects on Distribution and Dispersal ...............................................................24

Impacts of Climate Change on Disturbance Regimes ..................................................24

Climate Change and Hydrologic Shifts in Wetland/Grassland Ecosystems ...................24

Sea-Level Rise and Coastal Grasslands .........................................................................24

Miscellaneous/“Complete Unknowns" ...........................................................................25

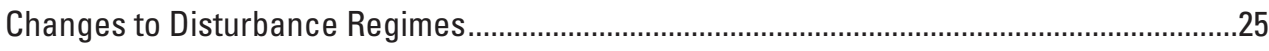

General Research Questions Related to Disturbance Regimes .....................................25

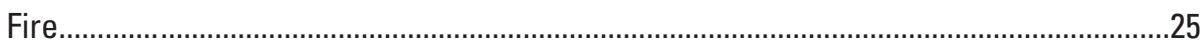

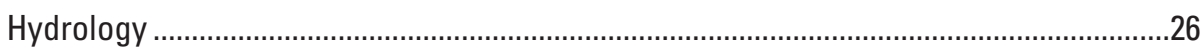

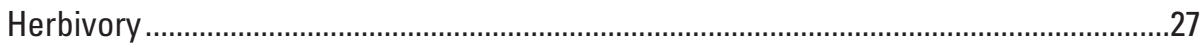

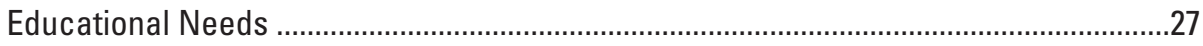

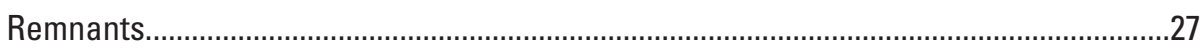

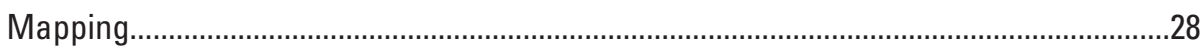

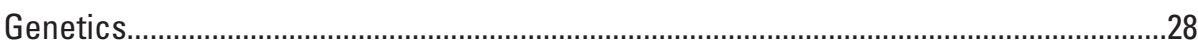


Invasive Species (Not Limited to Nonnative Species) ……..................................................28

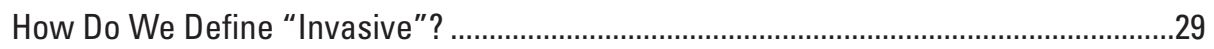

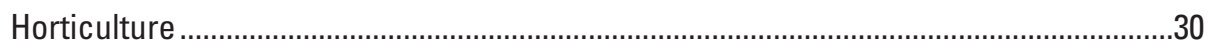

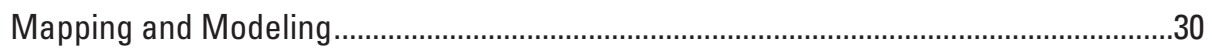

Resiliency of Ancient, Old-Growth, Remnant Grasslands .............................................30

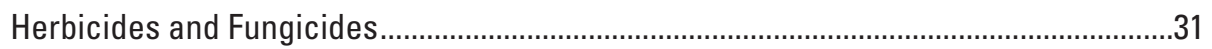

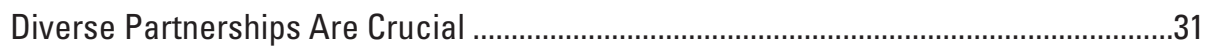

Invasive Species Issues Are Often Site-Specific and May Not Be the Primary

Management Concern...........................................................................................

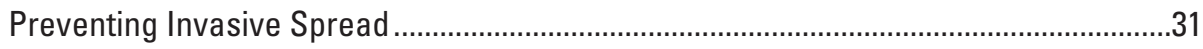

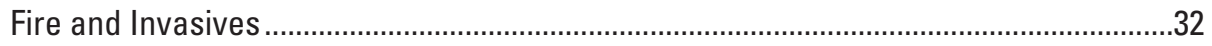

Specific Cases of Invasives ...........................................................................................32

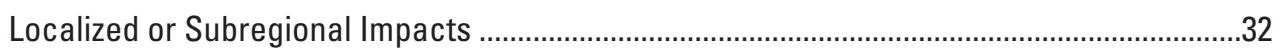

Inventory

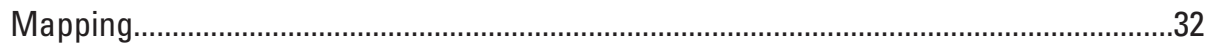

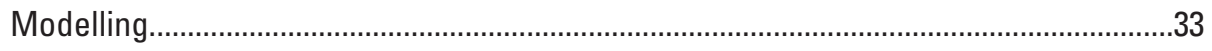

Management, Conservation Actions, and Concerns ....................................................33

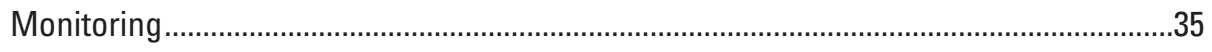

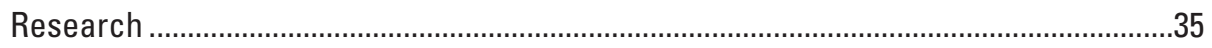

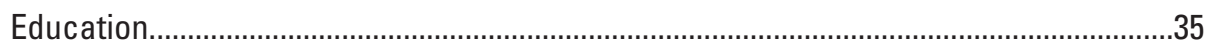

Next Steps and Remaining Research Questions and Science Needs ..................................36

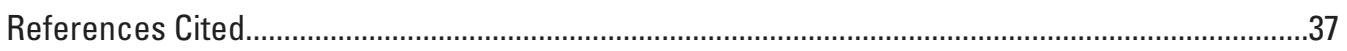

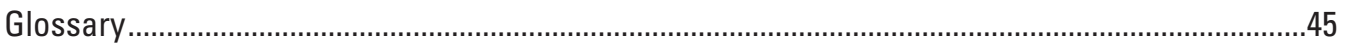

Appendix 1. Grassland Ecosystems of the Southeastern United States .....................................47

Appendix 2. Southeastern Climate and Grasslands Workshop: Summary of Survey Results.....55

\section{Figures}

1. Map showing summed range-size rarity of imperiled species from the Map of Biodiversity Importance.

2. Map showing the southeastern U.S. grasslands study region: the biogeographic Southeast as defined by the Southeastern Grasslands Initiative .....

3. Diagram showing a general model for the origin and maintenance of southeastern grasslands.

4. Maps showing projections for the number of warm nights per year in the Southeast for the mid-21st century and the late 21st century under a higher scenario and a lower scenario

5. Maps showing shifts in plant hardiness zones by the late 21 st century under a higher scenario

6. Graph and map showing trends in days with heavy precipitation (1900-2016) averaged over the Southeast by decade and individual station trends (1950-2016) ......19

7. Map showing the Southeast Conservation Adaptation Strategy geography....................34

8. Map showing the Southeast Conservation Blueprint $\ldots 34$ 


\section{Tables}

1. Vertebrate species associated entirely or in part with grassland habitat in Florida that are federally listed under the U.S. Endangered Species Act or are candidates for listing.

2. NatureServe terrestrial ecological systems that qualify as grasslands according to the definition in this report occur in the southeastern United States and are considered critically endangered under the International Union for Conservation of Nature criteria

3. Participants in the workshop in Morrison, Tennessee, January 22-23, 2020,

"Assessing the Science Needs of Southeastern Grassland Species of Conservation Concern" 


\section{Conversion Factors}

U.S. customary units to International System of Units

\begin{tabular}{|c|c|c|}
\hline Multiply & By & To obtain \\
\hline \multicolumn{3}{|c|}{ Length } \\
\hline inch (in.) & 2.54 & centimeter $(\mathrm{cm})$ \\
\hline inch (in.) & 25.4 & millimeter $(\mathrm{mm})$ \\
\hline foot $(\mathrm{ft})$ & 0.3048 & meter $(\mathrm{m})$ \\
\hline yard (yd) & 0.9144 & meter $(\mathrm{m})$ \\
\hline \multicolumn{3}{|c|}{ Area } \\
\hline acre & 4,047 & square meter $\left(\mathrm{m}^{2}\right)$ \\
\hline acre & 0.4047 & hectare (ha) \\
\hline acre & 0.4047 & square hectometer $\left(\mathrm{hm}^{2}\right)$ \\
\hline acre & 0.004047 & square kilometer $\left(\mathrm{km}^{2}\right)$ \\
\hline square mile $\left(\mathrm{mi}^{2}\right)$ & 259.0 & hectare (ha) \\
\hline
\end{tabular}

International System of Units to U.S. customary units

\begin{tabular}{lll}
\hline \multicolumn{1}{c}{ Multiply } & By & \multicolumn{1}{c}{ To obtain } \\
\hline centimeter $(\mathrm{cm})$ & Length & inch (in.) \\
millimeter $(\mathrm{mm})$ & 0.3937 & inch (in.) \\
meter $(\mathrm{m})$ & 0.03937 & foot (ft) \\
meter $(\mathrm{m})$ & 3.281 & yard (yd) \\
\hline & 1.094 & \\
\hline square meter $\left(\mathrm{m}^{2}\right)$ & Area & acre \\
hectare (ha) & 0.0002471 & acre \\
square hectometer $\left(\mathrm{hm}^{2}\right)$ & 2.471 & acre \\
square kilometer $\left(\mathrm{km}^{2}\right)$ & 2.471 & acre \\
hectare (ha) & 247.1 & square mile $\left(\mathrm{mi}^{2}\right)$ \\
\hline
\end{tabular}

Temperature in degrees Celsius $\left({ }^{\circ} \mathrm{C}\right)$ may be converted to degrees Fahrenheit $\left({ }^{\circ} \mathrm{F}\right)$ as follows: ${ }^{\circ} \mathrm{F}=\left(1.8 \times{ }^{\circ} \mathrm{C}\right)+32$.

Temperature in degrees Fahrenheit $\left({ }^{\circ} \mathrm{F}\right)$ may be converted to degrees Celsius $\left({ }^{\circ} \mathrm{C}\right)$ as follows: ${ }^{\circ} \mathrm{C}=\left({ }^{\circ} \mathrm{F}-32\right) / 1.8$. 


\section{Abbreviations}

$\begin{array}{ll}\text { ESA } & \text { Endangered Species Act } \\ \text { FQA } & \text { Floristic Quality Assessment } \\ \text { G1 } & \text { globally critically imperiled } \\ \text { G2 } & \text { globally imperiled } \\ \text { IUCN } & \text { International Union for Conservation of Nature } \\ \text { lidar } & \text { light detection and ranging } \\ \text { NCA4 } & \text { 4th National Climate Assessment } \\ \text { NG0 } & \text { nongovernmental organization } \\ \text { RCP4.5 } & \text { Representative Concentration Pathway 4.5 (lower scenario for greenhouse } \\ & \text { gas concentrations in the atmosphere) } \\ \text { RCP8.5 } & \text { Representative Concentration Pathway } 8.5 \text { (higher scenario for greenhouse } \\ & \text { gas concentrations in the atmosphere) } \\ \text { SECAS } & \text { Southeast Climate Adaptation Strategy } \\ \text { SGI } & \text { Southeastern Grasslands Initiative } \\ \text { SSA } & \text { Species Status Assessment } \\ \text { USDA } & \text { U.S. Department of Agriculture } \\ \text { USFWS } & \text { U.S. Fish and Wildlife Service } \\ \text { USGCRP } & \text { U.S. Global Change Research Program }\end{array}$





\title{
Science Needs of Southeastern Grassland Species of Conservation Concern: A Framework for Species Status Assessments
}

\author{
By Reed F. Noss, ${ }^{1,2}$ Jennifer M. Cartwright, ${ }^{3}$ Dwayne Estes, ${ }^{2,4}$ Theo Witsell, ${ }^{2}$ K. Gregg Elliott, ${ }^{2,5}$ Daniel S. \\ Adams, ${ }^{6}$ Matthew A. Albrecht, ${ }^{7}$ Ryan Boyles, ${ }^{8}$ Patrick J. Comer, ${ }^{9}$ Chris Doffitt, ${ }^{10}$ Don Faber-Langendoen, ${ }^{9}$ \\ JoVonn G. Hill, ${ }^{11,12}$ William C. Hunter, ${ }^{6}$ Wesley M. Knapp, ${ }^{13}$ Mike Marshall, ${ }^{14}$ Milo Pyne, ${ }^{15}$ Jason R. Singhurst, ${ }^{16}$ \\ Christopher Tracey, ${ }^{17}$ Jeffrey L. Walck, ${ }^{18}$ and Alan Weakley ${ }^{19,20,2}$
}

\section{Abstract}

The unglaciated southeastern United States is a biodiversity hotspot, with a disproportionate amount of this biodiversity concentrated in grasslands. Like most hotspots, the Southeast is also threatened by human activities, with the total reduction of southeastern grasslands estimated as 90 percent (upwards to 100 percent for some types) and with many threats escalating today. This report summarizes the results of a multistakeholder workshop organized by the Southeastern Grasslands Initiative and the U.S. Geological Survey, held in January 2020 to provide a scientific needs assessment to help inform the Species Status Assessment (SSA) process under the U.S. Endangered Species Act, with a focus on grassland species and communities of conservation concern in the southeastern United States. This report reviews the ecology of southeastern grasslands, including influences on their origin, maintenance, and high species richness and endemism; presents findings from the workshop; and discusses science questions, hypotheses, and possibilities for future research projects to help fill key knowledge gaps.

Participants in the January 2020 workshop, representing diverse expertise in various topics in southeastern grassland

\footnotetext{
${ }^{1}$ Florida Institute for Conservation Science

${ }^{2}$ Southeastern Grasslands Initiative

${ }^{3}$ U.S. Geological Survey

${ }^{4}$ Center of Excellence for Field Biology, Austin Peay State University

${ }^{5} \mathrm{~K}$ Gregg Consulting

${ }^{6}$ U.S. Fish and Wildlife Service

${ }^{7}$ Center for Conservation and Sustainable Development, Missouri Botanical Garden

${ }^{8}$ Department of the Interior Southeast Climate Adaptation Science Center

${ }^{9}$ NatureServe

${ }^{10}$ Louisiana Department of Wildlife and Fisheries
}

ecology, were tasked with identifying major threats to grassland species in the Southeast as well as potential ways to make the SSA process more efficient and effective. An underlying assumption and starting place for workshop discussion was that an ecosystem-based approach to the SSA process is more cost-efficient than a species-by-species approach, in large part because many species with similar biological requirements can be addressed by the same actions. Nevertheless, one partner in this effort, the U.S. Fish and Wildlife Service, does require specific attention be given to taxa that have been petitioned for Federal listing, though as often as possible these taxa are considered alongside a larger group of priority taxa with an ecosystem approach.

For group discussions, workshop participants followed a modified "World Café" method, a structured conversational approach for knowledge sharing. Group discussions focused on five categories of threats to grassland communities and species: (1) habitat loss, fragmentation, and disruption of functional population connectivity; (2) climate change, especially changes in temperature and precipitation, including intensity and seasonality, and impacts on soil moisture, groundwater levels, and other ecosystem parameters; (3) changes to disturbance regimes, as influenced by climate and land-use change,

\footnotetext{
${ }^{11}$ Mississippi Entomological Museum

${ }^{12}$ Department of Biochemistry, Molecular Biology, Entomology, and Plant Pathology, Mississippi State University

${ }^{13}$ North Carolina Natural Heritage Program

${ }^{14}$ Texas A\&M Natural Resource Institute

${ }^{15}$ NatureServe, retired

${ }^{16}$ Texas Parks and Wildlife Nongame and Rare Species Program

${ }^{17}$ Pennsylvania Natural Heritage Program

${ }^{18}$ Department of Biology, Middle Tennessee State University

${ }^{19}$ University of North Carolina at Chapel Hill Herbarium (North Carolina Botanical Garden)

${ }^{20}$ University of North Carolina at Chapel Hill
} 
extinctions, and human attitudes and behaviors; (4) invasive species (not limited to nonnative species); and (5) localized or subregional impacts such as sea-level rise. In addition to group discussions, workshop participants - as well as other grassland experts who were unable to attend the workshopcompleted a preworkshop survey concerning challenges and opportunities for grassland conservation. Findings reported here under each of these topics represent ideas, problems, hypotheses, and questions identified by a diverse community of grassland managers and researchers which may be addressed by future research and monitoring in southeastern grassland ecosystems to help guide science-based conservation of grassland-dependent species.

\section{Introduction}

The southeastern United States is one of the richest regions of North America biologically and among the richest temperate and subtropical regions globally. Grasslands contribute disproportionately to this high biodiversity yet have received far less attention from conservationists and natural resources agencies than forests or wetlands. The North American Coastal Plain, historically dominated over much of its extent by pine savannas and other grasslands, is recognized as a global biodiversity hotspot (Critical Ecosystem Partnership
Fund, 2016; Noss and others, 2015), one of few temperate/ subtropical regions so recognized, due to its high levels of species endemism and habitat loss. Updated maps of biodiversity importance for the United States (fig. 1; Esri, 2020; NatureServe, 2021) show the southern Appalachians, Ouachita Mountains, Nashville Basin of Tennessee, and some other regions of the Southeast are almost as rich as the Coastal Plain in terms of concentrations of species that are federally listed as threatened or endangered or categorized by NatureServe as globally imperiled (G2) or critically imperiled (G1), most of them small-range endemics. Many of these imperiled species inhabit grasslands, as defined in box 1. For example, although there are fewer imperiled species of vertebrates associated with southeastern grasslands, as compared with plants and invertebrates, some 23 federally listed species of vertebrates in Florida alone are associated entirely or in part with grassland habitat (table 1).

Collectively, these grasslands dominated large areas of the biogeographic Southeast, defined here as a 24-State region of the unglaciated eastern United States (fig. 2). Southeastern grasslands covered at least 40-49 million hectares (ha) (100-120 million acres) prior to European settlement. Some researchers estimate a presettlement area of over 100 million ha (250 million acres) of open forest (woodland and savanna) across eastern North America (Hanberry and others, 2020). Ongoing research by NatureServe and the Southeastern Grasslands Initiative (SGI) will refine these estimates.

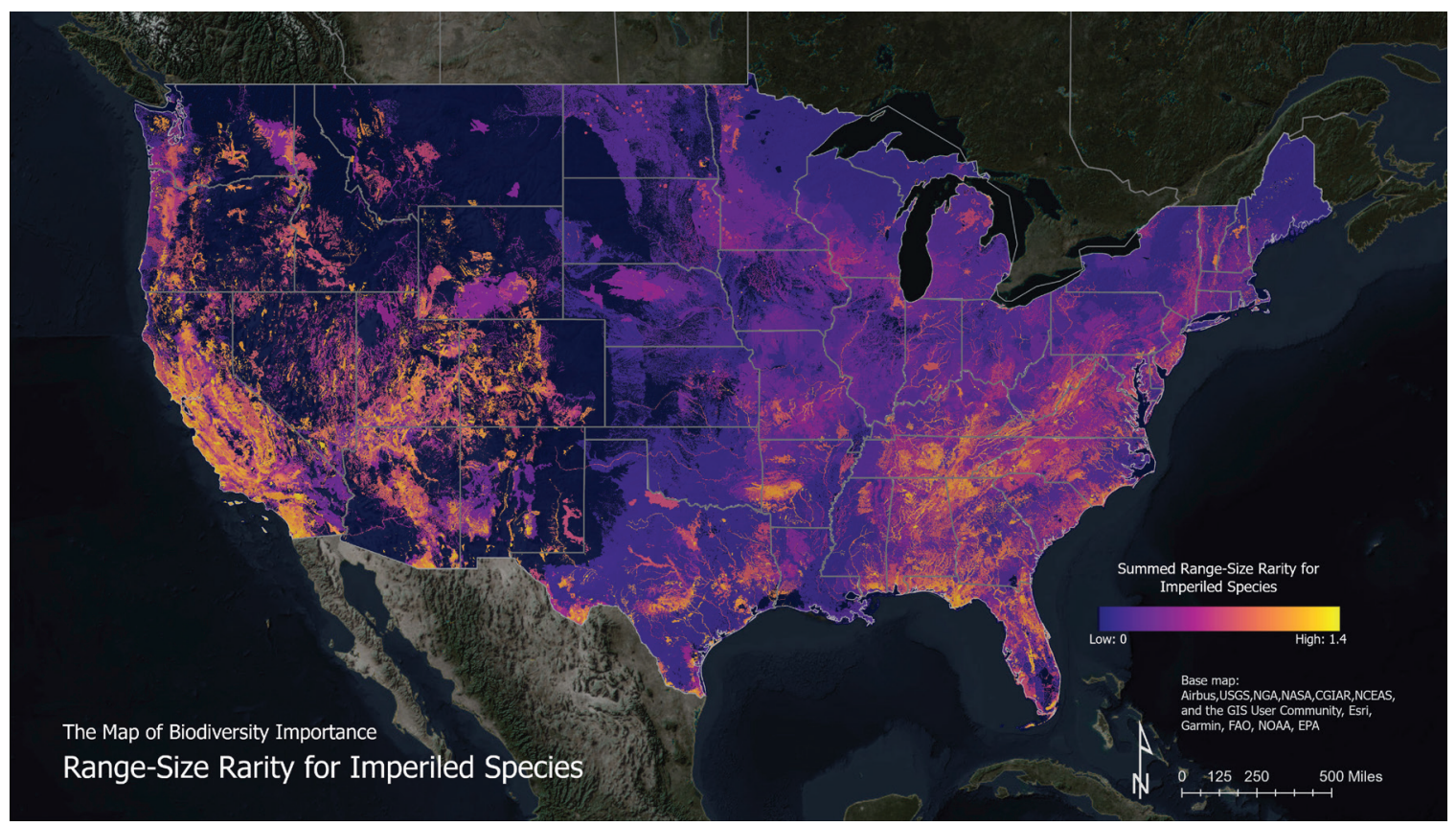

Figure 1. Summed range-size rarity of imperiled species from the Map of Biodiversity Importance (NatureServe, 2021). This map was developed from habitat suitability models for 2,216 species ranked as critically imperiled (G1), imperiled (G2), or listed as endangered or threatened under the U.S. Endangered Species Act. Taxa include vertebrates, vascular plants, selected aquatic invertebrates (mussels and crayfish), and selected pollinators (bumblebees, butterflies, and skippers). High values identify areas with greater numbers of imperiled species with restricted ranges. Details on the habitat models used to produce this map are available from NatureServe (2021). 


\section{Box 1. A working definition of southeastern grasslands}

For the purpose of this report and the collaborative efforts that produced it, a grassland is any community in which plant cover or biomass, and usually species richness, are concentrated in the grass or graminoid layer, with its associated forbs (adapted from Frost, 1998). This definition includes not only prairies, but also a range of other grassy ecosystems such as barrens, glades, outcrops, mountain balds, and coastal grasslands (for example, dunes), as well as fens, bogs, meadows, riverscour communities, canebrakes, marl prairies, and marshes (table 2), with the exclusion of tidal marshes, which we do consider as part of the broader grassland definition but consider beyond the scope of this effort. Some of these latter systems are almost continually wet, whereas others have a distinct seasonal hydroperiod or are maintained by periodic flooding. Our definition also encompasses treed grasslands, which fall in the continuum between treeless prairie and closed forest. In the Southeast, these are primarily open-canopy woodlands and pine (Pinus) and oak (Quercus) savannas (which some scientists refer to as "open forests"; Hanberry and others, 2020), as well as shrub-scrub communities that include openings supporting grassy-herbaceous species. An example of grassy openings in southeastern shrub-scrub communities is the sandy prairie patches surrounded by running live oak (Quercus virginiana) in the Coastal Bend of Texas. Working definitions for many southeastern grasslands are provided by Estes and others (2016). There are currently around 120 NatureServe terrestrial ecological systems that represent grasslands in the southeastern United States (appendix 1).

Across the entire Southeast, as well as North America and worldwide, various kinds of grasslands are the most endangered of all major categories of terrestrial ecosystems, with total reduction of southeastern grasslands estimated at 90 percent and with many types approaching 100 percent (Comer and others, 2018; Noss and others, 1995; Samson and Knopf, 1996). Most of the loss historically can be attributed to conversion of grasslands to agricultural production, but fire suppression has caused many types of grasslands to be replaced by forests and woodlands, and urban expansion is increasingly a threat. Other escalating threats include excessive mowing and herbicide application, off-road vehicle use and other intensive recreation, invasive species, climate change (including sea-level rise), and misguided afforestation for the purpose of carbon sequestration (Bond, 2016; Veldman and others, 2015). The extent of decline of southeastern grasslands is so great that their formerly expansive distribution is largely unknown or forgotten, even by many ecologists and conservationists (Noss, 2013). Using International Union for Conservation of Nature (IUCN) Red List of Ecosystems criteria, NatureServe recognizes 42 critically endangered (the highest IUCN category) terrestrial ecological systems in North America. Of these, 25 (59 percent) occur in the southeastern United States, and 20 (48 percent) are in southeastern grasslands, inclusive of savannas and open woodlands (table 2). The true number of imperiled ecosystems may be higher than these numbers suggest, since many ecological systems are unranked due to limited knowledge of their status. For example, some 154 ecological systems in Florida, Georgia, Alabama, South Carolina, and North Carolina are unranked (Keith Bradley, South Carolina Department of Natural Resources, written commun., 2020).

The major purpose of this report is to draw from the results of a multistakeholder workshop (described later) to provide guidelines for improving the Species Status Assessment (SSA) process under the U.S. Endangered Species Act (ESA) for grassland species and communities of conservation concern in the southeastern United States. This report reviews the ecology of southeastern grasslands; addresses findings from the workshop; and discusses science questions, hypotheses, and possibilities for future research projects to help fill key knowledge gaps identified by workshop participants. We hope this assessment will help to guide the development of collaborative research projects targeted at addressing the most pressing scientific needs for conserving southeastern grassland species of conservation concern. Developing guidance for improving the efficiency of the SSA process, especially through the application of an ecosystem approach, is also a major goal of this effort.

\section{Factors Important in the Origin, Maintenance, and High Species Richness and Endemism of Southeastern Grasslands}

To identify and address the threats to southeastern grassland communities and species, it is helpful to understand their origins and the factors that maintained them over time. An ecosystem-based (coarse filter) approach explicitly considers natural processes and the abiotic and biotic environment in which southeastern grasslands developed. A general model for the origin and maintenance of southeastern grasslands was presented by Noss (2013; fig. 3). The major factors that control grassland occurrence, historically and today, in the Southeast are summarized below.

\section{Climate and Microclimate}

A fundamental generalization of biogeography is that grassland biomes occur along a gradient of climatic moisture limitation between desert and forest (Coupland, 1991). This generalization, however, does not account for grasslands that occur in regions of the world with levels of precipitation sufficient to support forest. The southeastern United States receives vastly more precipitation than the prairie region of the Great Plains and more than enough to support closed forest, yet 
Table 1. Vertebrate species associated entirely or in part with grassland habitat in Florida (some occur also in other States) that are federally listed under the U.S. Endangered Species Act or are candidates for listing. Southeastern grasslands contain many more imperiled plant and invertebrate species than imperiled vertebrate species.

[E, endangered; T, threatened; $\mathrm{C}$, candidate]

\begin{tabular}{llc}
\hline \multicolumn{1}{c}{ Scientific name } & \multicolumn{1}{c}{ Common name } & $\begin{array}{c}\text { Federal } \\
\text { status }\end{array}$ \\
\hline Ambystoma bishopi & Reticulated flatwoods salamander & E \\
Ambystoma cingulatum & Frosted flatwoods salamander & $\mathrm{T}$ \\
Notophthalmus perstriatus & Striped newt & $\mathrm{C}$ \\
Drymarchon couperi & Eastern indigo snake & $\mathrm{T}$ \\
Gopherus polyphemus & Gopher tortoise & $\mathrm{C}$ \\
Nerodia clarkii taeniata & Atlantic salt marsh snake & $\mathrm{T}$ \\
Plestiodon egregious lividus & Blue-tailed mole skink & $\mathrm{T}$ \\
Plestiodon reynoldsi & Sand skink & $\mathrm{T}$ \\
Ammodramus savannarum floridanus & Florida grasshopper sparrow & $\mathrm{E}$ \\
Ammospiza maritima mirabilis & Cape Sable seaside sparrow & $\mathrm{E}$ \\
Caracara cheriway & Crested caracara & $\mathrm{T}$ \\
Dryobates borealis & Red-cockaded woodpecker & E \\
Eumops floridanus & Florida bonneted bat & E \\
Microtus pennsylvanicus dukecampbelli & Salt marsh vole & E \\
Odocoileus virginianus clavium & Key deer & E \\
Oryzomys palustris natator & Key rice rat & E \\
Peromyscus polionotus allophrys & Choctawhatchee beach mouse & E \\
Peromyscus polionotus niveiventris & Southeastern beach mouse & T \\
Peromyscus polionotus peninsularis & St. Andrews beach mouse & E \\
Peromyscus polionotus phasma & Anastasia Island beach mouse & E \\
Peromyscus polionotus trissyllepsis & Perdido Key beach mouse & E \\
Puma concolor coryi & Florida panther & E \\
Sylvilagus palustris hefneri & Lower Keys rabbit & E \\
\hline & & \\
\hline
\end{tabular}

historically it had abundant grassland (Noss, 2013). Why? The explanation is complex but primarily involves climate interacting with disturbance regimes, such as fire and herbivory.

Historic climatic changes and shorter term (for example, decadal) climate cycles likely played a role in the formation and maintenance of some or many southeastern grasslands. Periods of drier or hotter (that is, high evapotranspiration) climate would have promoted the spread of grassland vegetation from the Great Plains into eastern North America. Transeau (1935) suggested that the dry climate of the midHolocene (the Hypsithermal Interval or Holocene Climatic Optimum, around 9,000-5,000 years ago) produced a prairie peninsula that extended eastward from the Great Plains at least through central Ohio. Late-summer drought, competition from established grass cover inhibiting tree regeneration, possibly edaphic conditions (such as shallow soil), and fire then presumably allowed eastern grasslands to persist as a wetter climate returned. The patchy nature of this grassland vegetation suggests it might more accurately be considered a Prairie
Archipelago (Sears, 1981). Although the Prairie Peninsula/ Archipelago is well accepted for the glaciated Midwest, midHolocene drying may have been important in the expansion of western grassland taxa into the unglaciated Southeast as well (Baskin and others, 1997).

Earlier periods of hot or dry climate also may have favored dispersal of xeric-adapted species from more western regions into the Southeast. Braun $(1928,1951,1955)$ hypothesized that the limestone prairies of unglaciated southern Ohio were formed during the Middle Pleistocene and that they were composed of xeric grassland taxa dispersing not from the upper Mississippi Valley but from the "Ozark region and southward" (Braun, 1955). Considerably earlier, the Gulf Coastal corridor, which connected the southwestern United States to the Southeast, existed intermittently but over long stretches of time from the Late Miocene to the Early Pleistocene. This corridor of savanna and scrub vegetation facilitated dispersal of many species from the Southwest, Great Plains, and Neotropics into the southeastern Coastal Plain 


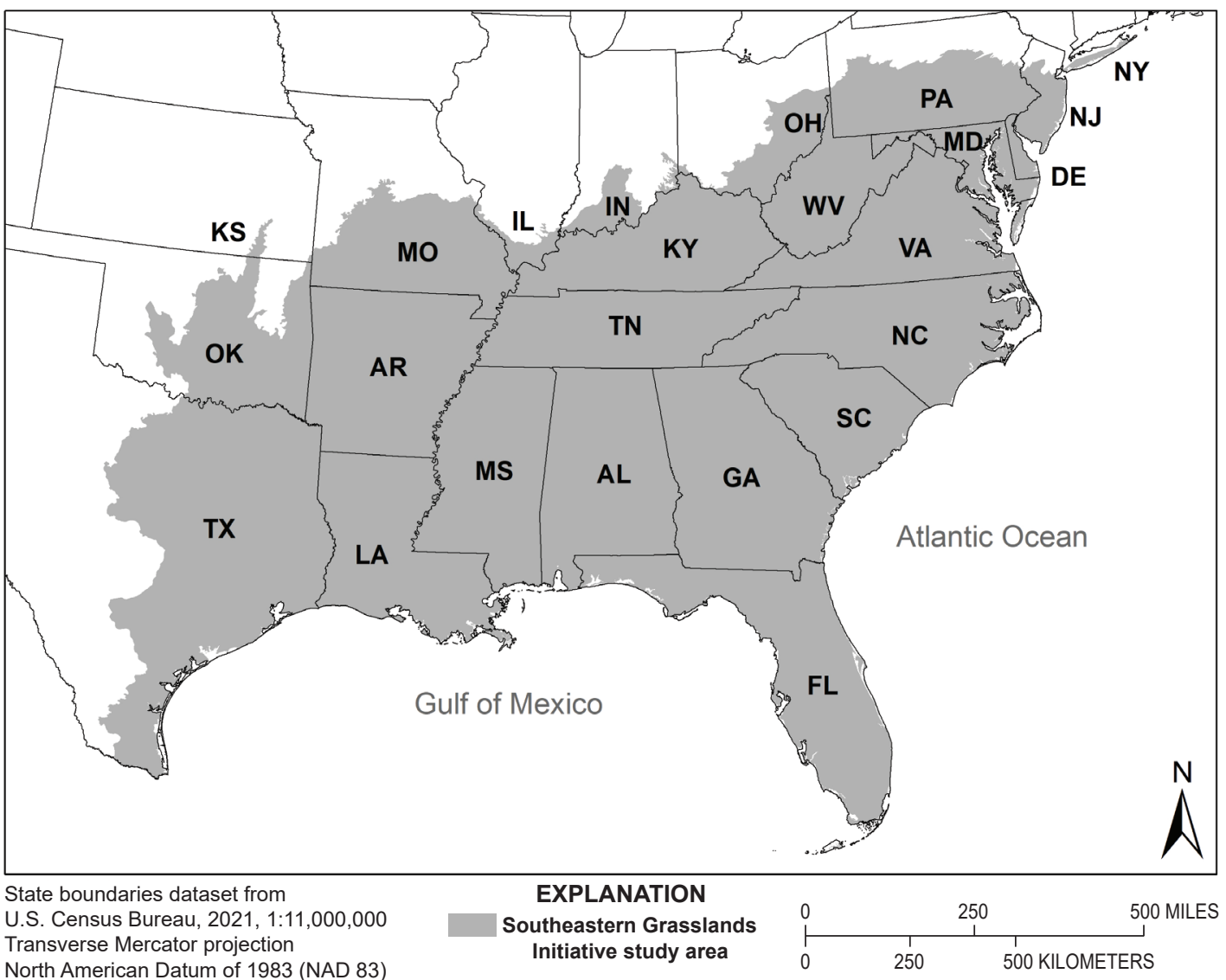

Figure 2. The southeastern U.S. grasslands study region: the biogeographic Southeast as defined by the Southeastern Grasslands Initiative. The northern boundary corresponds to the Wisconsinan and Illinoian glacial maxima, adjusted slightly by reference to U.S. Environmental Protection Agency (EPA) Level III and Level IV ecoregions (U.S. Environmental Protection Agency, 2013) where there is uncertainty about the glacial boundary. The western boundary is defined by EPA Level III and Level IV ecoregions to include those ecoregions with a dominant southeastern floristic affinity as opposed to a Great Plains, Tallgrass Prairie, or Madrean affinity.

and portions of adjacent regions (Morgan and Emslie, 2010; Noss, 2013; Webb, 1990). Most of these taxa survive in the Southeast today in physiologically xeric habitats such as deep sands. Among the numerous examples of southeastern grassland species that occur as eastern outliers or relatives of genera more common and (or) diverse in southwestern or western North America are genera such as Aristida, Astragalus, Boutelona, Dalea, Eriogonum, Grindelia, Krameria, Leavenworthia, Mimosa, Myriopteris, Nolina, Opuntia, Penstemon, Phemeranthus, Polanisia, Trichostema, and Yucca and the animals harvester ants, sand cockroaches, several species of grasshoppers, pocket gophers, gopher tortoise, whipsnakes (eastern coachwhip), white-tailed kite, crested caracara, Florida scrub-jay, and burrowing owl (Noss, 2013).

The southeastern Coastal Plain - most prominently peninsular Florida - has a characteristic "savanna climate," as defined by intermediate annual rainfall (100-250 centimeters or 39-98 inches) and mild to moderate seasonality (a distinct dry season shorter than 7 months) (Noss, 2013). North of central Florida, the winter dry season is split by a January-March secondary rainy season in most years, such that dry seasons occur in late fall and middle to late spring (Noss, 2018; Slocum and others, 2010). Previously, only portions of South America, Africa, and Australia were observed to meet the criteria for a savanna climate (Staver and others, 2011). With a savanna climate, closed forest and savanna can be alternative stable states, with savanna maintained by a positive fire-vegetation feedback loop (Fill and others, 2015). Savannas occurring today in areas wet enough to support forest were probably formed during periods, such as the Late Miocene, of dry or highly seasonal climate (Staver and others, 2011). A savanna climate favors a frequent-fire regime because the wet season allows development of lush herbaceous vegetation, which dries and becomes combustible during the dry season, and then is ignited by lightning toward the end of the dry season (Bond and others, 2005; Noss, 2018).

The effect of the modern climate on grassland distribution in the Southeast is displayed on a local as well as regional scale. Microclimate plays an important role in the distribution of many grassland types in the Southeast today, with an effect 
Table 2. NatureServe terrestrial ecological systems that qualify as grasslands according to the definition in this report occur in the southeastern United States and are considered critically endangered under the International Union for Conservation of Nature (IUCN) criteria. These 20 southeastern grassland types represent approximately half (48 percent) of the 42 critically endangered ecological systems in all of North America. From NatureServe (Explorer accessible at https://explorer.natureserve.org/).

[AL, Alabama; GA, Georgia; FL, Florida; MS, Mississippi; TN, Tennessee; LA, Louisiana; MD, Maryland; NC, North Carolina; NY, New York; PA, Pennsylvania; VA, Virginia; OK, Oklahoma; TX, Texas; SC, South Carolina; KY, Kentucky; OH, Ohio; AR, Arkansas; KS, Kansas; MO, Missouri]

\begin{tabular}{ll}
\hline \multicolumn{1}{c}{$\begin{array}{c}\text { Ecological system name (hyperlinked to NatureServe Explorer } \\
\text { Terrestrial Ecological Systems accounts) }\end{array}$} & Distribution of occurrences (States) \\
\hline Southern Coastal Plain Blackland Prairie and Woodland & AL, GA, FL, MS, TN \\
East Gulf Coastal Plain Interior Upland Longleaf Pine Woodland & AL, FL, GA, LA, MS \\
Southwest Florida Dune and Coastal Grassland & FL \\
Eastern Serpentine Woodland & MD, NC, NY, PA, VA, GA \\
Texas Blackland Tallgrass Prairie & OK, TX \\
Texas-Louisiana Coastal Prairie & TX, LA \\
Southern Ridge and Valley Patch Prairie & GA \\
Southern Atlantic Coastal Plain Wet Pine Savanna and Flatwoods & FL, GA, SC \\
Bluegrass Savanna and Woodland & KY, OH \\
Eastern Highland Rim Prairie and Barrens & KY, TN \\
Nashville Basin Limestone Glade and Woodland & KY, TN \\
Pennyroyal Karst Plain Prairie and Barrens & KY, TN \\
Western Highland Rim Prairie and Barrens & TN \\
Arkansas Valley Prairie and Woodland & AR, KS, MO, OK, TX \\
Lower Mississippi Alluvial Plain Grand Prairie & AR \\
Ouachita Novaculite Glade and Woodland & AR \\
Ozark-Ouachita Dry Oak Woodland & AR, KS, MO \\
West Gulf Coastal Plain Nepheline Syenite Glade & AR \\
West Gulf Coastal Plain Northern Calcareous Prairie & AR, OK \\
Alabama Ketona Glade and Woodland & AL \\
\hline
\end{tabular}

on a site or small-landscape scale comparable to the effect of macroclimate on a regional scale. Sites with hotter and drier microclimates, such as south- or southwest-facing slopes, often support patches of grassland or open woodland within a matrix of closed forest. For example, shale ridge balds in the central Appalachians of Virginia are virtually always oriented south-southwest, averaging around 200 degrees. This aspect, combined with the thin, droughty soils, places these balds in direct sunlight at about 2 p.m. Apparently, little or no fire is needed for these communities to persist (Noss, 2013).

\section{Fire}

Fire is the dominant factor explaining the existence of grasslands worldwide in regions with precipitation sufficient to support forest (Bond and others, 2005). In relatively rainy regions such as the Southeast, fire can override the influence of rainfall in determining the distribution and abundance of vegetation types. Most grassland communities in the region, especially historic matrix and large-patch grasslands, depend on at least occasional fire. Some types - such as longleaf pine (Pinus palustris) savannas and Florida dry prairie - require very frequent fire, roughly every $1-3$ years, to maintain their characteristic structure, composition, and species richness. Several independent lines of evidence suggest fire has a long evolutionary history in this region, including charcoal in sediments, ancient fossils (including fossil pollen in sediment cores) of species associated with fire-prone ecosystems, high species endemism in fire-maintained ecosystems, and high incidence of fire-adaptive traits, such as thick bark, firestimulated reproduction, underground organs for carbohydrate storage, and rapid resprouting after fire (Noss, 2018).

When fire is excluded from grasslands dependent on fire, whether directly from human action or from natural causes, plant species that lack traits adapted to frequent fire invade the community and gradually assume dominance over time (Brudvig and others, 2014). Tree and shrub cover increase relative to grasses and forbs. The higher levels of fine fuels (for example, grass thatch, fallen pine needles) and small 


\section{General Model for Origin and Maintenance of Southern Grasslands}

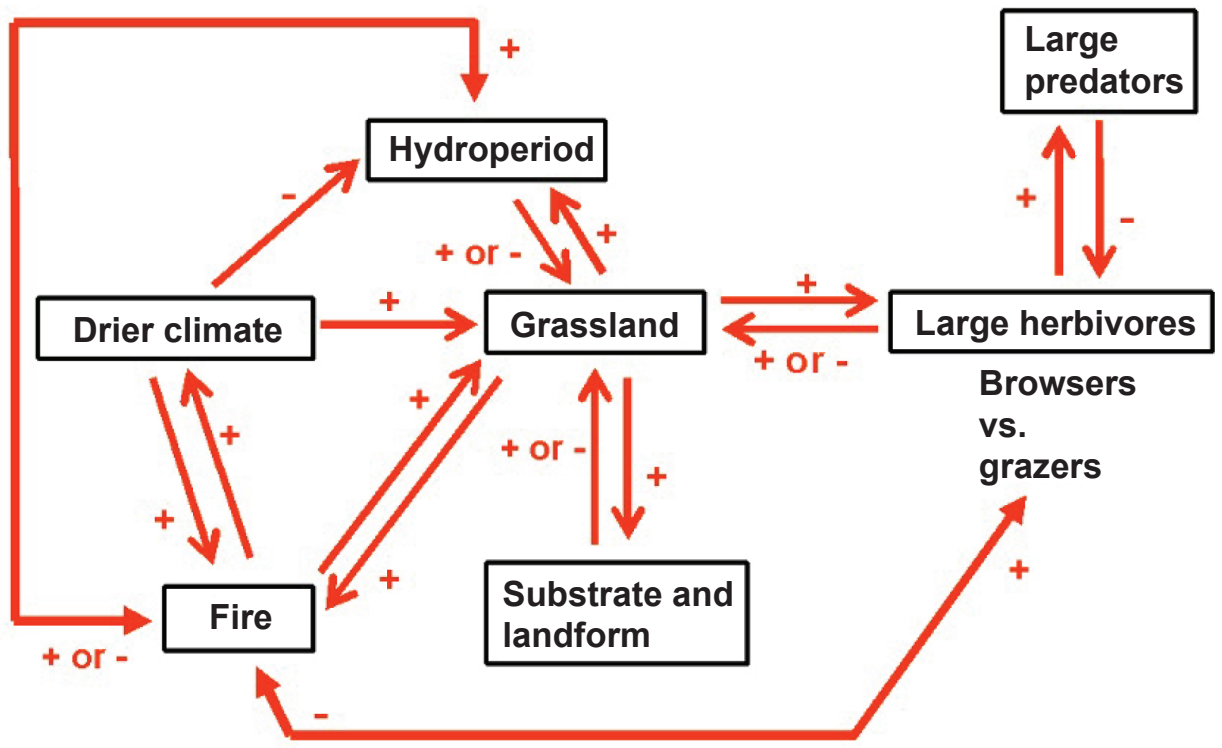

Figure 3. A general model for the origin and maintenance of southeastern grasslands. (Note: the width of these arrows and presence/absence of boxes would vary depending on the specific system.) A shift to a drier (or physiologically drier) climate favors grasses in competition with trees. Increased grassiness enhances the flammability of the system, increasing fire frequency, which in turn produces more grassland in a positive feedback relationship. Increased fire also changes climate, in that smoke suppresses cloud formation on a regional scale and reduces rainfall, producing additional positive feedback that accelerates expansion of grassland. An increase in grassland (including savannas and woodlands) favors an increase in large herbivores, including both browsers and grazers. These animals, through their feeding and tree-destroying activities, create an additional positive feedback loop that favors perpetuation of grasslands and savannas. There is likely also a role for large predators and top-down regulation in this system. Other factors, such as seasonal inundation and riverscour, are important in some systems. References in Noss (2013) and Noss (2018).

woody stems after even brief periods of fire exclusion often lead to unnaturally intense fires that can kill even fire-adapted tree species, such as thick-barked pines and oaks (Noss, 2018). If fire exclusion continues for many years, grasslands often transition to an alternative stable state such as hardwood forest, which is difficult to burn due to the paucity of flammable fine fuels. Fires then occur only during strong droughts, usually penetrating only a relatively short distance from an edge but during very severe drought sometimes resulting in standreplacing fire. After a long period of fire exclusion, restoration of the original frequent-fire community can be extremely difficult (for example, Varner and others, 2005) or nearly impossible. Canopy thinning and other mechanical methods are often required at this point to recreate a semblance of the original community.

\section{Substrate}

Unusual or physiologically stressful geology or soils often favor grassland over woody vegetation (Baskin and Baskin, 1988). Some edaphic grasslands (that is, grasslands whose existence is explained by geology or soil conditions, plus often microclimate) appear able to maintain themselves without fire or other aboveground disturbances, whereas others require at least occasional fire. Serpentine grasslands are found on ultramafic soils rich in magnesium and iron, deficient in calcium and often other essential nutrients, and typically with toxic concentrations of metals such as nickel or chromium (Kruckeberg, 1984; Tyndall and Hull, 1999). These soils create nutrient stress and physiological drought, which tends to favor grasses and drought-adapted grassland forbs 
over woody plants. In the relatively wet southeastern United States, however, trees are capable of invading serpentine soils, albeit more slowly than on more favorable soils. Fire and harsh soils in combination maintain southeastern serpentine grasslands (Noss, 2013). Many other grassland types of the Southeast-from blackland prairies on shrink-swell clay soils such as the Black Belt of Mississippi and Alabama to the Grand Prairie of Arkansas-have an edaphic component to their distribution, but still depend on fire in today's moist climate to persist.

Some types of southeastern grasslands, however, rarely or perhaps never burn. The discontinuous herbaceous cover in most glades limits connectivity of fine fuels, reducing the ability of fire to spread. In addition, many sandstone, limestone, shale, and other glades have soils so thin that they are wet only seasonally (usually winter through spring) or for brief periods after rains and become extremely dry during rain-free periods. This harsh hydroxeric condition, together with limited space for tree roots, assures a generally open canopy. When trees such as Juniperus or pines encroach, they often die off after droughts (Noss, 2013). Deep, well-drained sandy soils such as beach dunes and sandhills (former dunes from times of higher sea level) also create xeric conditions that favor grassland plants. In the case of the saline barrens of Louisiana, southern Arkansas, and eastern Texas, woody plants usually cannot survive the natric soils with high levels of exchangeable sodium except on some raised pimple mounds with less extreme conditions (Reid and others, 2010).

Most edaphic grasslands in the Southeast occur as relatively small patches, and most are insular ecosystems isolated from other patches with similar physical conditions. They can be described as naturally fragmented systems. Although the stressful environment and isolation of edaphic grasslands has reduced woody invasion and favored the evolution of many endemic species, these systems and species may be at increased risk of extinction if climate change increases moisture and temperature stress beyond their limits of toleration (Bernardo and others, 2016; Cartwright, 2019).

\section{Hydrology}

In low-lying landscapes subject to seasonal flooding, the hydroperiod (length of time a site is inundated during a year) is a strong determinant of vegetation, with long periods of inundation excluding most tree species. Plant communities at lower elevations, if only a few inches lower, usually have longer hydroperiods. Herbaceous wetlands in the Southeast with long hydroperiods include many types of marshes, which are often zoned along subtle elevational gradients. A depression marsh may be inundated almost all year in its deepest, central zone, but only for a short period in its outermost zones. Large floodplain marshes in Florida are inundated from 120 to 350 days per year (Florida Natural Areas Inventory, 2010). Artificial drainage of marshes typically leads to invasion by woody plants. Occasional ponding from precipitation events is important for maintaining vegetation heterogeneity in grasslands with microtopography such as vernal pools and many glades.
Many freshwater marshes and other wet grasslands in the Southeast depend on frequent fire to prevent tree and shrub encroachment (Noss, 2013). The marl prairies of southern Florida are generally considered wetlands and look superficially like marshes during the wet season. However, with their short hydroperiod of 2-4 months in most years, they are more accurately viewed as grasslands. Fire typically recurs in marl prairies at intervals of 2-10 years, typically at the end of the dry season in May. The Florida dry prairie, a community endemic to Florida, is not always dry. It is a hyperseasonal subtropical grassland, with its lower portions usually inundated for a few weeks of most years (Noss, 2013). The interacting stresses of fire in the late dry and early rainy season of May and June, followed by inundation later in the rainy season, exclude trees from this grassland (Platt and others, 2006).

Some herbaceous wet grasslands in the Southeast lack hydroperiods. Their soils are saturated due to groundwater seepage but are rarely or never inundated (Noss, 2013). These communities include seepage slopes and various bogs and fens across the region. Insectivorous plants such as sundews, pitcher plants, bladderworts, butterworts, and the Venus flytrap (in its limited native range) are characteristic species in these communities in the Coastal Plain.

Hydrology promotes grassland vegetation in ways other than low-intensity inundation (as in freshwater marshes) and saturation from groundwater seepage. Along rivers, periodic flooding and ice scour can maintain grassland vegetation, as powerful floods abrade and uproot woody plants. Riverscour prairies, barrens, or glades are well developed in the Southeast, including along the Potomac River near Washington, D.C., on the Allegheny Plateau of Pennsylvania and West Virginia, and in the Blue Ridge, the Ohio River Valley, the Cumberland Plateau and Interior Plateaus, and the Ouachita Mountains of Arkansas and Oklahoma. Several plant species characteristic of Midwestern tallgrass prairies, including big bluestem (Andropogon gerardii), little bluestem (Schizachyrium scoparium), Indiangrass (Sorghastrum nutans), and switchgrass (Panicum virgatum) are found in these southeastern riverscour grasslands (Noss, 2013).

Finally, salt and brackish marshes are maintained in treeless condition mostly by salinity, tidal activity, and hurricanes. These marshes, as well as seagrass beds, are not considered in detail in this report because many other Federal and State agency initiatives are presently focused on direct threats to these ecological systems from sea-level rise and increasing storm intensity.

\section{Herbivory}

Large herbivores are second only to fire as a dominant factor maintaining large areas of grassland worldwide. Grazing and browsing by a succession of large herbivores during and since the Pleistocene is the most plausible explanation for the persistence of high-elevation grassy balds in the southern Appalachians (Weigl and Knowles, 2014). Elsewhere, 
particularly in Kentucky and parts of neighboring States but as far away as northwestern Arkansas, Pleistocene and Holocene megaherbivores created and maintained a network of trails connecting the salt licks where they gathered to consume minerals. These "buffalo traces," as they were called by early white settlers who observed bison using them, extended beyond salt licks and allowed the herbivores to make seasonal migrations across a large region. The combination of grazing, browsing, and trampling by large herbivores maintained shortstature grasslands in which endemic plants such as Short's goldenrod (Solidago shortii), running buffalo-clover (Trifolium stoloniferum), and other species (like those of the mustard genus Paysonia, the bladderpods), apparently evolved. In addition, abundant fossil evidence from rivers and other sites, especially in Florida, indicate that a rich diversity of megaherbivores likely helped limit forest expansion long before and during the arrival of the first Native Americans to the southeastern Coastal Plain (Noss, 2013).

A combination of fire and grazing ("pyric herbivory") may further contribute to biodiversity in southeastern grasslands, as is documented in the Great Plains for bison as well as cattle (Davis and others, 2016; Fuhlendorf and others, 2009; Limb and others, 2011). The documented positive effects of patch-burn grazing management on biodiversity notwithstanding, livestock can have negative effects on grasslands, especially when stocking density is high. For example, heavy grazing can reduce fine fuels to the extent that surface fires become rare or extremely patchy, which often allows clones of woody plants to develop and steadily increase in height and diameter, ultimately becoming fireproof and producing an alternative stable state (Noss, 2018). An example of this phenomenon is the fire-resistant oak domes that develop after reduced fire frequency in longleaf pine sandhills in Florida (Guerin, 1993).

A complication in considering the role of large herbivores in the Southeast is that their Holocene history in the region is unclear. The Southeast had a tremendous diversity of megaherbivores from the Middle Oligocene, about 30 million years ago, through the Pleistocene (Noss, 2013; Webb, 1990). The last of the Pleistocene megaherbivores, Bison antiquus, went extinct in the Early Holocene, around 10,000 years ago. Early Spanish explorers reported modern bison (B. bison) in the Southeast in the $1500 \mathrm{~s}$, for example, on the Gulf Coast in the 1530s (location unclear) and in what is now Arkansas in 1541. However, reports from east of the Mississippi River are equivocal until the late 1600 s, when the bison population apparently increased greatly, probably in response to the pronounced decline of the Native American population and its hunting pressure (Belue, 1996; Noss, 2013). The first credible report of bison in the 17th century Southeast was in 1675, on the Florida Peninsula (Belue, 1996). The geographic source or sources of the bison recolonization or population expansion across the Southeast are unknown. The last native populations of bison in the region were eliminated on the Georgia Piedmont by 1773 and in Tennessee by 1823 (Belue, 1996).

\section{Other Disturbances and Combinations}

In addition to fire, many other disturbances damage tree canopies and promote a grass-dominated ground cover. Hurricanes, tornadoes, other windstorms, and ice storms regularly play this role in the Southeast. Although, with the exception of hurricanes, any single storm affects a relatively small area, the cumulative impacts of many such storms recurring regularly across the region would contribute to canopy openness. Canebrakes in floodplains, now reduced by more than 99 percent, may require a combination of large canopy disturbances, such as windstorms or ice storms, followed by fire or flood (Gagnon and Platt, 2008). In addition, canopy disturbance and soil fertilization by the extinct passenger pigeon probably facilitated canebrake development (Noss, 2013).

\section{Why Are Southeastern Grasslands So Biologically Diverse?}

As noted above, the grasslands of the southeastern United States are some of the most species-rich and endemicrich grasslands in the world, especially in the temperate and subtropical zones. For example, a near-record-high richness of 52 vascular plant species in 1 square meter $\left(\mathrm{m}^{2}\right)$ was recorded in a longleaf pine savanna in the Green Swamp of North Carolina (Walker and Peet, 1984), and many grassland communities across the region have species densities on a small scale nearly this high. Only some calcareous grasslands in northern Europe (for example, Estonia and Sweden) have higher plant species richness at the $1 \mathrm{~m}^{2}$ scale (Noss, 2013). On a broader scale, several regions of the Southeast are among the richest regions biologically in North America. In particular, the originally grassland-dominated Coastal Plain is now recognized as a global biodiversity hotspot because it meets the criteria of having at least 1,500 endemic plant species (it has 1,817) and losing at least 70 percent of its original vegetation (it has lost 86 percent) (Noss and others, 2015). Some 85 percent of the plants endemic to the Coastal Plain are associated with pine savannas and embedded communities such as depression wetlands (Noss and others, 2015); these are mostly herbaceous grassland plants dependent on frequent fire.

Some factors that explain the high biodiversity of southeastern grasslands are the following (Noss, 2013; Noss and others, 2015; Sorrie and Weakley, 2001):

1. Relative climatic stability for long periods of time in this unglaciated region reduced extinction rates and fostered the retention of ancient lineages (paleoendemics) and survival of recently evolved taxa (neoendemics). This is especially true for the Coastal Plain, a climatic macrorefugium buffered from climatic extremes by its proximity to consistently mild ocean currents.

2. In the Coastal Plain, sea-level fluctuations promoted allopatric speciation on high-elevation sites (intermittent islands) surrounded by ocean during high sea-level stands. Isolation by rivers and their mesic floodplains was 
also important for the evolution of grassland taxa in the Coastal Plain as well as in other regions of the Southeast.

3. Several regions contributed species to the Southeast over time, including the Great Plains, the western United States, Mexico, Central America, and the Caribbean. Collectively, southeastern grasslands are derived from Boreal (for example, grassy balds/montane outcrops), Madrean (for example, limestone barrens and glades), Neotropical (for example, pine savannas), Great Plains, and intraneous eastern North American elements (for example, eastern meadows, oak savannas). As noted earlier, a Gulf Coastal corridor of savanna and thorn scrub was an important biogeographic linkage from the Southwest to the Southeast for millions of years (Webb, 1990), as was a likely connection from the Ozarks and more southern and southwestern regions to the Interior Low Plateaus and Ohio Valley (Braun, 1955).

4. Frequent disturbance, especially by fire, wind, or large herbivores, prevents competitive exclusion and permits high species density of plants and associated animals. For example, in southeastern pine savannas, maximum plant species richness often occurs at the highest fire frequencies.

5. Southeastern grasslands form complex mosaics, often occurring in close juxtaposition with or embedded among other types of vegetation, including forests, woodlands, and various types of wetland and aquatic environments. They are associated with an impressive array of different landform types, topographic positions, hydrological regimes, bedrock geologies, and soil types and occur across an array of climatic zones. Their occurrence is often tied to particular landforms (for example, plains, plateau surfaces, ridges, bluffs), and thus they have exchanged biota or have contributions from biota that inhabit these features elsewhere.

\section{The Role of Species Status Assessments in Grassland Conservation}

The SSA process, as undertaken by the U.S. Fish and Wildlife Service (USFWS), is an analytical approach designed to provide decision makers with information on the current and projected future biological status of species listed and of candidate species for listing or proposed for listing under the ESA. The SSA process is described elsewhere (Smith and others, 2018; U.S. Fish and Wildlife Service, 2016) so we only briefly summarize it here. Essentially, an SSA is a biological risk assessment. It is a species-focused approach as opposed to the threat-focused approach that dominated USFWS species assessments in the past (Smith and others, 2018). An SSA is developed to assess each species' biological condition and viability and is intended to inform all ESA decisions, including listing and delisting, recovery planning, critical habitat designation (Smith and others, 2018), and potentially development of Habitat Conservation Plans.

Although the ideal time to develop an SSA is following receipt by the USFWS of a substantial petition to list a species as threatened or endangered (Smith and others, 2018), an SSA can be initiated at any time and is intended to be updated when new information becomes available. Among the principles the USFWS follows with an SSA are the "three Rs"-representation of all geographic or genetically distinct populations (a proxy for adaptive capacity); resiliency of populations (for example, to stochastic disturbance events or climate change); and redundancy (multiple populations conserved to spread the risk of stochastic events among multiple populations or areas) (Smith and others, 2018; U.S. Fish and Wildlife Service, 2016). Populations, in this scheme, could range from local populations to regional metapopulations. Because SSAs provide a unified, official resource for species' biological information, it is critical that they be informed by the best available science. However, research and data are often insufficient or lacking for rare plant species, invertebrates, and even some vertebrates, especially in relation to potential climate-change effects on habitat and population trajectories.

Considerable information exists for many federally listed species in the Southeast in the form of recovery plans, monitoring reports, and various other documents, but there is a considerable backlog in the preparation of SSAs. There is also concern that the most highly imperiled species are not always prioritized over less imperiled taxa. With so many species of conservation concern in the region, the workload of preparing SSAs for each species individually is proving challenging. The southeastern USFWS regional office in Atlanta carries about 60 percent of the workload of the entire U.S. endangered species program (Mike Marshall, Texas A\&M Natural Resource Institute, written commun., 2020). A major impetus for this project and report is the need to find a scientifically defensible way to make SSAs more efficient as well as more likely to achieve successful conservation outcomes.

The overwhelming workload of a species-by-species approach has strengthened the argument for an ecosystembased approach to SSAs. For example, single-species SSAs could be grouped according to shared habitat affiliations. The biological status of species is usually directly linked to the condition of the ecosystems with which they are associated. The few exceptions are mostly species threatened by introduced pathogens, competitors, or predators. As ecosystems decline in distribution, area, or condition, the species associated with them also decline, often to the point where they warrant listing under the ESA (Noss and others, 1995). This empirical fact, together with the recognition that detailed information on the vast majority of individual species is lacking, supports a "coarse filter" or ecosystem-based approach. In such an approach, a list of the ecosystems (such as NatureServe ecological systems) of a region is assembled and the status of ecosystems is systematically assessed. The logic is that by recognizing and protecting ecosystems, the vast majority of species will be protected without needing to consider each species individually (Jenkins, 1985). 
The IUCN Red List of Ecosystems project, initiated in 2014 after several years of planning (Keith and others, 2013; Keith and others, 2015; Rodríguez and others, 2011), is the major ecosystem assessment effort globally. The IUCN redlisting criteria for ecosystems include (1) rates of decline in ecosystem distribution; (2) restricted distributions with continuing declines or threats; (3) rates of environmental (abiotic) degradation; (4) rates of disruption to biotic processes; and (5) quantitative estimates of the risk of ecosystem collapse. In North America, NatureServe is leading the Red List of Ecosystems effort, applying their ecological systems classification. This work is in progress, but NatureServe has already prepared a classification and list of ecological systems, along with an ecological condition assessment — environment, key processes and interactions (dynamics), threats, and ecosystem collapse indicators-for each ecological system type in the Southeast. As noted above, this effort has already identified southeastern grasslands as the largest category of critically endangered ecosystems across North America.

An ecosystem-based approach is more cost-efficient than a species-by-species approach, in large part because many species with similar biological requirements can be addressed by the same actions. As noted by Watson and others (2020): "It is difficult to accurately assess progress towards conservation targets at the species level - a major constraint on their effectiveness. Monitoring of at-risk species is often infrequent, and numbers fluctuate naturally from year to year. Such species also tend to be elusive." Ecosystems can be more readily mapped, monitored, and managed than large numbers of species considered individually (Noss and others, 1997), albeit monitoring of community composition, structure, and health can be quite challenging. Importantly, a fundamental goal of the coarse-filter or ecosystem approach to conservation is to keep common species common and therefore limit the number of species requiring status review and listing. At-risk ecosystems, however, can serve as a leading indicator of places where additional species will likely require review. The shared or overlapping habitat requirements of multiple taxa associated with an endangered ecosystem help make SSAs more efficient because much information and analysis is shared across species.

Species of conservation concern cannot be ignored in a coarse-filter approach. A complementary fine filter can be efficiently focused on the most highly imperiled or sensitive species (which might "fall through the pores" of a coarse filter), those that play key ecological roles, and those that are reliable indicators of the quality or condition of an ecosystem. Indeed, the population status of particular indicator speciesfor example, those that are foundation species (for example, dominant, highly flammable grasses) or which are sensitive to changes in the structure or processes of an ecosystem-are often the best indicators of ecosystem condition. The Floristic Quality Index, for example, is applied at a site level on the basis of "coefficient of conservatism" scores assigned to individual species, which reflects the degree to which they are associated with high-quality examples of particular natural communities (for example, Cretini and others, 2012; Swink and Wilhelm, 1979). If most species, especially "conservative" ones, in a community are stable or improving in status, this indicates that the ecosystem is in good condition. Importantly, a robust ecosystem approach explicitly includes attention to ecological processes (for example, disturbance and recovery processes, habitat loss and fragmentation, trophic dynamics) affecting multiple species, which would not necessarily be adequately accounted for in a species-by-species approach.

To increase efficiency further, species can be organized according to their functional groups (habitat associations, life histories, guilds, limiting factors, and so on) and their specific ecosystems with which they are associated. There are currently around 120 NatureServe ecological systems that qualify as grasslands in the southeastern United States (appendix 1). The Red List of Ecosystems protocol provides for a systematic and spatially explicit assessment of ecosystem extent and level of degradation, which in turn is indicative of probable population trends of species associated with each ecosystem type. LANDFIRE has already produced maps for the biophysical setting of major ecological system types, which provide an estimate of potential/historical location and extent, using inductive modeling that correlates field-based observations of each type with mapped information on climate, landform, and soil (see Comer and others, 2018). LANDFIRE Remap (LANDFIRE, 2016) completed an update of existing vegetation type and structure for these same units using satellite imagery to provide a snapshot of current extent circa 2016. However, several grassland types of interest to our effort were too narrowly distributed to have been mapped by LANDFIRE and will require specialized mapping.

\section{Assessment of Science Needs for Southeastern Grasslands: Methods}

Grassland managers, researchers, and administrators from State and Federal agencies, nongovernmental organizations (NGOs), and universities collaboratively held a regional needs-assessment workshop at the Bridgestone Americas facility on January 22-23, 2020, in Morrison, Tennessee, to identify key science needs for the conservation of southeastern grassland ecosystems and species. The workshop, titled "Assessing the Science Needs of Southeastern Grassland Species of Conservation Concern," focused on identifying specific types of scientific information needed to support the USFWS and State agencies in the development of SSAs for grassland species listed as endangered or threatened under the ESA or under consideration for such listing.

The workshop was organized by SGI (Austin Peay State University in Clarksville, Tennessee) and the U.S. Geological Survey and physically hosted by the Bridgestone Americas corporation. Planning for the workshop-including development of background materials, agenda, and lists of participants to invite - was conducted by a steering committee (table 3 ). Thirty-nine workshop participants representing a diversity of State and Federal agencies, NGOs, and academic institutions with expertise in southeastern grasslands (table 3) were asked 
Table 3. Participants in the workshop in Morrison, Tennessee, January 22-23, 2020, "Assessing the Science Needs of Southeastern Grassland Species of Conservation Concern." Steering committee members are marked with an *.

\begin{tabular}{|c|c|}
\hline Participant name & Participant affiliation \\
\hline Daniel Adams & U.S. Fish and Wildlife Service \\
\hline Matthew Albrecht & Missouri Botanical Garden \\
\hline Jessi Allen & Atlanta Botanical Garden \\
\hline Ryan Boyles & U.S. Geological Survey \\
\hline Kyle Brazil & American Bird Conservancy \\
\hline Cooper Breeden & Southeastern Grasslands Initiative \\
\hline Geoff Call* & U.S. Fish and Wildlife Service \\
\hline Jennifer Cartwright* & U.S. Geological Survey \\
\hline Bashira Chowdhury & Auburn University \\
\hline Emily Coffey & Atlanta Botanical Garden \\
\hline Patrick Comer & NatureServe \\
\hline Todd Crabtree & Tennessee Department of Environment and Conservation \\
\hline Adam Dattilo & Tennessee Valley Authority \\
\hline Chris Doffitt & Louisiana Department of Wildlife and Fisheries \\
\hline Sam Droege & U.S. Geological Survey \\
\hline Caitlin Elam & Tennessee Department of Environment and Conservation \\
\hline Gregg Elliott* & Southeastern Grasslands Initiative \\
\hline Dwayne Estes* & Southeastern Grasslands Initiative \\
\hline David Hanni & Tennessee Department of Environment and Conservation \\
\hline JoVonn Hill & Mississippi State University \\
\hline Chuck Hunter* & U.S. Fish and Wildlife Service \\
\hline Zach Irick & Southeastern Grasslands Initiative \\
\hline Todd Jones-Farrand & U.S. Fish and Wildlife Service \\
\hline Wesley Knapp & North Carolina Natural Heritage Program \\
\hline David Lincicome & Tennessee Department of Environment and Conservation \\
\hline Tara Littlefield & Office of Kentucky Nature Preserves \\
\hline Kathy Marquart & Southeastern Grasslands Initiative \\
\hline Mike Marshall* & Texas A\&M University and U.S. Fish and Wildlife Service \\
\hline Reed Noss* & Florida Institute for Conservation Science \\
\hline Milo Pyne & NatureServe, retired \\
\hline Nicole Rankin & U.S. Fish and Wildlife Service \\
\hline Al Schotz & Auburn University \\
\hline Guenter Schuster & Eastern Kentucky University \\
\hline Jason Singhurst & Texas Parks and Wildlife Department \\
\hline Christopher Tracey & Pennsylvania Natural Heritage Program \\
\hline James Vanderhorst & West Virginia Natural Heritage Program \\
\hline Jeffrey Walck & Middle Tennessee State University \\
\hline Scott Wiggers & U.S. Fish and Wildlife Service \\
\hline Theo Witsell* & Southeastern Grasslands Initiative \\
\hline
\end{tabular}


to consider information (background material) presented in an annotated outline of this report, circulated prior to the workshop, as well as information presented by speakers early in the workshop. Participants were then asked to use their knowledge and expertise on grassland ecosystems to revise and expand the outline into the basis of this report. The rudimentary report was expanded and edited by Reed Noss into a draft manuscript, which was circulated first to primary coauthors and later to all workshop participants for comments, edits, and other contributions.

The format for the workshop included several introductory presentations followed by two half days of breakout group discussions and, finally, group reports to the entire combined group with whole-group discussion and revision of the report outline. Following introductory presentations, workshop participants were divided into five groups for breakout sessions. Breakout sessions applied a modified "World Café" approach, which is a structured conversational process for knowledge sharing in which groups of people discuss a topic at several tables, with workshop participants switching tables periodically and getting introduced to the previous discussion at their new table by a "table host," who facilitates discussion and takes notes (The World Café, 2020).

The workshop steering committee decided in advance to focus group discussions at the workshop on the science needs related to major threats to southeastern grasslands. Five categories of threats to grassland communities and species were selected for discussion: (1) habitat loss, fragmentation, and disruption of functional population connectivity; (2) climate change, especially changes in temperature and precipitation, including intensity and seasonality, and impacts on soil moisture, groundwater levels, and other ecosystem parameters; (3) changes to disturbance regimes, as influenced by climate and land-use change, extinctions, and human attitudes and behaviors; (4) invasive species (predominantly but not limited to nonnative species); and (5) localized or subregional impacts such as sea-level rise and high-elevation warming. These five themes became the topics for small-group discussions at five tables during the World Café portion of the workshop. Many other more specific topics related to these five categories of threats were also discussed at the workshop. For each of the five categories of threats, workshop participants were instructed to focus on science and information needs, such as database availability, field survey priorities, modeling and mapping needs, targeted field research (observational and experimental), as well as conservation and management needs. Thus, the World Café format generated extensive lists of science needs for conservation of southeastern grasslands in each of these five categories of major ecosystem threats. In addition, results from a preworkshop survey of grassland experts were synthesized to provide insights about opportunities and challenges to grassland conservation (appendix 2). This survey represented perspectives not only of workshop participants, but also from a few grassland experts who were unable to attend the workshop in person.

\section{Results: Science and Information Needed To Support Conservation of Southeastern Grasslands}

For the most part, threats to southeastern grasslands and their associated species are processes that disrupt the factors, described earlier, that have been responsible for the origin and maintenance of grassland communities in the region, and which have produced such extraordinarily high levels of species richness and endemism. The ultimate threats to grasslands and other ecosystems in the Southeast are unsustainably high human population growth and associated urban expansion (Terando and others, 2014). Wildlife and conservation agencies are not able to address these ultimate threats but must instead focus on specific proximal threats that follow from the ultimate threats and which are discussed in this section.

Below we summarize group discussions on the five categories of threats identified in the preceding section. It is important to note that the results below, inasmuch as they are derived from breakout group discussions, represent ideas, problems, hypotheses, and questions to be addressed by future research and monitoring. They report science needs, but do not provide answers. Group discussions from the workshop only occasionally included specific references to published literature; hence, the results presented below (after introductory material in each section) are presented as "bullets" and are intentionally sparsely referenced.

\section{Habitat Loss, Fragmentation, and Disruption of Functional Population Connectivity}

The loss and fragmentation of natural habitat is accepted by most conservation biologists as the leading threat to biodiversity (Fletcher and others, 2018; Haddad and others, 2015; Noss and others, 2006a), although some detractors argue that habitat loss is the real problem and that fragmentation per se often has positive effects for biodiversity (Fahrig, 2017). Much of the difference in opinion has to do with what kinds of organisms are being studied, the type of natural community and its landscape context, and what kinds of changes are considered as impacts of fragmentation (for example, those who argue fragmentation is not a problem usually ignore edge effects).

Fragmentation is clearly more of a problem for some types of natural communities and species than for others. Small patch communities, such as many edaphic grasslands, are naturally small and isolated from other occurrences of the same community (ecological system) type, that is, they are naturally fragmented, and their species are presumably adapted to this condition. If properly buffered and managed, these communities can be adequately conserved within relatively small and isolated reserves. Nevertheless, improving the permeability of the matrix, for example, to facilitate 
movement by pollinators and dispersers, is often a legitimate management goal. In general, the value of small reserves is impressive and has not received enough attention from conservationists (Wintle and others, 2018). Grasslands and other communities that are naturally matrix or large-patch communities typically show greater negative impacts of anthropogenic fragmentation, especially for area-sensitive animal species with large home ranges and for any species sensitive to edge effects (Noss and others, 2006a).

Connectivity, in many respects, is the antithesis of fragmentation. A well-connected network of conservation areas can create a whole greater than the sum of its parts, in that whereas no single reserve may provide for a viable population of a target species, an interconnected network of reserves might do so. The kind of connectivity that is important here is functional connectivity, defined for plants as "the effective dispersal of propagules or pollen among habitat patches in a landscape" (Auffret and others, 2017), rather than simply the presence of what appears to humans as a suitable corridor between one site and another. Moreover, in conservation planning, it may be important to emphasize suitable functional connectivity for species that are vulnerable to habitat fragmentation, as not all species are particularly vulnerable (Beier and Noss, 1998). Fragmentation-sensitive species are typically associated with large patch or matrix communities. There is no need to try to connect sites with communities that are naturally isolated, and doing so could disrupt local adaptations (although, with climate change, assisted colonization between such sites might be warranted in some cases).

The workgroups identified the following important questions and research needs with respect to habitat loss, fragmentation, and connectivity:

\section{Mapping and Modeling}

- Urban sprawl and development are increasing threats for southeastern grasslands, prompting a need to identify, through mapping and modeling, which grassland communities are most subject to the effects of urbanization. For example, condominium development in coastal Alabama has fragmented habitat for populations of rare bees associated with sand-dune grassland plant species.

- There is a need to continue to improve maps of historic and current distributions of all southeastern grassland types and determine extents and rates of grassland loss in order to prioritize communities and sites for conservation.

- A better understanding is needed of how fragmented grasslands that are not publicly owned align with publicly owned lands. Although this is a relatively straightforward geographic information system analysis, achieving high accuracy would be time consuming.

\section{Scientific Research}

- Most SSAs do not explicitly consider data for connectivity and fragmentation issues. These considerations could be incorporated into SSAs as appropriate.

- Improved understanding of ecological dynamics is needed for naturally fragmented (patchy) grassland types embedded within a dissimilar matrix, such as most edaphic grasslands, along with improved mapping and modeling applications to detect these small-patch communities. It is important to appreciate that the matrix for many small-patch grasslands has changed over time; for example, isolated glades that were once surrounded by savanna/woodland are now surrounded by closed forest or urban developments, which are likely less permeable to movement of grassland species.

- Research is needed to determine what regions have large percentages of their grassland biota relegated to powerline corridors or other types of transportation or energy corridors. There may be a need to determine the future impacts that changing to different energy systems (for example, wireless technology) will have on grasslands dependent species on powerline corridors, for example.

- Research is needed on what woody vegetation management activities are most compatible with conserving grassland species in rights-of-way. There is a need to identify specific best management practices in this context.

- Research is needed on the effects and suitability of different management practices and frequencies on patches of varying sizes.

- There is a conservation and management need to determine the minimum grassland patch size needed to support viable populations of grassland dependent species, such as the northern bobwhite (quail) in various regions of the Southeast.

- It will be important to identify which grassland communities are likely to be adversely impacted by afforestation (tree planting) practices in coming years, as a means to increase carbon sequestration, for which grasslands may be more reliable (see below under "Climate Change").

- There is a need to identify which grassland communities are most threatened by cultural changes in land management such as increased mowing and herbicide application and changes in wildlife management, such as increased planting of wildlife food plots.

- In the context of grassland fragmentation, there is a need to know the effects of inbreeding and low population genetic diversity of both imperiled and common species in these systems. 
- What is the success rate for dispersal of various species among patches of fragmented grasslands? Managers also need to know how native forest versus other land uses (for example, loblolly pine plantations) affects native pollinator diversity and subsequent gene flow among fragmented grasslands.

- A much better understanding of the mutualistic relationships between insect pollinators and grassland plants is required in light of fragmentation. Similarly, increased understanding is needed about how fragmentation may disrupt other plant-insect interactions, such as obligate herbivory by conservative insects, as well as predation and parasitism more broadly. For example, how does fragmentation of gopher tortoise (Gopherus polyphemus) populations affect the obligate gopher tortoise tick (Amblyomma tuberculatum), which is rarer than its host and is not found in every population of its host?

- Better understanding is needed of seed dispersal mechanisms and distances for dispersal (gene flow) among grassland species.

- More data are needed, across organismal groups, on effects of selective thinning applications in savannas and woodlands.

- There is a need for research on edge effects and road effects (for example, salt spray) in southeastern grasslands and interactions with the associated matrix communities.

- More research is needed on the effects of grassland conversion to fescue pastures.

- In general, southeastern grassland conservation could benefit from an expanded focus on other taxonomic groups beyond plants. For example, more data are needed on bird and insect species composition and diversity in seminatural grasslands such as managed "semi-improved" pastures. These are preferred habitats for some native species.

- Improved data are needed on the effects of grazing, burning, and mowing practices in seminatural and natural grasslands to determine which practice (or combination of practices) would be most appropriate.

- Is wind or solar energy infrastructure a threat to southeastern grasslands, and if so, how? Conversely, what are the potential benefits? For example, could wind or solar farms be managed to create new grassland habitat or provide pollinator corridors?

- Basic ecological research is needed on urban grasslands.

- We need a better understanding of hydrological needs for species associated with both wet and dry grasslands. In general, there is an information gap for hydrological data for nearly all types of grassland communities.
- There is a need to develop and validate Floristic Quality Assessments (FQAs) by State, ecoregion, and specific grassland community types. FQAs could be a useful tool to study the effects of different types and levels of fragmentation, including road effects and hydrologic alteration.

- Can FQA data be used to discern floristic responses to fragmentation, including how sensitive various grassland communities are to fragmentation?

\section{Conservation Planning}

- Virtually all grassland communities in the Southeast are already highly affected by habitat loss and fragmentation. There is a need to determine which of these grasslands are of highest conservation concern and plan for their protection.

- FQAs can also assist conservation planning by identifying sites that contain high native species richness and many conservative species. This is being done for blackland prairie remnants in Texas.

- Future conservation of at-risk grassland plant species would benefit from active and strategic seed collection within all known remnants. Seed collection should follow established protocols, such as those developed by the Seeds of Success program (matrix or common species) and the Center for Plant Conservation (rare species), which maximize genetic diversity, consider ecotypic variation, and ensure that collections do not negatively impact source populations. Then, information on species-seed availability and composition can be used to design seed mixes that match natural communities by starting with low-diversity mixes and working up to more diverse mixtures.

- An important issue in conservation planning is managing data sensitivity (that is, locations of rare or threatened species, which are kept private to protect those species) to support the SSA process within the institutional constraints of the USFWS.

\section{Restoration and Management}

- Restoring a more permeable (to species movement) landscape matrix surrounding small patch grasslands is a high priority in many cases, for example, where the matrix has shifted from open woodland to closed forest or urban development.

- Improved understanding of the value and feasibility of restoring grasslands that have been lost to agricultural conversion is also needed. For example, areas such as the Grand Prairie of Arkansas and the loess prairies 
of western Kentucky have declined by an estimated 99.99 percent. Are there enough remnant populations of grassland-dependent plants to reconstruct these communities?

- Many species that are being petitioned for listing under the ESA in the Southeast are found in communities embedded within a longleaf pine matrix. How do we increase connectivity of embedded habitats in matrix communities to address those species' needs? Or is connectivity already sufficient for species in these naturally isolated communities?

- The management of powerline and other open rights-ofway, such as gas pipelines and roadsides, will be critical to conservation of many grassland species. Loblolly pine plantations and closed forests restrict grassland habitat to rights-of-way across much of the Southeast. These rights-of-way can serve as critical dispersal corridors for native grassland species or alternately as invasion corridors for nonnative or native weedy species, depending in large part on how they are managed.

- Are options available to connect the sale of wood harvested for restoration thinning or other timber removal from grasslands to other grassland restoration activities?

\section{Education and Public Outreach}

- Future efforts in conservation of southeastern grasslands need to include a human dimension or sociological component. For example, grassland restoration could be coupled with restoration of historical sites such as Civil War battlefields.

- Outreach to wildlife managers and hunters is needed to reduce practices, such as planting of food plots and management for artificial edge effects, that degrade natural grasslands. Opportunities should be sought for mutual benefits of grassland restoration to hunters and other recreationists.

- Improved maps of historical grasslands can serve as effective outreach tools to use when discussing potential conservation and restoration of grasslands with property owners. This may be especially useful when communicating with multiple landowners.

- Could urban sprawl have positive benefits for grassland conservation due to increased volunteer engagement, which may help bring more awareness of grassland conservation issues?

- Better tools are required to promote communication between forest advocacy groups and grassland conservationists to address alternative viewpoints.
- Wetland conversion is a major threat to certain grassland types across the region. For example, on the Cumberland Plateau of Tennessee most bogs were converted to ponds in the 1940s when mechanized machinery was introduced. Altogether some 60 percent of wetlands in Tennessee were lost from 1780 through the 1980s (Dahl, 1990). More communication and education are needed on the consequences that could result from the conversion of remaining bogs and other wetlands into wildlife or livestock ponds.

- Education is needed on the importance of beavers as ecosystem engineers of wetland systems. Many conservative and imperiled species (for example, the federally endangered Mitchell's satyr, Neonympha mitchelli) depend on beaver-created grassy wetlands such as sedge meadows. Beavers are often killed to protect timber, even on public lands.

\section{Climate Change}

Climate change has emerged as a profound and complicated proximal threat to grasslands and their native species, just as it has to the better-studied forests and other ecosystems (for example, wetlands, streams, coastal, marine) of eastern North America. Forests, however, have received considerably more attention than grasslands with respect to their potential responses to climate change and the various mitigation, conservation, and adaptation options (for example, Bonan, 2008; Dale and others, 2001; Noss, 2001). In contrast, studies of grasslands and climate change have been mostly limited to basic research on productivity, decomposition, soil carbon, and other ecosystem properties, with little attention to conservation or management. Moreover, planting trees (afforestation) to capture carbon has become a major threat to many types of grasslands worldwide (Noss and Veldman, 2019; Veldman and others, 2015). Ironically, recent research shows that grasslands are a more secure carbon sink than forests during a time of increasing temperature, drought, and wildfire because they store most of their carbon securely below ground (Dass and others, 2018). Moreover, it is reasonable to predict that the type of vegetation that is native to a region, landscape, or site will function better at capturing and storing carbon than will introduced vegetation.

The 4th National Climate Assessment (NCA4) Volume I (USGCRP, 2017) and Volume II (USGCRP, 2018) provide the most recent authoritative assessment of climate-change science, impacts, and risks to the United States. NCA4 provides key summaries on scientific findings for the Southeast that impact grassland ecosystems, including high confidence in the following:

- Temperatures are warming and will continue to warm. This is observed in several trends of historical climate data, including increasing average temperatures, increases in the length of the frost-free season, and an 
increase in the number of warm nights (fig. 4). Plant hardiness zones, largely defined by the average coldest temperature in any given year, are shifting northward (fig. 5). The number of very warm days is expected to increase, while the number of cold days is expected to decrease. These trends are projected to continue under future scenarios with increasing greenhouse gas concentrations. As temperatures increase, evaporation and plant transpiration increases, potentially decreasing plant available water if precipitation is insufficient.

- Oceans are warming and sea level is rising. Rising sea levels create more frequent inundation of coastal marsh systems. Warmer waters in the Gulf of Mexico, Caribbean, and south Atlantic Ocean lead to more evaporation and subsequent increases in atmospheric moisture over the Southeast. Warmer waters also support the development of more intense hurricanes.

- Precipitation events are more intense. Extreme rainfall events are expected to continue becoming more frequent (fig. 6). However, the potential changes to future average total seasonal precipitation is less certain because the frequency of dry days may also increase.

- Extreme events are very likely to induce ecological transformations. With increasing temperatures, drought is also expected to become more frequent and severe. Changing climate will also affect fire regimes, affecting both the frequency of wildfire occurrence and the current practices of prescribed fire for ecosystem management. Stronger hurricanes will increase disturbances to both coastal marshes and interior forests.

Despite these predicted trends and their high confidence, the threats posed by climate change to southeastern grasslands and grassland species still are not well understood (Cartwright and Wolfe, 2016), nor are the potential adaptation options. Species inhabiting mountain ranges can often survive periods of climatic oscillation by dispersing relatively short distances along elevational gradients or from one slope aspect to another, that is, by shifting along steep temperature gradients and between contrasting microhabitats. Therefore, mountain ranges have often served as climatic macrorefugia with high levels of endemism, and some researchers expect this trend to continue (Harrison and Noss, 2017; Jansson, 2003). Potential climatic microrefugia such as grassy balds, outcrops, northfacing slopes, valley bottoms, coves, sinks, and seeps also are important in mountains (Dobrowski, 2011). Unsurprisingly, the Southern Appalachians are a center of narrow-range species richness (endemism) (fig. 1), which may reflect, in part, historic climatic microrefugia.

Coastal regions, even when flat, may serve as climatic macrorefugia and hotspots of endemism if their climate is regulated by consistently mild ocean currents (Harrison and Noss, 2017). This is the case for the North American Coastal Plain, especially its southeastern section (Donders and others, 2011; Noss and others, 2015). Still, the question of whether climatic macrorefugia and microrefugia that functioned in the past will continue to function effectively in the future is a topic of considerable debate in ecology (Cartwright, 2019; Denney and others, 2020; Hannah and others, 2014; Harrison and Noss, 2017), with some researchers concluding that past climatic refugia will be "hospices for biodiversity in the Anthropocene" due to extreme future temperature increases (Brown and others, 2020).

Some of the most vulnerable grasslands in the southeastern United States are those distributed in low-lying coastal areas subject to direct impacts of sea-level rise, increased salinity of soils and shallow groundwater, and other stressors (Noss, 2011; 2013). These communities include the pine rocklands and cactus barrens of the southern Florida Peninsula and the Florida Keys, marl prairies of southern Florida, the coastal prairies of Texas and Louisiana (which have declined by approximately 99 percent; Noss and others, 1995), Tamaulipan thornscrub in South Texas, beach dune communities on both the Atlantic coast and Gulf of Mexico, the small remnants of the Hempstead Plains grasslands on Long Island, and a variety of other coastal grasslands including salt, brackish, and freshwater tidal marshes. These coastal and nearcoastal grasslands are being subjected to the combined stresses of rapid sea-level rise, freshwater draw-down, salinization of ground and surface waters, coastal development (for example, condominiums and hotels), pollution, increasing hurricane intensity, loss of protective mangrove swamps, and many other factors. Indeed, most grassland communities in the Southeast are suffering from multiple stresses, which often act synergistically and complicate conservation and restoration efforts.

Because many species in an ecological community are projected to reach their limits of toleration to climate change almost simultaneously, disruptions to communities will likely be abrupt (Trisos and others, 2020). Nevertheless, a possible source of optimism for southeastern grasslands is that projected climate change over this century will potentially be more favorable to grasslands than to forests. A hotter and physiologically drier climate, or one with a higher frequency of severe droughts (as predicted and already apparent), generally favors grasses over woody plants. This is well documented in paleoecology for the Southeast and globally, for various dry periods from the Late Miocene to the mid-Holocene (Beerling, 2007; Noss, 2013). Even with increases in precipitation, which may happen in much of the Southeast, a warmer climate will increase evapotranspiration and probably reduce soil moisture available to plants. As moisture stress increases, grasses are expected to be favored over woody plants. Warmer temperatures also favor $\mathrm{C}_{4}$ grasses (Morgan and others, 2011), the dominant flammable grasses of southeastern grasslands. Increased grassiness promotes more fire, which in turn produces more grassland in a positive feedback relationship (Pausas and Keeley, 2009). On the other hand, all else being equal, increasing atmospheric $\mathrm{CO}_{2}$ concentrations will benefit woody plants and other $\mathrm{C}_{3}$ species over $\mathrm{C}_{4}$ grasses, possibly to the extent that woody plants escape control by fire (Midgley and Bond, 2015). Above some threshold of moisture stress, however, $\mathrm{C}_{4}$ grasses may prosper even in the presence of much higher levels of atmospheric $\mathrm{CO}_{2}$ (Noss, 2018). 
Higher scenario (RCP8.5)
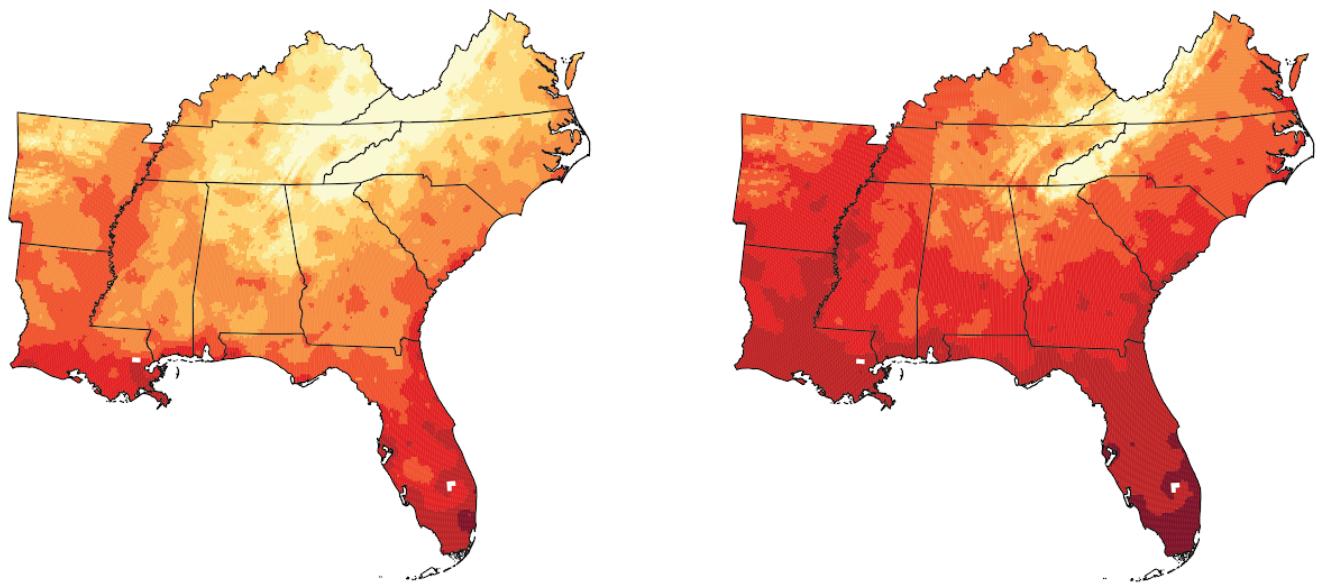

Lower scenario (RCP4.5)
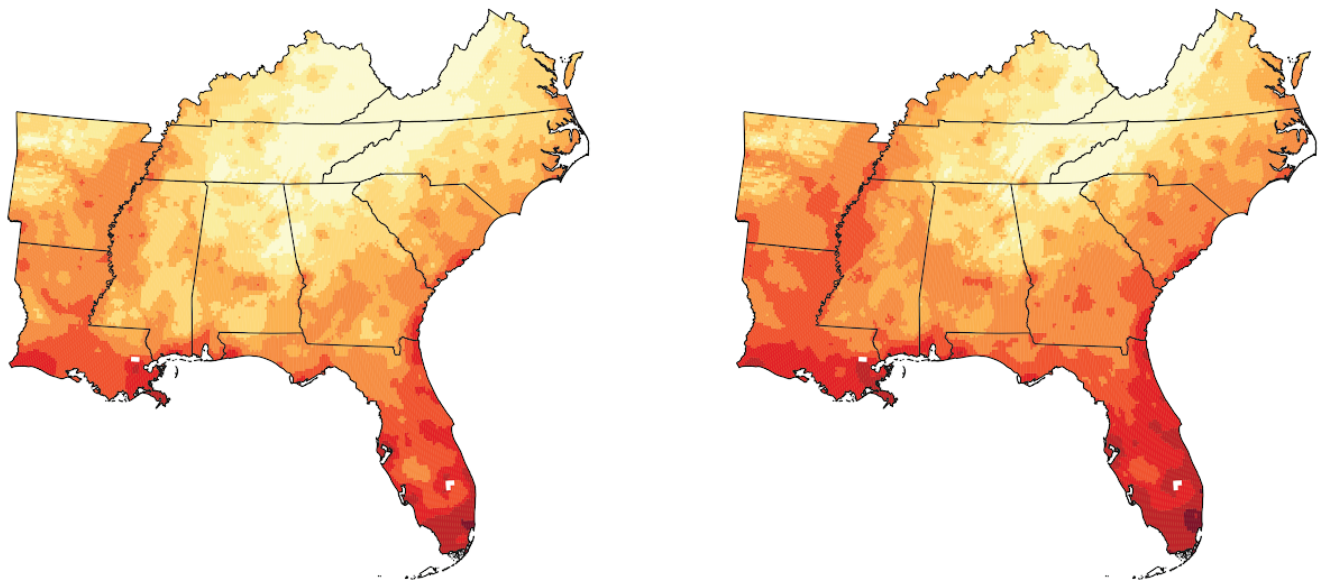

Number of nights with a minimum temperature greater than $75^{\circ} \mathrm{F}$

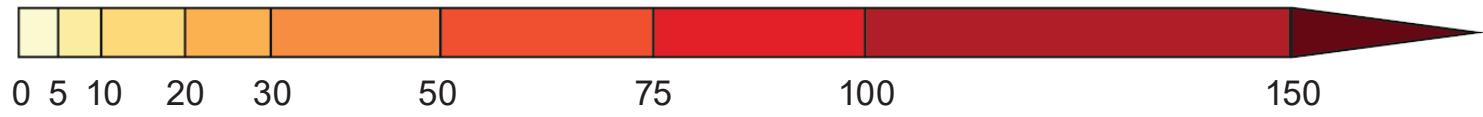

Figure 4. Projections for the number of warm nights, reproduced from U.S. Global Change Research Program (USGCRP; 2018, figure 19.5). "The maps show the projected number of warm nights (days with minimum temperatures above 75 [degrees Fahrenheit] ${ }^{\circ} \mathrm{F}$ ) per year in the Southeast for the mid-21st century (left; 2036-2065) and the late 21st century (right; 2070-2099) under a higher scenario (RCP8.5; top row) and a lower scenario (RCP4.5; bottom row)." 
Historical (1976-2005)

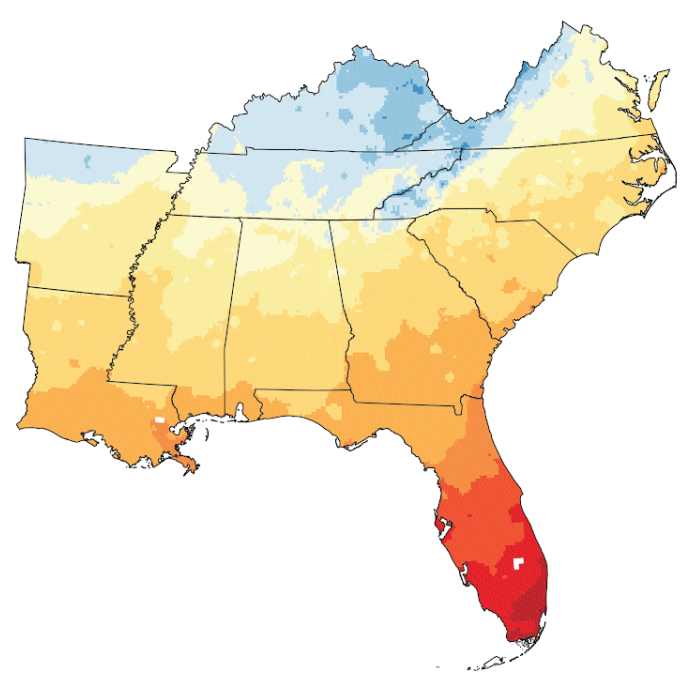

Higher scenario

(RCP8.5; 2070-2099)

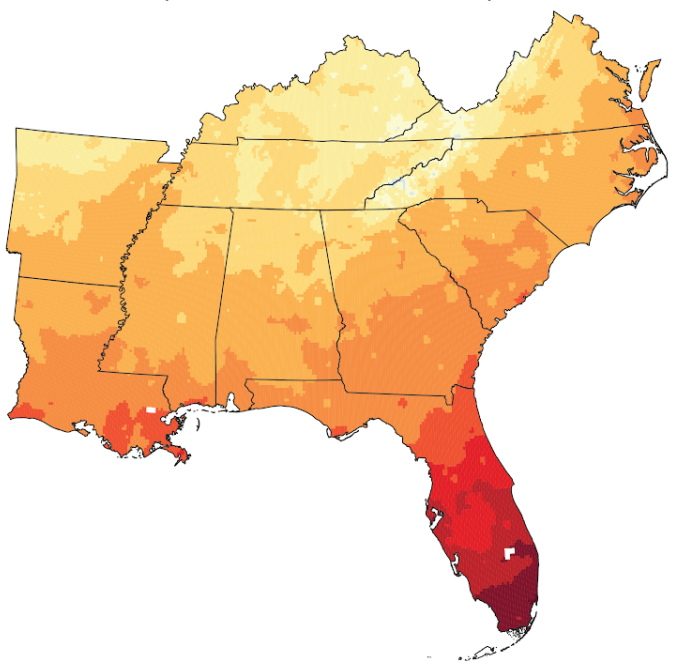

USDA plant hardiness zone

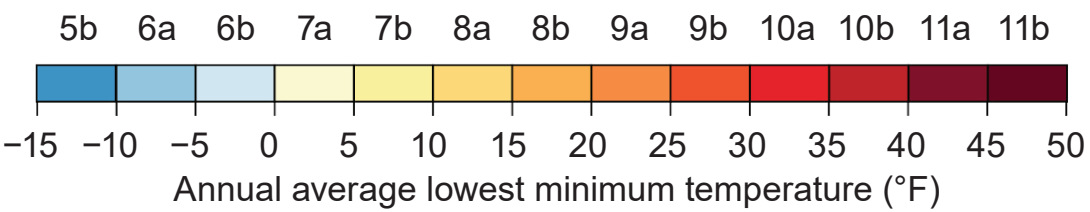

Figure 5. Shifts in plant hardiness zones, reproduced from U.S. Global Change Research Program (USGCRP; 2018, figure 19.15). "Increasing winter temperatures are expected to result in a northward shift of the zones conducive to growing various types of plants, known as plant hardiness zones. These maps show the mean projected changes in the plant hardiness zones, as defined by the U.S. Department of Agriculture (USDA), by the late 21st century (2070-2099) under a higher scenario (RCP8.5). The USDA plant hardiness zones are based on the average lowest minimum temperature for the year, divided into increments of 5 [degrees Fahrenheit] ${ }^{\circ} \mathrm{F}$. Sources: NOAA NCEI and CICS-NC."

Days with precipitation above 3 inches (1900-2016)

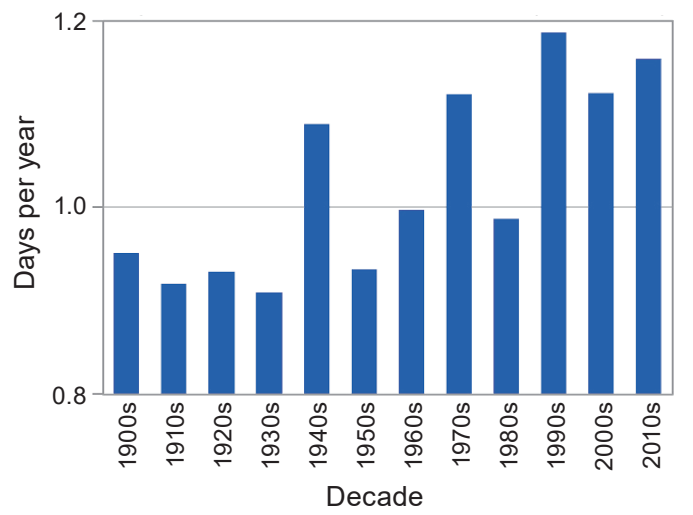

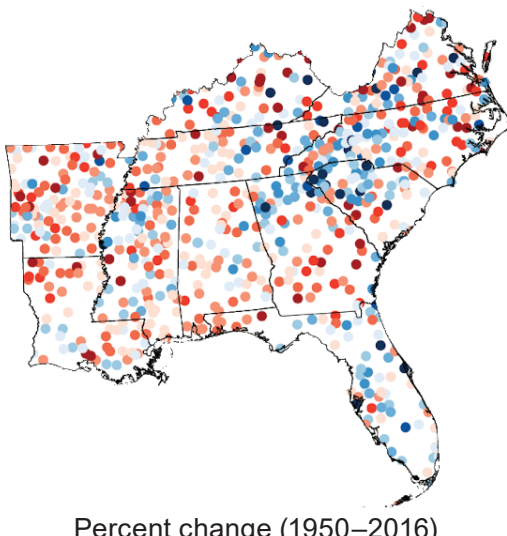

Percent change (1950-2016)

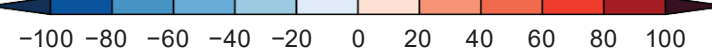

Figure 6. Trends in days with heavy precipitation, reproduced from U.S. Global Change Research Program (USGCRP; 2018, figure 19.3). “The figure shows variability and change in (left) the annual number of days with precipitation greater than 3 inches (1900-2016) averaged over the Southeast by decade and (right) individual station trends (1950-2016)." 
Climate envelope models are a popular method of projecting vegetation change in response to climate change. However, climate-vegetation models carry considerable uncertainty and some of the most commonly cited models (for example, Karl and others, 2009) are unreliable and make implausible projections of vegetation change. Some models do not even portray current vegetation correctly. For example, one recent model (Grimm and others, 2013) incorrectly shows the 1961-90 natural vegetation of the Coastal Plain as predominantly temperate mixed forest and the Florida Peninsula as temperate broadleaf forest, reflecting an old myth about the "climax" vegetation of the region, which has been rebutted since the 1960s and is now discredited (Davis, 1967; Myers and Ewel, 1990; Noss and others, 2015).

Paleoecological data show that pine savanna (probably largely longleaf pine or its antecedents) in the Coastal Plain is not only the dominant or matrix vegetation under the modern climate; it is also an ancient ecosystem, likely persisting through climatic fluctuations for millions of years, though varying in dominance in a cyclic fashion (Graham, 1999; Grimm and others, 2006; Noss, 2013). Analyses of fossil pollen from lake cores spanning the last 61,000 years in Florida show that pine and oak cycled in abundance asynchronously with each other, but with both taxa remaining common throughout this period and the overall vegetation similar to that of today (Grimm and others, 2006). The longleaf pine ecosystem is considered by most ecologists to be extremely resilient to climate change. As noted by Costanza and others (2015): “...in part because longleaf pine trees are tolerant of drought and heat stress (Samuelson and others, 2012), most climate envelope models agree that longleaf pine may become more dominant across its range, and its range may expand northward (Prasad and others, 2007). Therefore, promoting establishment of the ecosystem may facilitate climate-change adaptation... ."

Changes to disturbance regimes caused by changes in climate or land use could create rapid transitions in vegetation. None of the widely used climate-vegetation models account for the possibility of relatively rapid regime shifts (state changes) from closed forest to a woodland-grassland continuum in the Southeast. Such regime shifts have occurred in the past, driven by strong positive feedback loops between flammable vegetation and fire, and could potentially occur again (Noss, 2018; Pausas and Keeley, 2009), for example, in former savanna landscapes now dominated by closed forest as a consequence of long-term fire exclusion. Changes in plant tissue combustibility and fire activity are not among the variables directly included in most climate-vegetation models for the Southeast. Sea-level rise is also contributing to regime shifts, for example, loss of coastal forest and replacement by high marsh in the Big Bend region of Florida's Gulf Coast.

Increased fire activity, size and severity of fires, and tree mortality in response to warmer temperatures and increased drought duration are already well documented for western forests (Abatzoglou and Williams, 2016; Adams and others, 2017; Westerling and others, 2006). In the Southwest, severe fires in some landscapes appear to produce a state change from ponderosa pine (Pinus ponderosa) forest or woodland to shrubland or grassland (Haire and McGarigal, 2010; Savage and Mast, 2005). These types of change are not yet occurring in the Southeast, but a prolonged (multiple decades to centuries) shift to a hotter, drier climate could produce such effects, especially if ignition sources remain abundant. Significantly, the frequency of lightning strikes is predicted to increase over this century. A recent model projects an increase in cloud-toground lightning strikes in the United States of 12 percent per degree Celsius of warming, an approximately 50 percent increase over the 21 st century (Romps and others, 2014). Combined with warmer temperatures, higher rates of evapotranspiration, and drier fuels due to increased drought, more lightning strikes will produce more fires.

Although future climate may be more conducive than the present climate to fire and grasslands, this will not necessarily produce more grassland on the landscapes of the Southeast. Fire regimes in the Southeast today are primarily controlled by fire suppression, and suppression efforts can be expected to intensify if fire activity increases. Nevertheless, given the relatively large patches of fire-prone vegetation still remaining, especially in the Coastal Plain, and the currently highest lightning strike frequency in North America north of Mexico, wildfire remains common in the Southeast and escalating rates of wildfire will be challenging to control (Noss, 2018). Moreover, ecologists and land managers increasingly view "managed wildfire" as beneficial in reducing the fire deficit in the United States (Noss and others, 2006b; Ryan and others, 2013), albeit this view is more prevalent in the West and far North and is only beginning to develop in the Southeast.

Despite the possibility of grassland expansion with modern climate change, there is reason to be concerned about the fate of southeastern grassland species and communities over coming decades and centuries. For one, climate change is not occurring across natural, connected landscapes, but rather across landscapes that have been highly fragmented and degraded by human activities. Species that once would have been able to track shifting climate regimes by dispersing across landscapes are now restricted to fragments of natural or seminatural habitat, surrounded by development, agriculture, pine plantations, ranchland, or closed-canopy forests that have replaced formerly open savannas and woodlands. In addition, many invasive nonnative species may fare better than native species under future climate scenarios, though outcomes are uncertain (Hellmann and others, 2008). Invasive exotic species tend to have high dispersal capacity, which explains why the ratio of exotic to native grasses in a community is positively associated with the velocity of past climate change, that is, the rate at which species must move to keep pace with changing climate conditions (Dukes and Mooney, 1999). As the velocity of climate change continues to increase due to anthropogenic emissions, surprises are likely as species from other regions appear in southeastern grasslands and increase in population size relative to native species. In general, we can expect responses of invasive species to climate change to be highly individualistic, as shown for global insect pests (Lehmann and others, 2020). 
Finally, hotter and drier conditions, which could favor species in fire-dependent grasslands, may not favor some components of edaphic grasslands. These systems are already characterized by stressful microclimates (for example, exceptionally dry soil conditions in summer), so increases in stress related to climate change may push some populations in edaphic grasslands beyond a threshold of viability (Bernardo and others, 2016; Cartwright, 2019). On the other hand, some physically controlled and anchored-in-place communities are out of equilibrium with the regional climate, controlled more by local microclimate and geology and therefore serving as potential microrefugia during climate change (Noss, 2013). Karstic depressions (sinkholes), shaded cliff faces, and similarly moist, sheltered environments hold promise as microrefugia (for example, Bátori and others, 2017), though not likely for many grassland species. As shown for the high-elevation southern Appalachian plant spreading avens (Geum radiatum), which inhabits rock outcrops, cliffs, and some grassy balds, current microclimatic refugia may not function under projected climate change (Ulrey and others, 2016).

Workshop participants identified a number of critical research questions and science needs for southeastern grassland species and communities in relation to climate change. Below are some of the most important:

\section{Climate Effects on Distribution and Dispersal}

- What is the role of climate in shaping historical and current grassland distributions and geography?

- What are the climate factors that explain why a given grassland species assemblage occurs where it does (for example, interactions of climate with soils, geology, and disturbance)?

- What is the relative importance of climate versus dispersal limitation in explaining the species composition of modern and projected future grassland communities?

- There is a need to identify grassland systems - and their specific locations - that will not be able to shift their locations due to restrictions to specific soil types, geologic formations, hydrologic settings (for example, seepages), or physical processes. These "anchored-inplace" communities include grasslands associated with riverscour, karstic depressions, cliffs, glades, seeps, fens, barrens, coastal dunes, and marl prairie, among others. Could maps of such immobile systems be interfaced with climate projections to predict vulnerability for these ecosystems and their endemic species?

- Could we also (conversely) map grasslands that have greater capacity to move and track changing climate conditions? Grasslands maintained by fire, for example, often are not strictly associated with particular substrates. Increased connectivity of such systems (for example, through north-south oriented utility rightsof-way managed as grasslands) may promote adaptive dispersal of grassland species along climatic gradients.

- What are the climatic mechanisms that cause a species to disappear from an area? Possible factors, which may differ by species, include extremes in minimum or maximum temperatures, seasonal changes in soil moisture, and competition from other species that are favored under new climates.

- For many plant species, dispersal distances and rates are unknown, including their abilities for island hopping (moving from one habitat patch to another). This type of information is vital for understanding migration rates with climate change. Some general insights could be gained by grouping plant species by dispersal mode (for example, wind, animal, water, gravity, and so on).

- Are the climatic niche breadths of some southeastern grassland species greater than what they experience in their current range? If so, they may be less vulnerable to climate change.

- Also informative are studies looking at abilities of species or ecotypes to shift or migrate latitudinally or upslope (for example, reciprocal transplant experiments). Some studies (for example, Bell and others, 2014) show loss of species at higher elevations, whereas lower-elevation species are more flexible and able to colonize upslope.

\section{Role of Physiology and Phenology in Shaping Species Responses to Climate Change}

- For species of conservation concern, what are the most important physiological thresholds that determine population viability, and how will these change under climate change? Examples of potential threshold phenomena include cold tolerance, heat tolerance, inundation tolerance, salt tolerance, germination requirements, and drought tolerance. All of these physiological thresholds are likely tied to different stages in life history. Some stages may be particularly important (for example, seedling establishment may be a stronger limiting factor for population viability than germination; Walck and others, 2011). Example questions include the following: What are the temperature ranges (normal and extreme) under which germination occurs? How will extreme rainfall events interspersed with extreme droughts influence seedling establishment?

- Can we group species and then identify "model species" for each group to facilitate physiology research? Options for grouping species include functional groups, life-history characteristics, reproductive 
strategies, phylogenetic groups, habitat requirements, dispersal mode, and establishment mode. It should be noted, however, that model species may be problematic for conservation of rare species, which often have traits specialized for their habitat that differ from those in common species typically selected as model species. Nevertheless, there may be promise in modeling distributions of common species to predict distributions of rare species with which they are associated.

- Types of studies needed on physiology include the following: (1) lab studies of germination, seedling establishment, and other life-history stages; (2) field manipulative studies (for example, rainfall exclusion, supplemental watering, open-top chambers); (3) combined field-lab studies (for example, episodically bringing seedlings inside in winter to simulate cold-warm winter oscillation effects on survival); and (4) modeling studies linking physiological thresholds to climate projections.

- How will climate change affect predator-prey relationships? Warmer temperatures may force prey to feed at times or in areas they typically do not, potentially exposing them to greater predation risk.

- How will abiotic factors related to climate change affect pollination of plants? How will factors such as increasing temperatures affect the plant reproductive niche?

- Increasing levels of atmospheric $\mathrm{CO}_{2}$ may promote growth of trees and other plants utilizing the $\mathrm{C}_{3}$ photosynthetic pathway, thereby releasing them from control by fire (Midgley and Bond, 2015) and benefiting them at the expense of $\mathrm{C}_{4}$ species such as most southeastern grasses. The consequences of $\mathrm{CO}_{2}$ enrichment will likely depend on the level of moisture stressbeyond some threshold of moisture stress, $\mathrm{C}_{4}$ grasses may prosper even under much higher $\mathrm{CO}_{2}$ levels (Noss, 2018). What changes might be implemented for prescribed burning as a result? For example, burning during dry periods to control woody species.

- How does climate change affect the phenology of specific reproductive events for grassland plants, such as pollen-tube formation and germination? Some species require long cold periods to germinate and bear fruit. How will cold-season triggers be affected for events like budburst? Will cold-season signals needed for plant reproduction be interrupted by warmer winters or winter oscillations between warm and cold weather?

- Seed-germination studies usually are not specifically designed to answer climate-change questions such as those posed above. How could they be adjusted to best provide those kinds of information?
- Extreme heat has the potential to "cook the plant." In edaphic grasslands, some species have their life histories timed to avoid seasonal extremes in temperature and moisture. What are the ecological consequences if these extremes arrive at different times of the year than they did historically (for example, heat extremes in May rather than August)?

- Physiological tolerance thresholds during the initial period when a seedling is establishing and growing, for example, a seedling's first hot and dry summer, may be especially important (Bakker and others, 2003; Bernardo and others, 2016). How might the change of climate influence critical stages during the life cycle of a plant?

- How long do seeds remain viable in the soil? How resilient are seed banks to droughts and other extreme events? How does seed-bank viability and longevity vary among species based on environmental conditions? Similarly, how long are rootstock banks viable?

- There is a need for observational studies on potential for phenophase mismatch, for example, documenting the potential for the timing of budburst to shift out of sync with the timing of visitation by pollinators. Can records from iNaturalist and other similar databases be mined for this purpose? Herbarium records can be valuable for obtaining information on phenology (for example, Heberling and Isaac, 2017; SERNEC, 2020), as can iNaturalist (Heberling and Isaac, 2018).

- What are the most important physiological thresholds for grassland animals? How will those needs be affected by climate change? Physiological requirements are often not known for rare invertebrates, but temperature thresholds for completing different life cycle stages could be examined under controlled conditions.

- Grassland phenology is also important for migratory birds. Will the resources they require, such as insects and seeds, be available in the same grassland locations at the times when the birds need those resources? Which bird groups are most strongly affected by phenological changes, for example, changes in seasonal availability of their food resources?

\section{Impacts of Climate Change on Management Options and Constraints}

- How will climate change affect seasonal windows for prescribed fires? Do those effects vary by season (for example, burns in spring as conditions may be getting wetter, versus burns in fall)? What other factors shape prescribed-fire options, for example, changes in human population density, road networks, and the wildlandurban interface? 
- If managers are restricted in their use of fire to maintain grasslands, what other management techniques can be used to simulate fire effects, for example, combinations of mowing and targeted herbicides? These may be problematic, as research on fire surrogates generally find them useful for initial restoration treatments (that is, pretreatments for fire), but not as an effective replacement for fire in long-term management (Menges and Gordon, 2010; Noss, 2018).

- How will seasonal changes in soil moisture affect operating windows for microchipping and other forestry practices that are important for grasslands management and restoration (woody removal)? Companies that operate under sustainability requirements may be restricted from operating the necessary heavy equipment when soils are too wet because it can produce rutting and soil compaction. As a result, forestry operations (for example, in situ mastication) and harvesting may be affected by changing seasonality of soil moisture.

- What is the potential role for assisted colonization to conserve at-risk species? Assisted colonization approaches might be especially useful and (or) necessary for adaptation to sea-level rise. There is a need to differentiate short-distance assisted colonization (for example, to get across a narrow urban strip or highway) from longer-distance assisted colonization, as the risk of invasiveness might be higher if the recipient site is outside of the current range of the translocated species (Ricciardi and Simberloff, 2009).

- What is the role of ex situ conservation (for example, seed banks, conservation gardens) as a safety net for preventing extinctions? One workshop participant quoted the adage: "Better to be extinct in the wild than extinct, period." How do we know which sites and species should be foci for ex situ conservation as opposed to other conservation approaches? A recent review found that 66 percent of the extinct plants of the United States were single-site endemics, which suggests that efforts to identify and protect single-site endemics might help prevent extinctions and prioritize species for ex situ conservation.

- What should be the standards for site prioritization? If we can create classifications based on immediacy and urgency of need, we can then identify management options and strategies. High-priority sites (for example, with local endemics) under immediate threat of irreversible change such as inundation or development probably warrant the most intensive actions, such as ex situ conservation and (or) translocation. For some species, so few populations remain that it may be vital to create new populations in protected habitats to prevent their extinction.
- Should some grassland systems or sites be allowed to disappear? No other option may exist for those threatened by sea-level rise and other such immediate, irreversible, and presumably permanent threats. What methods should be used to identify the sites and ecosystems that fall into that category? Also, what time scales are most appropriate or relevant in deciding which systems "get triaged"? In the short term, areas that eventually will be lost may still hold great value. We need clear and scientifically supported protocols and guidelines to support these kinds of decisions and management actions.

- Many rare plant species in southeastern grasslands depend on specialized microhabitats (exposed outcrops, vernal pools, and so on). There is a need to assess how regional climate-change projections can be downscaled and otherwise modified to adequately capture the microclimate for these species and systems.

\section{Climate-Change Effects on Exotic and Invasive Species}

- As climate changes, will some invasive species be favored over native grassland species? Can we develop models to predict which invasive species will be the most successful competitors?

- Do we understand the sensitivity of invasive species to climate? In some cases, climate change may not be the most important factor driving invasions (Bradley, 2010). In other cases, where climate does strongly influence invasion, can we identify the climate thresholds or metrics that predict the spread of invasives? An attempt was made to do this for the imported fire ant (Solenopsis invicta); however, fire ants have already expanded out of the "possible" range predicted by this model and moved into the "improbable" range such as in several areas of Kentucky.

- Soil disturbance is often a major factor promoting invasions. How will climate change affect the balance between the need for management (sometimes requiring heavy equipment that disturbs soil) and potential for soil disturbance to facilitate spread of invasives (for example, cogongrass, Imperata cylindrica; Japanese stiltgrass, Microstegium vimineum; and the imported fire ant, Solenopsis invicta)?

- Agricultural pests and diseases can spill over into native plant communities. Some diseases may be favored under warmer temperatures. An example is a cotton virus attacking native mints near cotton fields. Thus, we need to identify these pests and diseases ahead of time and anticipate their potential responses to climate change. 


\section{Increasing Frequency of Extreme Events: Precipitation and Drought}

- What is the role of climate in shaping historical and current grassland distributions and geography?

- What are the climate factors that explain why a given grassland species assemblage occurs where it does (for example, interactions of climate with soils, geology, and disturbance)?

\section{Climate Effects on Distribution and Dispersal}

- To anticipate climate-change impacts to native grassland plants, there is a need to translate reduced precipitation (meteorological drought) into reductions in soil moisture (hydrologic drought), which varies by soil type. Can existing soil maps for the Southeast be used to classify soil types based on their sensitivity to drought?

- We know extreme drought can be catastrophic for some grassland plant and animal populations. Are there "tipping points" to drought beyond which populations cannot recover? If so, what are these?

- How do droughts affect soil-burrowing vertebrates (for example, moles, pocket gophers) and invertebrates (for example, ants, crayfish, earthworms) that are important for maintaining soil physical structure? Can a secondary effect of drought intensification be reduced soil turnover? With increasing drought, crayfish, and ants may burrow deeper and potentially go dormant and not fulfill their ecological role in turning over the soil. This could affect plant communities if root zone soil compaction increases.

- Birds in some types of grasslands (for example, hyperseasonal subtropical grasslands such as Florida dry prairie) often experience nest inundation during extreme rainfall events (Noss and others, 2008), and these events appear to be increasing. Can this be mitigated?

- Soil erosion increases with increasing hydraulic power of runoff from extreme rainfall events. Can soil erosion rates in grasslands be quantified and predicted?

- What are the interactions between increasing droughts and increasing extreme rainfall events?

- How do droughts affect trophic webs (for example, food resources for birds)? This is not well documented in the Southeast.

- How do changing hurricane patterns affect habitat conditions in coastal grasslands and even in some inland wetland systems? For example, clay-based Carolina bays typically dry out in most years. With increased hurricane activity, will this happen less often?

\section{Impacts of Climate Change on Disturbance Regimes}

- Climate change has been predicted to increase lightning activity by as much as 50 percent during this century (Romps and others, 2014). Are we seeing evidence of this increase? Will it also increase the incidence of dry lightning (lightning unaccompanied by significant rainfall)? Will increased lightning result in more wildfires, thus potentially favoring grassland over forest, or will any increase in fire be counteracted by increased fire suppression?

- Hydrological studies are needed to understand climate-change influences on streamflow, especially flood magnitude, frequency, and seasonality, and how this will impact riverscour grasslands. Hydrological modeling may be used to simulate flood events or interpolate from the existing streamgage network.

\section{Climate Change and Hydrologic Shifts in Wetland/Grassland Ecosystems}

- Baseline data are needed for reference-site hydroperiods to define restoration targets for wet grasslands.

- For groundwater-dependent grasslands, how will interactions between climate change, human groundwater use, and woody species patterns (that is, encroachment, afforestation, removal) affect groundwater discharge patterns and dynamics of soil moisture and inundation?

\section{Sea-Level Rise and Coastal Grasslands}

- Is there anything that can be done from an engineering perspective to buy time on sea-level rise for coastal grasslands? Coastal armoring through sea walls, abutments, dikes, and similar infrastructure is generally expected to do more harm than good because it will prevent adaptive coast-inland dispersal of species (Pilkey and Young, 2009), but other potential options should be explored.

- Land-use change projections are needed that incorporate projected human migration (coastal retreat) due to sea-level rise. Urban growth pressures are predicted to increase in inland areas of the Southeast as people flee the coasts (Noss, 2011).

- How will saltwater intrusion and changing soil salinity affect plant communities and burrowing invertebrates such as crayfish? 


\section{Miscellaneous/“Complete Unknowns"}

- How will climate change influence the soil microbiome, including the mycorrhizae essential to many vascular plants?

- We need better understanding of potential climatechange effects on soil formation processes and soil biogeochemistry. For example, nutrient leaching is primarily driven by precipitation and soil drainage effects, with implications for nutrients and soil fertility, which could then impact plant community composition.

\section{Changes to Disturbance Regimes}

As discussed earlier, many types of grasslands are disturbance dependent. Fire, flood, herbivory, windstorms, ice storms, and other mostly aboveground disturbances are essential to the maintenance of these grasslands, and grassland species have evolved mechanisms to avoid, tolerate, exploit, or promote disturbances, especially fire. Because species have adapted through natural selection to specific disturbance regimes (for example, Keeley and others, 2011), alteration of these regimes may produce conditions outside the evolutionary experience of native species, putting them at risk of extinction if they cannot adapt quickly enough. Other species, often nonnative, that are better adapted to the new disturbance regime may invade and come to dominate the community. Thus, changing disturbance regimes, often related to climate change (see above) or land-use change, constitute a major threat to southeastern grasslands. On the other hand, possible increases in fire activity with climate change may benefit firedependent species and communities unless natural wildfires continue to be effectively suppressed.

Below are some of the most critical research questions and science needs identified by the workgroups for southeastern grassland species and communities in relation to changing disturbance regimes:

\section{General Research Questions Related to Disturbance Regimes}

- A better understanding is needed regarding pre-European disturbance regimes for various grassland ecosystems and how disturbances and their combinations affected ecosystem structure, function, and composition. For example, the natural disturbance regime for mountain fens and associated rare species such as the federally threatened swamp pink (Helonias bullata) is not well understood, which complicates restoration and management.

- Research is needed regarding the implementation of managed disturbances under current and future conditions, given anthropogenic changes to the landscape.
- How can we better incorporate the landscape context (for example, the matrix surrounding remnant grasslands) for disturbance management? For example, smoke management is difficult for grassland patches within an urban matrix or adjacent to major highways.

- What is the range of variability in disturbance regimes that various grassland species experienced during their evolutionary histories? Presettlement conditions, in some cases going back millions of years, are informative of the range of variability that may be best tolerated by grassland species going forward. Exceeding that range of variability in any direction is expected to increase extinction risk.

Fire

- How much unburned habitat is required within a prescribed burn unit to provide adequate refugia for insects and other species vulnerable to fire? Greater biodiversity of plants with frequent fire may help support increased biodiversity of insect species.

- A quantitative model for fire-return intervals linked to changing climate is needed to better anticipate and mitigate potential impacts.

- It would be helpful to have projections for frequency of lightning strikes driven by climate models to anticipate how lightning frequency and seasonality may be changing for a given region and how those changes might translate to changes in ignition frequency.

- What communities and which species will be most vulnerable to changing fire regimes with climate change? It would be useful to develop a model of how fire behaves where those species occur and then link these models to climate-change projections.

- What are effective ways to overcome operational problems with fire management, especially to increase potential for prescribed burning on both public lands and private property?

- We need a better understanding of how burning affects insect populations of small patches.

- There is a need to identify where prescribed fire will be challenging or become untenable, such as the wildlandurban interface around expanding urban areas. This information can help managers assess the best alternatives for disturbance management, such as mechanical treatments, herbicides, grazing, and so on.

- The LANDFIRE dataset uses data on factors that influence fire regimes, including fuel type, woody debris, and so on. Through the LANDFIRE model, natural communities are monitored through time to show conditions suitable for fire. This framework 
could be strengthened by efforts to get the conservation community and private landowners to work together to submit data to LANDFIRE.

- Maps for fire regimes in the Southeast other than in the longleaf pine ecosystem are quite coarse. We need finer-scale resolution data from dendrochronology, historical land-survey information, and other approaches to infer fire regimes. Available data need to be collected and made available in a central repository.

- There is a need to develop a faster way to do preburn and postburn plot monitoring, such as through photo imaging of plots. In places with scarcity of data on fire effects, for example, how fire affects habitat structure, could there be standardized ways of using lidar (light detection and ranging) data to examine preburn and postburn habitat structure?

- More research is needed to determine the historical range of variability in fire intensity, seasonality, and return interval in various grassland communities across the Southeast. In particular, what are the thresholds regarding growing season (especially spring) burns and the decline of conservative grassland species outside of the longleaf pine ecosystems of the outer Coastal Plain?

- When does the growing season begin in various southeastern grasslands and what defines it? This information then needs to be placed into the framework of best times for prescribed burning and other management and how this window may need to shift with climate change.

- While progress has been made in applying more seasonally appropriate prescribed burns, a number of issues need to be addressed: (1) not taking into account condition of sites before applying growing-season burns, (2) concentrating growing-season burns during the March through May period when they would ideally be more variable into the summer or, depending on the region, even fall or winter months, (3) when a prescribed fire escapes, managers may be reluctant to burn in the future, and (4) for small-patch grassland communities, there is a tendency to burn these patches completely at a time of year (early spring) when invertebrates are most vulnerable, potentially leading to extirpations of bees, butterflies, grasshoppers, and so on.

- Plowed or disked fire breaks can degrade biodiversity in many ways (Noss, 2018), perhaps especially because they are often constructed along habitat edges or ecotones, where many rare species are concentrated. Best management practices for fire breaks need to be developed.

- What are best practices for retaining rare species in high-quality sites under fire management?

\section{Hydrology}

- How do wetland grasslands figure in estimates of both wetland loss and grassland loss?

- Better understanding is needed of riparian woodlands, floodplain meadows, and other grassy wet communities and how these systems grade into upland prairies/savannas.

- What role can grasslands play in wetland restoration and mitigation?

- How does management of the landscape matrix influence the hydrological condition of wet grasslands (for example, glade seeps)? For example, thinning of forests in the recharge areas of seepage slope communities can restore hydrology by reducing transpiration.

- To what extent are grassland systems maintained or shaped by hydrology? The impact of hydrology on many grassland systems is much more important than usually acknowledged. For example, how does the hydrological regime affect woody plant encroachment into grasslands, and vice versa? And how does climate change influence hydrology through changes in rainfall, wet and dry cycles, and other phenomena?

- What are the dynamics of open wetland types across the landscape, for instance, the frequency and duration of flooding? What constitutes extreme events? Many major rivers are now managed systems; thus, there is a need to understand how managers can maintain or simulate natural hydrological regimes in rivers affected by dams and other control structures.

- What is the impact of high flood events in the middle of the growing season? How will increased summer precipitation affect native grassland communities that evolved with flooding during the dormant season?

- What is the historical role of beaver in creating and maintaining grasslands such as floodplain meadows, bogs, fens, and canebrakes? What is the impact of beaver hydrological engineering and herbivory in a system where beaver movements are constrained by development?

- How will the indirect effects of climate change affect riverscour ecosystems, most of which occur along the banks of free-flowing rivers? For example, in the face of water scarcity, additional reservoirs may eventually be built in deep gorges, which have some of the best remaining riverscour habitat. Conversely, too much water may create a perceived need for flood-control projects.

- What are the effects of climate change and hydrological engineering on large river sandbar grasslands? Most of these have declined or been altered greatly due to flood control and navigation projects. 
- How do riverscour communities differ between dammed and undammed rivers? Specifically, how do high summer discharges from dams affect riverscour communities that historically flooded in the winter and spring and were generally not flooded in the summer? There is also a need for more research on the impacts of dams installed for flood control and of releases of water for whitewater recreation.

- Riverscour communities should be included in research being conducted on ecological flows in river systems (for example, Knight and others, 2012; Suen and Eheart, 2006).

\section{Herbivory}

- How does herbivory impact grasslands relative to grassland size? For example, in many small patch remnants, overabundance of white-tailed deer is problematic. Rodent herbivory is also negatively impacting some native grassland plant species.

- How can managers reintroduce stochasticity in grazing (mimicking more natural grazing regimes) as opposed to constant grazing pressure?

- How do grassland systems change with the removal of herbivory? Conversely, how has reintroduction or change of grazers affected grassland ecosystems?

- What are the effects of best management practices/ regenerative approaches for grazing in native grasses, including grazing regimes, cattle rotation, and so on? In what ways can cattle grazing mimic bison grazing, and in what ways does it not?

- What is the ecological role of grazing and benefits of grazing to grassland dependent wildlife such as birds, bog turtles, crayfish, insects, small wetland vascular plants, and to grassland soil microbes, soil health, water retention, and so on?

- There is a need to map grasslands that were thought to have been grazing dependent (for example, Bluegrass, Nashville Basin savannas, Ridge and Valley savannas) and perhaps less so fire dependent.

- Research is needed to determine the relative contribution of anthropogenic grazed grasslands to southeastern biodiversity of various groups, including which taxa are compatible and which are not.

\section{Educational Needs}

-What is the best way to educate landowners about the economic benefits of native perennials in a pasture?
- What is the most effective way for managers and researchers to reach out and educate homeowners, land-use planners, farmers, and businesses about the benefits of grasslands?

- What is the most effective way to educate staff of departments of transportation about the benefits of grassy roadsides?

\section{Remnants}

- Managers and researchers may need to develop a hierarchy of grassland management techniques under different conditions for different grassland types, which could be used by managers as well as landowners and the public.

- More information is needed about how to properly manage roadside grasslands and other remnants, in terms of timing of treatments, height of mowing, and optimal seasons and conditions for mowing (that is, wet or dry). Often on public lands mowing occurs before seed dispersal of some species because the timing of mowing is tied to getting lands ready for the hunting season.

- How can disturbance regimes (of many types) best be applied to small-scale native grassland remnants? An important caution is that large landscape processes don't necessarily apply to small remnants. For example, patch-burn grazing practices based on research from large grassland landscapes have been shown to sometimes negatively impact biodiversity when applied to small prairie remnants in western Missouri (Buckles and Harmon-Threatt, 2019; D. Kurz, unpub. data, 2010). Similarly, in Black Belt Prairie remnants, management techniques applied to large patches (burning, cut/lay/burn) were not effective; rather, the more labor intensive and costly method of cutting and hauling trees off site proved the best option for restoring the herbaceous flora (Hill and Barone, 2018).

- How can baseline conditions of a given remnant be considered when guiding management decisions? Do highly degraded sites differ from remnant sites in their response to fire-grazing management? Substituting cattle for bison does not always achieve conservation objectives (Kohl and others, 2013).

- Research is needed on how to best manage small sites, since there may be a tendency to manage the entire remnant as a single unit. The downside to this approach is that it may provide inadequate fire refugia for insects and other small animals.

- Almost all of the species on the SSA list in the Southeast exist in remnants. Hence, research is needed on remnant management since remnants are very important for rare species. 
- Almost all of the rare species are conservation reliant and management dependent. What management actions are required to keep populations viable, possibly in perpetuity?

\section{Mapping}

- For mapping historical distributions of grasslands, considerable information can be gleaned from historical data (land surveys, old plat maps, early civilian scientific expeditions, and so on), including landscape openness and tree species identity, and incorporated to increase robustness of the maps. Since tree species vary in their fire tolerance, recording tree identity is very important. Land descriptions in historical survey notes can be very helpful, for example, "first rate/second rate prairie" or areas of "poor timber."

- Indicator plant taxa and soil maps can be helpful in mapping historical grasslands.

- LANDFIRE biophysical settings used remnant grassland locations to "train" spatial models using climate, landform, and soil variables. Considerable "blind spots" in training data could be gleaned from historical records, such as land surveys, where historic grassland locations may be indicated with sufficient precision, as has been completed elsewhere (Albert and others, 2008).

- Lidar imagery of tar kilns in North Carolina's Coastal Plain and in the Cumberland Plateau of Tennessee revealed the historical importance of pine and fire in these systems. Similarly, west of the Mississippi River, lidar can be used to map nebkhas (also known as "pimple mounds," "prairie pimples," or "coppice dunes"), which are indicators of historical grasslands. Research is needed on how to incorporate lidar into management decisions.

- Could an assessment of historical river channel maps and riverbed sonar data be used to infer historical distribution of riverscour communities in impounded systems?

\section{Genetics}

- Gene flow is a crucial issue for conserving rare grassland species. Are there basic principles for mixing genotypes or best practices for artificial gene flow to promote future migration and adaptation? It would be helpful to categorize plants according to relative need for information on genetics and gene-flow dynamics.

\section{Invasive Species (Not Limited to Nonnative Species)}

Invasions by nonnative species and weedy native species constitute a fundamental threat to many natural communities, one that could potentially grow more severe with the stresses of climate change. Most regions absorb more species by invasion than they lose by extirpation, which suggests that communities are not saturated (all niche space occupied) except at very small scales (for example, $1 \mathrm{~m}^{2}$ in some grasslands) (Sax and others, 2007). This also suggests that invasions typically increase overall species richness, at least temporarily, which shows the folly of using raw species richness as a measure of conservation value (Fleishman and others, 2006). A paradox of invasion is that regions rich in native species are often also rich in exotic species - at least at broad spatial scales - but that loss of native species richness further accelerates invasions (Fridley and others, 2007). On the other hand, research at the community level shows support for biotic resistance, that is, nonnative plant occurrence is lower in communities with higher native plant species richness (Beaury and others, 2020).

Invasive nonnative species are thought to usually impact native species through intertrophic actions, that is, predation, parasitism, and disease, as opposed to competition with native species (Davis, 2003). However, competition between exotic and native plants has been documented, for example, the invasive cheatgrass (Bromus tectorum) in the western United States (and now established in the Southeast) often outcompetes native plants for soil resources (Leger and Goergen, 2017). In Kentucky, seedling establishment and vigor of the endangered local endemic Short's goldenrod (Solidago shortii) are reduced from competition with the nonnative crown-vetch (Securigera varia) and tall fescue (Lolium arundinaceum) (Walck and others, 1999). Other common impacts of invasive plants occur through alteration of natural disturbance regimes, especially fire, or through changes in nutrient levels, for example, with invasion by a nitrogen-fixing legume (Daehler, 1998).

A positive feedback relationship between flammable invasive grasses and fire often leads to dramatically increased fire frequency and intensity and produces an alternative vegetation state dominated by invasive grasses. Although this situation may be most common in arid ecosystems (for example, Klinger and Brooks, 2017), some invaders in the Southeast - for example, cogongrass - are highly flammable and are commonly observed to increase fire intensity and duration. Cogongrass and another exotic, Burma reed (Neyraudia reynaudiana), increase biomass of fine fuels and almost double the litter biomass (Platt and Gottschalk, 2001), thus intensifying fire beyond the natural range of variability and potentially leading to changes in community structure.

Conversely, plants with relatively nonflammable leaves, such as live oak (Quercus virginiana) and sand laurel oak (Q. hemisphaerica), can impede fire spread through a community or landscape (Kane and others, 2008). This is a common 
scenario in the Southeast, especially with woody invaders, whether native or nonnative. After a period of fire exclusion, native woody plants such as oaks and red cedars commonly invade grasslands and gradually reduce their ability to carry fire. As noted earlier, this can result in dramatic regime shifts from grassland to closed forest. In the absence of fire, red cedar (Juniperus virginiana) invades deeper soil areas of blackland prairies and limestone glades over a broad area of the Southeast. Once it grows beyond a certain size (about 1.5 meters [m] in height), it cannot be controlled by prescribed fire and can exclude fire from the community (Engle and Stritzke, 1995). However, red cedar mortality can depend on interactions between plant height, fire, and past grazing. Briggs and others (2005) discuss scenarios of greater than $(>)$ 80 percent mortality of red cedar trees up to $2.8 \mathrm{~m}$ tall in the presence of continuous grassland fuels.

Native oak species can also be invasive and alter fire regimes. Southeastern oak species vary substantially in their fire-adaptive traits and flammability (Hiers and others, 2014; Kane and others, 2008), such that some species facilitate fire spread while other species impede it. Sand live oak (Quercus geminata) is among several species of oaks with relatively nonflammable leaves (Hiers and others, 2014). After sand live oak invades a pine sandhill community and increases in height and basal area, its leaf litter builds up on the ground and grass cover declines dramatically. At some point fire is unable to pass through the stand or does so only very patchily. Eventually the community shifts to the alternative stable state of xeric hammock, a community that occurs naturally only on sites topographically protected from fire (Noss, 2018). Thus, land managers are urged to "prioritize removal of species that hinder prescribed-fire effectiveness" in southeastern grasslands (Kane and others, 2008).

In general, nonnative woody plant invaders have variable effects on fire regimes and can either increase or decrease fire frequency, intensity, and extent (Mandle and others, 2011). Oddly, fire effects of nonnative invasive species have not been studied thoroughly in the Southeast, though there are many anecdotal reports. Among the published studies, Stevens and Beckage (2009) found that the invasive Brazilian pepper (Schinus terebinthifolius), while fire sensitive, can reduce fire frequency and spread when it reaches high density during fire-free intervals.

Although most documented effects of invasive species are negative, in terms of impacts on natural ecosystems, agriculture, or human communities, it should not be assumed that all nonnative species have negative impacts. In a growing number of documented cases, nonnative species can assume the role of native species that have been extirpated. As one example, in New England salt marshes (a type of grassland), depletion of predators by overfishing allowed populations of the native herbivorous crab Sesarma reticulatum to explode and denude large areas of the native cordgrass Spartina alterniflora, causing salt marsh die-off. Invasion by the nonnative European green crab (Carcinus maenas), a predator, has greatly reduced Sesarma populations and allowed recovery of salt marsh vegetation in invaded areas (Bertness and Coverdale, 2013). In coastal prairies of Louisiana and Texas, the nonnative McCartney rose (Rosa bracteata) is highly invasive, but in over-grazed prairies it can serve the important role of sheltering native perennial grasses and forbs (including many conservative species) from grazing (Jason Singhurst, Texas Parks and Wildlife Nongame and Rare Species Program, oral commun., 2020). These and other examples suggest that managers may need to assess introduced species in terms of their ecological impact rather than on whether they are native (Davis and others, 2011).

Although native floristic quality is a legitimate management and restoration goal, often the percent cover of invasives is so high it is overwhelming to try to eradicate or suppress all of them. In these cases, the most prudent course would be to focus on those invasives (native or nonnative) with documented and strong negative impacts, such as for particular native grassland species of conservation concern. A complication is that unpredictable time lags may exist between the first appearance of an invader and its expansion in distribution and impacts on natural communities (Coutts and others, 2018). This problem underscores the value of early detection and, when deemed appropriate, control to prevent spread of nonnative invaders.

Even when the short-term impacts of a nonnative invader are clearly deleterious, evolutionary change in either the invader or the affected native species may alter relationships over time. Although the negative impacts of cheatgrass have been documented through numerous studies, its strong selective pressures on native perennial grasses have led some of them to evolve phenotypic traits that allow them to coexist with cheatgrass (Leger and Goergen, 2017). Cheatgrass has been best studied in the West, but it is increasingly invasive on glades in the Southeast, particularly west of the Mississippi River. Also, the high abundance of some invasive plants observed in the short term may be temporary. An illustrative example concerns Japanese stiltgrass (Microstegium vimineum), one of the most widespread invasive nonnative grasses in the eastern United States. Short-term studies generally show strong dominance of Microstegium over native herbaceous plants, but a longer-term study documented decline over time and replacement by native species. Both Microstegium and native herbaceous species responded positively to fire treatments in the short term, but after 8 years Microstegium was nearly absent and native herbaceous species had high biomass (Flory and others, 2017).

The workgroups identified the following concerns, questions, and research needs in relation to invasive species in southeastern grasslands:

\section{How Do We Define "Invasive"?}

- State and regional lists may include species that are limited in distribution and are low-priority threats to grassland communities, for example, wild carrot (Daucus carota). An effort is needed to rank invasives according to the scale and severity of the threats they pose to high-quality natural areas. 
- State and regional lists are not comprehensive, for example, honeybee could appropriately be considered invasive (or at least more widely recognized as nonnative). An effort is needed to improve these lists.

- Adventive species from other regions are a potential issue, for example, is there potential for Mexican hat (Ratibida columnifera), which is native to several southeastern grassland types west of the Mississippi River, to become invasive in grasslands outside its native range due to changing conditions and because it is commonly included in seed mixes? For example, this species is becoming prolific on roadsides in the Black Belt of Mississippi.

- Invasive genotypes may require special consideration. Invasive genotypes are often introduced in reclamation projects, for example, bushy bluestem (Andropogon glomeratus) in Pennsylvania, genetically altered loblolly pine (Pinus taeda) with faster growth and reproduction, and an aggressive switchgrass (Panicum virgatum) used in several areas for biomass production. Will these invasive genotypes dilute the native genotypes? What are their impacts on other native species? Managers need digestible resources to explain these concepts using nonspecialist language.

- How will the invasion effects of native/adventive species be altered in a changing climate and (or) with increasing anthropogenic influence? For example, anthracnose fungus is native but because of largescale horticultural production of Rosaceae, it now spreads more widely. The native versus nonnative status of Procambarus clarkii (Louisiana crayfish) is debatable in many areas, but it has expanded out of its native range. It is ecologically impactful and could spread into burrowing crayfish habitat (that is, bogs, seasonally wet prairies, and marshes).

\section{Horticulture}

- Invasive species problems are caused in part by the horticulture industry (Reichard and White, 2001). We need to explore partnerships and models, such as the one developed by the Ohio Invasive Plants Council (2020), to work with the horticulture industry in order to reduce the impact from invasive species on southeastern grasslands. Economic and cost-benefit analyses, and philosophical arguments such as the precautionary principle, may be needed to influence a paradigm shift in the horticultural industry.

\section{Mapping and Modeling}

- State invasive plant councils are involved in tracking and mapping of invasive species in a variety of ways. There is no active tracking activity in many States.
- A dedicated funding mechanism is needed for an early-detection alert system of invasions, which could be actively used by managers. Florida's Cooperative Invasive Species Management Area (CISMA) network could be a good model for this (Amy Jenkins, Florida Natural Areas Inventory, written commun., 2020). It is also critical that an early-detection system be coupled with a more organized rapid response system to control invasive species.

- An important need is matching grassland communities with invasive threats. What invasives are likely to be found in specific communities in specific regions? Citizen scientists could be organized to map invasive species occurrences, perhaps on iNaturalist, which can then be correlated with ecological systems or other community types. This information could inform the NatureServe I-rank concept (like S and G ranks).

- Modeling is needed to determine the vulnerability of grassland communities to invasive species in the context of changing climate. For example, if xeric habitats become wetter, could this increase Microstegium invasion in shale barrens? Could wetter conditions have other effects, such as the spread of chytrid fungus in certain habitats?

\section{Resiliency of Ancient, Old-Growth, Remnant Grasslands}

- We need better definitions and reference concepts for old-growth southeastern grasslands similar to reports that provide such definitions for forest types. On a global scale, Bond (2016) notes "striking differences in old-growth versus secondary grasslands," and that "ultimately, old-growth versus secondary grasslands will have to be classified by identifying characteristics of the herbaceous layer, such as grass composition, that are visible from satellites and that are also proxies for primary grasslands."

- It is clear that invasive species usually do not establish as effectively in intact grasslands (or other kinds of intact ecosystems, such as old-growth forests) as in disturbed or degraded ones. Research is needed to determine what factor(s) are important in determining intact versus degraded grasslands and their susceptibility to invasion.

- Information gaps include the following: Is resiliency a function of historical disturbance? Will that resiliency change in the face of a changing climate? How can management be used to improve resiliency? For example, on Florida's Big Pine Key, rare endemic plants in sample plots that had burned more frequently were more resilient to hurricane impacts (Keith Bradley, South Carolina Department of Natural 
Resources, written commun., 2020). What are the direct and indirect mechanisms that cause rare species to decline due to invasion (outshading and so forth)? What are the lasting impacts of invasive species after they are successfully removed, for example, related to soil chemistry or soil biota? More research and review of existing research is needed on these topics.

- A better understanding is needed of the complexities of grassland ecosystems in relation to understudied factors that might play a role in influencing native communities and invasive species, for example, soil and mycorrhizal associations.

- Research is needed on how coefficient of conservatism and Floristic Quality Index can be used to identify intact systems (for example, Reemts and Eidson, 2019).

- More research is needed on the soil seed banks of invasive species and the challenges they represent for restoring or re-creating grasslands.

\section{Herbicides and Fungicides}

- We commonly lack toxicity tests for rare plants and animals related to application of herbicides and fungicides.

- How does chemical treatment affect rare plants? More research is needed on these effects, for example, a small-scale experiment on Price's potato-bean (Apios priceana) and spot treatment of Chinese bushclover (Lespedeza cuneata) where it co-occurs with leafy prairie clover (Dalea foliosa).

- There is a paucity of experts in fungal pathogens such as rusts and smuts. In the absence of taxonomy, there is a need for a DNA barcode database for rusts and smuts that can be used in early detection. There may be potential for grassland managers to partner with plant pathology departments at universities.

\section{Diverse Partnerships Are Crucial}

- There is a need to address the issue that many remnant grasslands are small areas that are not systematically managed or monitored or are at risk of not being systematically managed and monitored.

- Grassland conservation would benefit from a mechanism to bring public and private stakeholders together under the grassland conservation umbrella. For example, Tennessee Valley Authority rights-ofway cross Tennessee Wildlife Resources Agency Wildlife Management Areas with adjacent private landowners. What mechanism might facilitate the collaboration of these stakeholders under the grassland conservation umbrella?

- There needs to be more communication and cooperation between diverse partners, for example, Natural Resources Conservation Service-like programs and U.S. Forest Service or other agency assistance with private controlled burns. Even after partnerships are established, there will be a continuing need to educate agency staff, for example, field technicians.

\section{Invasive Species Issues Are Often Site-Specific and May Not Be the Primary Management Concern}

- Invasive species might be a lower threat than other issues in some areas, for instance, curbing encroachment by woody native species might be a higher priority than eradicating herbaceous invasives such as wild carrot (Daucus carota).

\section{Preventing Invasive Spread}

- There is a need to reconcile invasives management with other management activities. For example, whereas many invasions are associated with anthropogenic soil disturbance, disturbance-related conservation and management activities such as construction of trails or fire lanes are necessary. How can these be reconciled?

- What happens when the established native flora is killed with herbicide (when spraying invasives), which then suddenly opens niche space for invasive plants in the form of bare soil?

- Cleaning equipment, including vehicles and boots, can help reduce spread of invasives. Best management practices are needed to assure appropriate protocol is followed by staff and contractors. Improved education (perhaps an expansion of existing public education programs on invasives such as PlayCleanGo) may encourage more compliance. Educational materials also need to include information on invasive insects that may hitchhike on equipment, such as Argentine ants (Linepithema humile) and tawny crazy ants (Nylanderia fulva).

- What influences susceptibility of a community to invasion? Does increased nitrogen from fertilizer or cattle adjacent to grassland remnants and natural areas increase invasion potential? Are limestone soils usually more susceptible to invasion? Anecdotally, areas that are acidic or high elevation tend to be more resilient, but this may depend on the region. 


\section{Fire and Invasives}

- Research is needed on the effects of prescribed-fire seasonality, intensity, and return interval on invasion and on invasive-species control in various grassland communities.

- Context is critical. There needs to be research conducted on how fire regimes and susceptibilities to invasion after burning differ among grasslands.

\section{Specific Cases of Invasives}

- Threats from crop viruses, for example, cotton viruses overwintering in native plants, need to be assessed.

- Crop rusts pose a unique threat. For example, the rare American barberry (Berberis canadensis), which occurs in a number of southeastern grasslands (glades, barrens, and rocky savannas and woodlands) is an alternate host for a wheat rust, which led to a federal campaign to eradicate the barberry. What conservation measures can be used to recover populations of this species in grasslands?

- Use of biological controls on invasives in grasslands needs to be assessed, especially whether they can become invasive themselves or otherwise adversely impact these systems.

- Afforestation, even with native tree species, in naturally treeless or sparsely treed grasslands needs assessment since it is a grave threat in some areas (Veldman and others, 2015). In some cases, for example, melaleuca (Melaleuca quinquenervia) in Florida, planted nonnative trees invade a broad region.

- Feral hogs have impacts on many grassland types. Their rooting can cause major soil disturbance, alter ecosystem structure, eliminate rare plant populations, and create opportunities for other invasive species. Current efforts to control hog populations by trapping and hunting are generally not effective as implemented. Better control methods are needed.

\section{Localized or Subregional Impacts}

Finally, the workgroups considered issues of information needs associated with localized or subregional impacts such as sea-level rise, as well as general information needs that did not easily fit within the categories discussed above. The following points and questions emerged from the discussions:

\section{Inventory}

- There is a need for expanded training in taxonomy of plants and of invertebrate taxa, especially poorly known ones. Some signs of optimism include the National Science Foundation's Poorly Sampled and Unknown Taxa (PurSUiT) programs and continuing work by research museums.

- There is a need for cross-disciplinary work, for example, plant ecologists collaborating with zoologists and animal ecologists to address plant-animal interactions.

- Increased support is needed for baseline and inventory data collection, especially in high-elevation grassland communities and coastal grasslands, which are particularly at risk from climate change because they often have nowhere to move. The Coastal Prairie Partnership, whose mission is to promote and support the conservation and restoration of coastal prairie ecosystems in Louisiana and Texas, is trying to address these issues.

- Specialists need to share search images with citizen scientists to help facilitate discovery of additional remnants of heavily fragmented (or otherwise isolated small-patch) grassland communities. Such search images are needed for both ground searches and remote sensing. Examples of ecosystems in which this would be particularly helpful include Black Belt and other blackland prairies.

- Comparisons between winter and summer remote-sensing data (specifically color-infrared imagery) can be used to distinguish cool versus warm season grasses. Researchers might look to the National Aeronautics and Space Administration for information and guidance on new remote sensors (including lidar and hyperspectral imagery) to help identify particular plant species and communities. Researchers need to identify good places to test mapping and conservation concepts.

- For many grassland remnants, the invertebrate fauna is poorly understood. More studies are needed to identify which species are found where, as well as what their needs are related to plant resources, refugia, and so on.

- Many State Natural Heritage Programs are far behind in entering information on priority grassland (and other habitat) sites into their databases, which presents a major capacity issue for habitat management. There is a need to support staffing in these programs to support this data entry.

\section{Mapping}

- More research is needed to determine the existing footprint for relatively high-elevation grassland communities within the Appalachians (both Blue Ridge and Cumberland Plateau) and Ozark-Ouachita Highlands. 
- Mapping of grassland types needs to be standardized. Researchers and managers need to ensure that classification types are current across all States, ensure definitions are consistent where appropriate, and identify where to develop new types. VegBank (2020) could be a possible central repository.

- For the West Gulf Coastal Plain, there is a need to map chalk (limestone) glades.

\section{Modelling}

- Further research is needed to project human migrations inland from coastal areas due to sea-level rise and continued movements from elsewhere into the Southeast during the next several decades, matching development pressures with existing grassland focal areas (for example, especially the Nashville Basin, Arkansas, Piedmont, and Florida).

- There is a need to project how much flexibility may remain for high-elevation grassland communities persisting into the future. This may require distinguishing projections for south and west (typically drier) slopes from north and east (typically moister) slopes. For the latter, high elevation cliff-face communities may respond differently due to variable projections involving precipitation.

- There is a need to project changes in streamflow related to rainfall in terms of seasonality and duration and potential effects on riverscour grasslands. There is concern about more short-term intense flooding during more sensitive times of year for flowering plants (which may also affect insects such as dragonflies, tiger beetles, and so on).

- There is a need to project levels of flexibility in available prescribed burn days in the future especially with respect to changing daily temperatures and humidity.

- There is a management need to identify and prioritize lands for conservation (some States are further along than others), grassland or otherwise. Some places are growing in human population faster than others, with some areas under extreme threat, especially areas of high species endemism. Research and management would benefit from standardized rankings for sites across State programs, as well as efforts to document capacity for conservation action and how it varies across regions, incorporating climate-change factors as needed.

- There is a need to connect the Southeastern Climate Adaptation Strategy (SECAS) with SGI and its partners (SECAS, 2020; Southeastern Grasslands Initiative, 2020). SECAS is a regional conservation initiative that spans the southeastern United States and the U.S. Caribbean (fig. 7) formed by the Southeastern Association of Wildlife Agencies and the Federal agencies of the Southeastern Natural Resource Leaders Group (SECAS, 2020). SECAS works to design and achieve a connected network of lands and waters to benefit ecosystems, species, and people. SECAS tracks regional metrics of ecosystem health, function, and connectivity to report annually on progress toward achieving the SECAS 10 percent goal. SECAS developed and maintains the Southeast Conservation Blueprint, a living, spatial plan that identifies the most important areas for conservation and restoration across the region (fig. 8). It stitches together smaller subregional plans into one unifying map - a spatial action plan for achieving the SECAS vision and goal. It is an iterative product that is updated based upon an ongoing process of feedback and revision by SECAS partners and Blueprint users. More than 225 people from over 100 organizations have used or are using the Blueprint in their work. SECAS can provide modeling and toolkit products to SGI and State natural heritage programs, most notably the SECAS Blueprint.

- There is a need to incorporate plants into State Wildlife Action Plans where not already done.

- Researchers can develop habitat suitability modeling for at-risk species and prioritization of sites for habitat and population conservation. These efforts could take advantage of the recently released NatureServe Map of Biodiversity Importance (for example, fig. 1).

\section{Management, Conservation Actions, and Concerns}

- To conserve riverscour barrens, there is a need to address the impacts of dams and water releases resulting in long-term inundations during inappropriate times of year (from the perspective of riverscourdependent native plant species)—for example, during popular times for rafting and kayaking. A specific example is for the Hiawassee and Ocoee Rivers impacting Ruth's golden-aster (Pityopsis ruthii) and an undescribed Solidago species.

- There is a management need to address "rock picking" (removal of ledge rock for the landscaping industry) in the Ozarks-Ouachita Highlands impacting glades and sites occupied by State-rare eastern collared lizards (Crotaphytus collaris). There may be a similar issue for Interior Low Plateau glades and barrens. Similarly, cobble removal in streams impacting riverscour habitats is an increasing problem, as is removal of rocks from streams inhabited by hellbenders (Cryptobranchus alleganiensis).

- There is a management need to address feral hog invasions that are impacting glade communities, bogs, savannas, and other grasslands and changing disturbance regimes. 


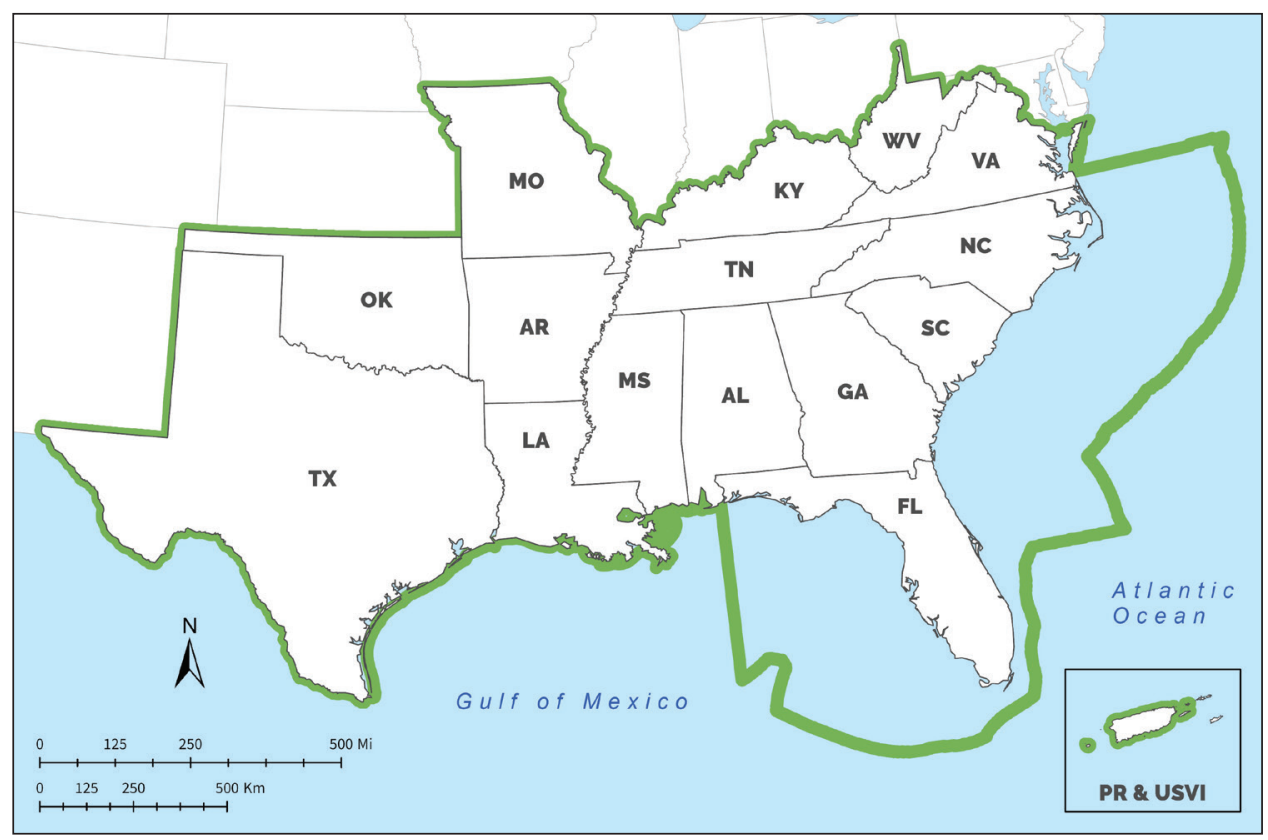

Figure 7. The Southeast Conservation Adaptation Strategy (SECAS) geography. SECAS brings together State and Federal agencies, nonprofit organizations, private businesses, Tribes, partnerships, and universities around a shared vision of the future.

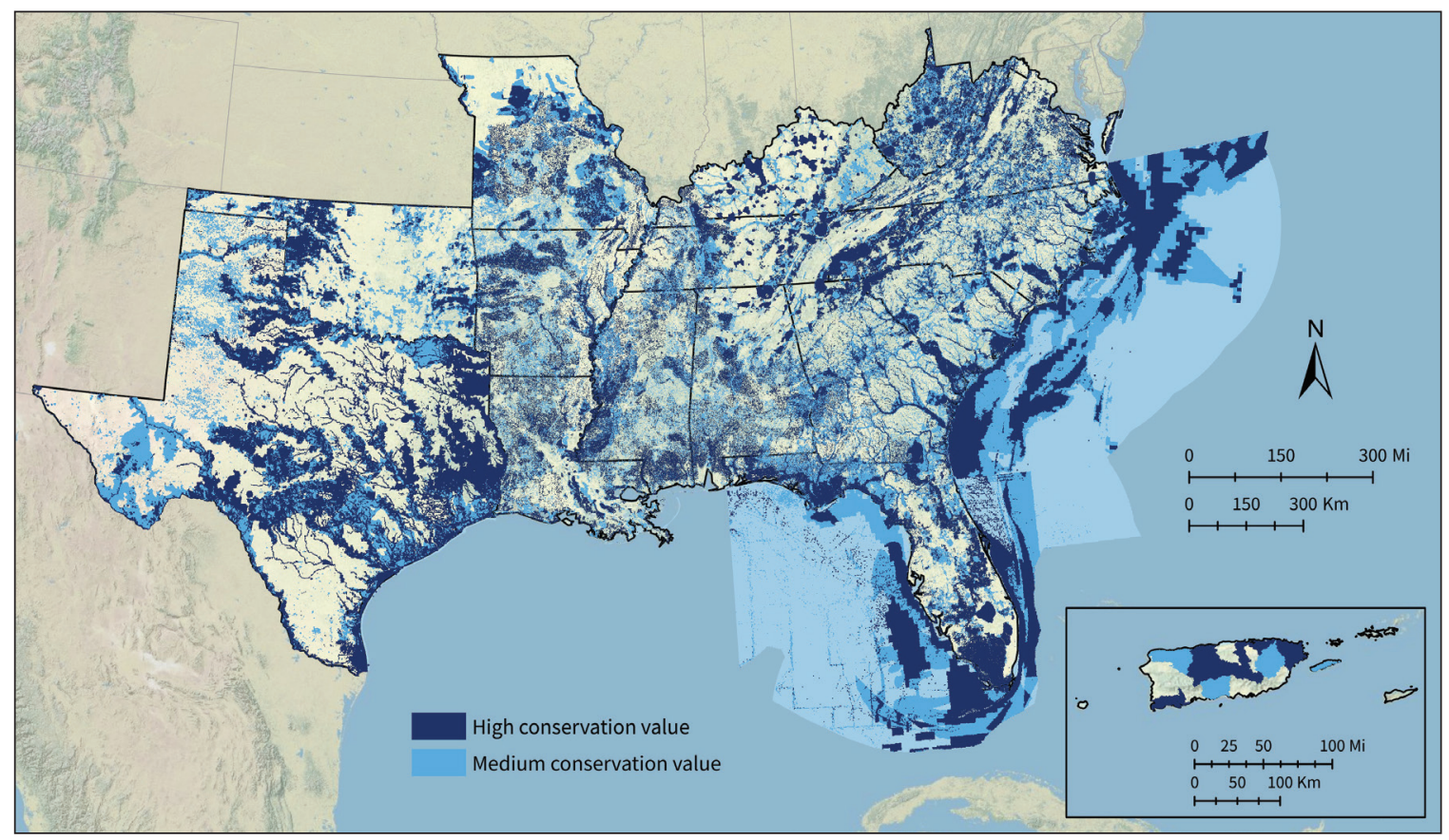

Figure 8. The Southeast Conservation Blueprint. High conservation value: These areas are the most important for ecosystem health, function, and connectivity. Medium conservation value: This category captures areas that might require more restoration but are important for buffering high value areas and maintaining connectivity (http://secassoutheast.org/blueprint). 
- There is a need to address the lack of disturbance maintaining sandy openings, which are important for grassland taxa restricted to xeric (that is, Lake Wales Ridge) and coastal scrub, as well as sandhill communities across the Southeast. This is important for many grasshopper and beetle species, for example, the Highlands tiger beetle (Cicindela highlandensis), which is endemic to central Florida.

- There is a need to address increasing incompatibility of herbicide use along rights-of-way (utility, roadsides, and so on) now supporting many at-risk and listed species where natural habitat outside of rights-of-way is presently lacking.

- Regarding small, isolated remnant grasslands surrounded by agricultural fields, there is a need to address lack of field edges around crops and pesticide drift. There may be opportunities to tie such efforts in with the National Bobwhite Conservation Initiative as well as Natural Resources Conservation Service programs.

- For land-protection strategies, there is a need to develop an online marketplace for conservationoriented land sales, to help match priority opportunities for protection (for example, sites with high threats and high endemism) with organizations that can broker transactions. Ideally, the first step of being alerted when a high-value site is up for sale would be automated and conservation partners in the region would be automatically notified when a site becomes available. Such an effort could seek out the Land Trust Alliance as a possibility for helping facilitate this online marketplace. There may be opportunities to explore certification programs for forest landowners because forest-oriented lands often also have grassy habitats.

\section{Monitoring}

- Monitoring is generally poorly supported by agencies. There is a need for standards.

- A lack of skilled field scientists, particularly botanists and entomologists, affects the ability of many agencies to conduct adequate monitoring. This issue of capacity needs to be addressed.

- An example of a worthwhile monitoring program is the monitoring of effects of grazing and burning in Louisiana (Calcasieu Parish, coastal prairie; cattle ranches on unplowed ground).

\section{Research}

- For Nashville Basin limestone (cedar) glades, there is a need for study related to historical woody encroachment in relation to fire. Well-maintained glades have shallow soil. How could these habitats best be man- aged with prescribed fire? Many sites said to be former glades are now dominated by red cedar, perhaps due to encroachment from glade edges with soil accumulated after decades of fire suppression. What role did bison play in maintaining open glades? In general, there is a need for additional archaeological/paleontological research to understand megafauna during the Holocene and earlier.

- For the West Gulf Coastal Plain, managers need to better understand cedar invasion and the potential roles played by fire and mechanical control.

- There is a need to define the roles that herbivores (or possibly fire) played for maintaining balds and bogs in the Appalachians. The climate-herbivore hypothesis (Weigl and Knowles, 2014) is currently the bestaccepted hypothesis for the origin and maintenance of Southern Appalachian grassy balds. Can this be tested by paleoecological research?

- There is a need to define which grasslands in the Southeast were grazing dependent or created (for example, Bluegrass).

- For a number of at-risk taxa that are widely scattered across the Southeast, there is a need to form communication networks as a way of working across geographies to promote conservation by better understanding what the sites supporting these species may have in common. Examples include small-headed pipewort (Eriocaulon koernickeanum), known from the Interior Highlands of Arkansas and Oklahoma, with outlier populations on the adjacent coastal plains of Oklahoma and Texas, and in the Piedmont of Georgia.

- There is a need to investigate the role of climatic refugia and the hypothesis that some grassland types within the northern portion of the Southeast may have persisted through glacial periods (for example, Braun's research on southern Ohio hillside prairies; Braun, 1951). In some cases, edaphic grasslands might serve as microrefugia (see earlier discussion in the subsection "Climate Change").

- Better understanding is needed of the connectivity between certain glade types, their role as ephemeral wetlands, and their connectivity to groundwater or surface streams.

\section{Education}

- There is a need to develop outreach materials to educate fire staff, ecologists, landowners, sportsmen, and the general public about prescribed burning, but with consideration of the need to fine tune the application with both plants and invertebrates in mind. Regional prescribed-fire councils or prescribed-burning associations may be partners in such an effort. 
- For glades (for example, in the Nashville Basin of Tennessee and in the Ozarks), there is a need to keep in mind the karst and cave aquifers that underlie many of these grassland communities. Conservation of these surface habitats can help secure clean water.

\section{Next Steps and Remaining Research Questions and Science Needs}

The workshop described above and this resulting report offer preliminary identification of science and information needs and guidance for conservation planning for grassland species and communities of conservation concern in the Southeast. Several overarching research and management needs stand out for guiding future progress in conserving native southeastern grasslands:

- Rather than pursuing a species-by-species approach to the SSA process, it would be helpful to group species by habitat or functional groups (for example, abiotic habitat associations, ecological systems, National Vegetation Classification macrogroups, life histories, or guilds). Then, functional groups and their species can be associated with specific ecosystems or conditions in which they occur. This is the basis for coarse-filter conservation. For attributing at-risk species to habitats or communities, a hierarchical framework is preferred, for example, from ecological systems to National Vegetation Classification groups, then macrogroups.

- Even when applying an ecosystem-based approach to the SSA process, prioritization is needed to manage the workload and, most importantly, to be sure species do not decline toward extinction during the SSA process. Thus, the highest priority SSAs would generally be for species associated with IUCN critically endangered ecological systems ( $>90$ percent decline), followed by those associated with endangered $(>70$ percent decline), and vulnerable ( $>50$ percent decline) ecological systems.

- Toward this end, an immediate need is to refine maps of historic and current distribution of grassland ecosystems in the Southeast (see Comer and others, 2018, for a commendable approach) - and the biophysical settings with which they are associated - and to calculate the extent of decline of each ecological system. Research on this topic by NatureServe is ongoing and draft maps have been produced, so the USFWS could defer to NatureServe's analyses. Mapping would ideally proceed at multiple spatial scales and resolutions. A good example of historic vegetation mapping is the effort by the Florida Natural Areas Inventory, which has developed historic natural community maps for more than 1 million ha (2.5 million acres), including
320,000 ha $(800,000$ acres $)$ in the Apalachicola region at a scale as fine as $0.2 \mathrm{ha}$, albeit only for public lands so far (Amy Jenkins, Florida Natural Areas Inventory, written commun., 2020).

- Methods for identifying and prioritizing sites for grassland conservation and restoration must be further developed and rigorously applied across the Southeast.

The workshop participants repeatedly noted the caveat that generalizations about how to apply the SSA process for southeastern grassland species can only be taken so far. The broad study region defined as the Southeast in this project encompasses tremendous variation in landform, geology, soils, hydrology, vegetation, flora, and fauna. For all research questions and applications, it is critically important to recognize the heterogeneity of the region. Southeastern grasslands encompass more than one hundred ecological systems (appendix 1) ranging from 24 degrees to 42 degrees latitude, from 71 degrees to 99 degrees longitude, and from sea level to $>2,011 \mathrm{~m}(6,600 \mathrm{feet})$ in elevation. They range across dozens of geological substrates and soil types and a wide range of moisture conditions. Some southeastern grassland communities are natural matrix communities, the dominant type within their ecoregion. Others are large patch, small patch, or linear communities. This landscape context may help influence their sensitivity to climate change, habitat fragmentation, and other threats and their requirements for management. For example, with adequate buffering and management, many small-patch communities can be effectively conserved within small reserves, whereas matrix and large-patch communities probably require very large managed areas to function naturally and maintain all their species and characteristic processes. A conservation solution for one type of ecological system or even a local representative of that type cannot be applied uncritically to other types or representatives. Still, a synthesis of feedback from workshop participants emphasizes some principles, empirical generalizations, and research needs as applicable to conservation and management across grassland types:

- There is a fundamental need to identify and map potential climatic microrefugia for grassland species throughout the Southeast. Possible locations of microrefugia can potentially be identified through fine-scale topoclimatic modeling and geological data and inferences from paleoecology and phylogenetics. Even if these putative microrefugia turn out to be temporary hospices for species at risk, given the rate and severity of climate change, this short-term persistence may buy time for other conservation actions, such as ex situ conservation (Morelli and others, 2020).

- There is a need for a decision-support system for ecosystem-based SSAs. The USFWS will be much better equipped to improve and streamline the SSA process if explicit stepwise guidance is available. 
- Methodologies for assessing the condition, quality, and integrity of local examples (sites) of ecological systems need refinement.

- The loss of distinct evolutionary lineages of organisms is a strong possibility when ecosystems become as endangered as southeastern grasslands. Studies of phylogenetic community structure are needed.

- There is a need to determine which species will still require individual attention to achieve recovery under a coarse-filter approach to SSAs and to conserve and restore grassland ecological systems in general.

- Collaborative research projects targeted at addressing the most pressing scientific needs for conserving southeastern grassland species of conservation concern are greatly needed.

Finally, a critical need is to increase public awareness and understanding of southeastern grasslands, their extent of decline and current threats, and their requirements for conservation and restoration. Without an informed and engaged public, long-term conservation is probably impossible.

\section{References Cited}

Abatzoglou, J.T., and Williams, A.P., 2016, Impact of anthropogenic climate change on wildfire across western US forests: Proceedings of the National Academy of Sciences of the United States of America, v. 113, no. 42, p. 11770-11775.

Adams, H.D., Barron-Gafford, G.A., Minor, R.L., Gardea, A.A., Bentley, L.P., Law, D.J., Breshears, D.D., McDowell, N.G., and Huxman, T.E., 2017, Temperature response surfaces for mortality risk of tree species with future drought: Environmental Research Letters, v. 12, no. 11.

Albert, D., Comer, P., and Enander, H., 2008, Atlas of early Michigan's forests, grasslands, and wetlands: East Lansing, Michigan, Michigan State University Press, 136 p.

Auffret, A.G., Rico, Y., Bullock, J.M., Hooftman, D.A.P., Pakeman, R.J., Soons, M.B., Suárez-Esteban, A., Traveset, A., Wagner, H.H., and Cousins, S.A.O., 2017, Plant functional connectivity-Integrating landscape structure and effective dispersal: Journal of Ecology, v. 105, no. 6, p. $1648-1656$.

Bakker, J.D., Wilson, S.D., Christian, J.M., Li, X., Ambrose, L.G., and Waddington, J., 2003, Contingency of grassland restoration on year, site, and competition from introduced grasses: Ecological Applications, v. 13, no. 1, p. 137-153.

Baskin, J., and Baskin, C., 1988, Endemism in rock outcrop plant communities of unglaciated eastern United StatesAn evaluation of the roles of the edaphic, genetic and light factors: Journal of Biogeography, v. 15, no. 5, p. 829-840.
Baskin, J., Chester, E., and Baskin, C., 1997, Special paperForest vegetation of the Kentucky karst plain (Kentucky and Tennessee) - Review and synthesis: Journal of the Torrey Botanical Society, v. 124, no. 4, p. 322-335.

Bátori, Z., Vojtkó, A., Farkas, T., Szabó, A., Havadtoi, K., Vojtkó, A.E., Tölgyesi, C., Cseh, V., Erdos, L., Maák, I.E., and Keppel, G., 2017, Large- and small-scale environmental factors drive distributions of cool-adapted plants in karstic microrefugia: Annals of Botany, v. 119, no. 2, p. 301-309.

Beaury, E.M., Finn, J.T., Corbin, J.D., Barr, V., and Bradley, B.A., 2020, Biotic resistance to invasion is ubiquitous across ecosystems of the United States: Ecology Letters, v. 23 , no. 3 , p. $476-482$.

Beerling, D., 2007, The emerald planet-How plants changed Earth's history: New York, Oxford University Press.

Beier, P., and Noss, R.F., 1998, Do habitat corridors provide connectivity?: Conservation Biology, v. 12 , no. 6 , p. 1241-1252.

Bell, D.M., Bradford, J.B., and Lauenroth, W.K., 2014, Mountain landscapes offer few opportunities for high-elevation tree species migration: Global Change Biology, v. 20, no. 5, p. 1441-1451.

Belue, T.F., 1996, The long hunt—Death of the buffalo east of the Mississippi: Mechanicsburg, Pa., Stackpole Books, 260 p.

Bernardo, H.L., Albrecht, M.A., and Knight, T.M., 2016, Increased drought frequency alters the optimal management strategy of an endangered plant: Biological Conservation, v. 203, p. 243-251.

Bertness, M.D., and Coverdale, T.C., 2013, An invasive species facilitates the recovery of salt marsh ecosystems on Cape Cod: Ecology, v. 94, no. 9, p. 1937-1943.

Bonan, G.B., 2008, Forests and climate change-Forcings, feedbacks, and the climate benefits of forests: Science, v. 320 , no. 5882 , p. $1444-1449$.

Bond, W.J., 2016, Ancient grasslands at risk: Science, v. 351, no. 6269 , p. $120-122$.

Bond, W.J., Woodward, F.I., and Midgley, G.F., 2005, The global distribution of ecosystems in a world without fire: New Phytologist, v. 165, no. 2, p. 525-538.

Bradley, B.A., 2010, Assessing ecosystem threats from global and regional change-Hierarchical modeling of risk to sagebrush ecosystems from climate change, land use and invasive species in Nevada, USA: Ecography, v. 33, no. 1, p. 198-208.

Braun, E., 1928, Glacial and post-glacial plant migrations indicated by relic colonies of southern Ohio: Ecology, v. 9, no. 3, p. 284-302. 
Braun, E., 1955, The phytogeography of unglaciated eastern United States and its interpretation: Botanical Review, v. 21, no. 6 , p. 297-375.

Braun, E.L., 1951, Plant distribution in relation to the glacial boundary: Ohio Journal of Science, v. 51, no. 3, p. 139-146.

Briggs, J.M., Knapp, A.K., Blair, J.M., Heisler, J.L., Hoch, G.A., Lett, M.S., and McCarron, J.K., 2005, An ecosystem in transition-Causes and consequences of the conversion of mesic grassland to shrubland: Bioscience, v. 55, no. 3, p. 243-254.

Brown, S.C., Wigley, T.M.L., Otto-Bliesner, B.L., Rahbek, C., and Fordham, D.A., 2020, Persistent Quaternary climate refugia are hospices for biodiversity in the Anthropocene: Nature Climate Change, v. 10, no. 3, p. 244-248.

Brudvig, L.A., Orrock, J.L., Damschen, E.I., Collins, C.D., Hahn, P.G., Mattingly, W.B., Veldman, J.W., and Walker, J.L., 2014, Land-use history and contemporary management inform an ecological reference model for longleaf pine woodland understory plant communities: PLoS One, v. 9, no. 1, p. e86604, accessed February 13, 2021, at https://doi.org/10.1371/journal.pone.0086604.

Buckles, B.J., and Harmon-Threatt, A.N., 2019, Bee diversity in tallgrass prairies affected by management and its effects on above- and below-ground resources: Journal of Applied Ecology, v. 56, no. 11, p. 2443-2453.

Cartwright, J., 2019, Ecological islands-Conserving biodiversity hotspots in a changing climate: Frontiers in Ecology and the Environment, v. 17, no. 6, p. 331-340.

Cartwright, J., and Wolfe, W.J., 2016, Insular ecosystems of the southeastern United States-A regional synthesis to support biodiversity conservation in a changing climate: U.S. Geological Survey Professional Paper 1828, 162 p. [Also available at https://doi.org/10.3133/pp1828.]

Comer, P.J., Hak, J.C., Kindscher, K., Muldavin, E., and Singhurst, J., 2018, Continent-scale landscape conservation design for temperate grasslands of the Great Plains and Chihuahuan Desert: Natural Areas Journal, v. 38, no. 2, p. 196-211.

Costanza, J.K., Terando, A.J., McKerrow, A.J., and Collazo, J.A., 2015, Modeling climate change, urbanization, and fire effects on Pinus palustris ecosystems of the southeastern U.S: Journal of Environmental Management, v. 151, p. 186-199.

Coupland, R.T., ed., 1991, Natural grasslands-Introduction and Western Hemisphere, v. 8A of Ecosystems of the World: Amsterdam, Elsevier, 469 p.

Coutts, S.R., Helmstedt, K.J., and Bennett, J.R., 2018, Invasion lags-The stories we tell ourselves and our inability to infer process from pattern: Diversity \& Distributions, v. 24, no. 2, p. 244-251.
Cretini, K.F., Visser, J.M., Krauss, K.W., and Steyer, G.D., 2012, Development and use of a floristic quality index for coastal Louisiana marshes: Environmental Monitoring and Assessment, v. 184, no. 4, p. 2389-2403.

Critical Ecosystem Partnership Fund, 2016, North American Coastal Plain: Critical Ecosystem Partnership Fund web page, accessed August 28, 2020, at https://www.cepf.net/ our-work/biodiversity-hotspots/north-american-coastal-plain.

Critical Ecosystem Partnership Fund, 2020, Biodiversity hotspots defined: Critical Ecosystem Partnership Fund web page, accessed August 29, 2020, at https://www.cepf.net/ our-work/biodiversity-hotspots/hotspots-defined.

Daehler, C.C., 1998, The taxonomic distribution of invasive angiosperm plants-Ecological insights and comparison to agricultural weeds: Biological Conservation, v. 84, no. 2 , p. $167-180$.

Dahl, T., 1990, Wetlands losses in the United States, 1780's to 1980's: Washington, D.C., U.S. Department of the Interior, Fish and Wildlife Service, $21 \mathrm{p}$.

Dale, V.H., Joyce, L.A., McNulty, S., Neilson, R.P., Ayres, M.P., Flannigan, M.D., Hanson, P.J., Irland, L.C., Lugo, A.E., Peterson, C.J., Simberloff, D., Swanson, F.J., Stocks, B.J., and Wotton, B.M., 2001, Climate change and forest disturbances: Bioscience, v. 51, no. 9, p. 723-734.

Dass, P., Houlton, B.Z., Wang, Y., and Warlind, D., 2018, Grasslands may be more reliable carbon sinks than forests in California: Environmental Research Letters, v. 13, no. 7, p. 074027, accessed February 13, 2021, at https://doi. org/10.1088/1748-9326/aacb39.

Davis, C.A., Churchwell, R.T., Fuhlendorf, S.D., Engle, D.M., and Hovick, T.J., 2016, Effect of pyric herbivory on source-sink dynamics in grassland birds: Journal of Applied Ecology, v. 53, no. 4, p. 1004-1012.

Davis, J., 1967, General map of natural vegetation of Florida: Gainesville, Fla., Institute of Food and Agricultural Sciences, University of Florida, Circular S-178, 1 sheet.

Davis, M., Chew, M., Hobbs, R., Lugo, A., Ewel, J., Vermeij, G., Brown, J., Rosenzweig, M., Gardener, M., Carroll, S., Thompson, K., Pickett, S., Stromberg, J., Tredici, P., Suding, K.N., Ehrenfeld, J.G., Philip Grime, J., Mascaro, J., and Briggs, J.C., 2011, Don't judge species on their origins: Nature, v. 474, no. 7350, p. 153-154.

Davis, M.A., 2003, Biotic globalization-Does competition from introduced species threaten biodiversity?: Bioscience, v. 53 , no. 5 , p. $481-489$.

Denney, D.A., Jameel, M.I., Bemmels, J.B., Rochford, M.E., and Anderson, J.T., 2020, Small spaces, big impacts - Contributions of micro-environmental variation to population persistence under climate change: AoB Plants, v. 12, no. 2, p. 1-21. 
Dobrowski, S., 2011, A climatic basis for microrefugia-The influence of terrain on climate: Global Change Biology, v. 17 , no. 2, p. 1022-1035.

Donders, T.H., de Boer, H.J., Finsinger, W., Grimm, E.C., Dekker, S.C., Reichart, G.J., and Wagner-Cremer, F., 2011, Impact of the Atlantic warm pool on precipitation and temperature in Florida during North Atlantic cold spells: Climate Dynamics, v. 36, no. 1-2, p. 109-118.

Dukes, J.S., and Mooney, H.A., 1999, Does global change increase the success of biological invaders?: Trends in Ecology \& Evolution, v. 14, no. 4, p. 135-139.

Engle, D.M., and Stritzke, J.F., 1995, Fire behavior and fire effects on eastern redcedar in hardwood leaf-litter fires: International Journal of Wildland Fire, v. 5, no. 3, p. 135-141.

Esri, 2020, ArcGIS living atlas of the World: Redlands, Calif., Esri online database, accessed August 28, 2020, at https:// livingatlas.arcgis.com/en/browse/\#d=2\&srt=name\&q=mobi owner\%3ANatureServe.

Estes, D., Brock, M., Homoya, M., and Dattilo, A., 2016, A guide to the grasslands of the Mid-South: Clarksville, Tenn., Natural Resources Conservation Service, Tennessee Valley Authority, Austin Peay State University, and the Botanical Research Institute of Texas, $28 \mathrm{p}$.

Fahrig, L., 2017, Ecological responses to habitat fragmentation per se: Annual Review of Ecology, Evolution, and Systematics, v. 48, no. 1, p. 1-23.

Fill, J.M., Platt, W.J., Welch, S.M., Waldron, J.L., and Mousseau, T.A., 2015, Updating models for restoration and management of fiery ecosystems: Forest Ecology and Management, v. 356, p. 54-63.

Fleishman, E., Noss, R.F., and Noon, B.R., 2006, Utility and limitations of species richness metrics for conservation planning: Ecological Indicators, v. 6, no. 3, p. 543-553.

Fletcher, R.J., Jr., Didham, R.K., Banks-Leite, C., Barlow, J., Ewers, R.M., Rosindell, J., Holt, R.D., Gonzalez, A., Pardini, R., Damschen, E.I., Melo, F.P.L., Ries, L., Prevedello, J.A., Tscharntke, T., Laurance, W.F., Lovejoy, T., and Haddad, N.M., 2018, Is habitat fragmentation good for biodiversity?: Biological Conservation, v. 226, p. 9-15.

Florida Natural Areas Inventory, 2010, Guide to the natural communities of Florida (2010 ed.): Tallahassee, Fla., Florida Natural Areas Inventory, $278 \mathrm{p}$.

Flory, S.L., Bauer, J., Phillips, R.P., and Clay, K., 2017, Effects of a non-native grass invasion decline over time: Journal of Ecology, v. 105, no. 6, p. 1475-1484.

Fridley, J., Stachowicz, J.J., Naeem, S., Sax, D., Seabloom, E., Smith, M., Stohlgren, T., Tilman, D., and Von Holle, B., 2007, The invasion paradox-Reconciling pattern and process in species invasions: Ecology, v. 88, no. 1, p. 3-17.
Frost, C., 1998, Presettlement fire frequency regimes of the United States - A first approximation, in Proceedings 20th Tall Timbers Fire Ecology Conference: Fire in ecosystem management: shifting the paradigm from suppression to prescription, May 7-10, 1996, Boise, Idaho: Tallahassee, Fla., Tall Timbers Research Station, p. 70-81.

Fuhlendorf, S.D., Engle, D.M., Kerby, J., and Hamilton, R., 2009, Pyric herbivory-Rewilding landscapes through the recoupling of fire and grazing: Conservation Biology, v. 23, no. 3 , p. 588-598.

Gagnon, P., and Platt, W., 2008, Multiple disturbances accelerate clonal growth in a potentially monodominant bamboo: Ecology, v. 89, no. 3, p. 612-618.

Graham, A., 1999, Late Cretaceous and Cenozoic history of North American vegetation, north of Mexico: New York, Oxford University Press, $370 \mathrm{p}$.

Grimm, E.C., Watts, W.A., Jacobson, G.L., Jr., Hansen, B.C.S., Almquist, H.R., and Dieffenbacher-Krall, A.C., 2006, Evidence for warm wet Heinrich events in Florida: Quaternary Science Reviews, v. 25, no. 17-18, p. 2197-2211.

Grimm, N.B., Chapin, F.S., III, Bierwagen, B., Gonzalez, P., Groffman, P.M., Luo, Y., Melton, F., Nadelhoffer, K., Pairis, A., Raymond, P.A., Schimel, J., and Williamson, C.E., 2013, The impacts of climate change on ecosystem structure and function: Frontiers in Ecology and the Environment, v. 11 , no. 9, p. 474-482.

Guerin, D.N., 1993, Oak dome clonal structure and fire ecology in a Florida longleaf pine dominated community: Bulletin of the Torrey Botanical Club, v. 120, no. 2, p. 107-114.

Haddad, N.M., Brudvig, L.A., Clobert, J., Davies, K.F., Gonzalez, A., Holt, R.D., Lovejoy, T.E., Sexton, J.O., Austin, M.P., Collins, C.D., Cook, W.M., Damschen, E.I., Ewers, R.M., Foster, B.L., Jenkins, C.N., King, A.J., Laurance, W.F., Levey, D.J., Margules, C.R., Melbourne, B.A., Nicholls, A.O., Orrock, J.L., Song, D.-X., and Townshend, J.R., 2015, Habitat fragmentation and its lasting impact on Earth's ecosystems: Science Advances, v. 1, no. 2, p. 1-10.

Haire, S.L., and McGarigal, K., 2010, Effects of landscape patterns of fire severity on regenerating ponderosa pine forests (Pinus ponderosa) in New Mexico and Arizona, USA: Landscape Ecology, v. 25, no. 7, p. 1055-1069.

Hanberry, B.B., Bragg, D.C., and Alexander, H.D., 2020, Open forest ecosystems-An excluded state: Forest Ecology and Management, v. 472, p. 118256, accessed February 13, 2021, at https://doi.org/10.1016/j.foreco.2020.118256.

Hannah, L., Flint, L., Syphard, A.D., Moritz, M.A., Buckley, L.B., and McCullough, I.M., 2014, Fine-grain modeling of species' response to climate change-Holdouts, steppingstones, and microrefugia: Trends in Ecology \& Evolution, v. 29 , no. 7, p. 390-397. 
Harrison, S., and Noss, R., 2017, Endemism hotspots are linked to stable climatic refugia: Annals of Botany, v. 119, no. 2, p. 207-214.

Heberling, J.M., and Isaac, B.L., 2017, Herbarium specimens as exaptations - New uses for old collections: American Journal of Botany, v. 104, no. 7, p. 963-965.

Heberling, J.M., and Isaac, B.L., 2018, iNaturalist as a tool to expand the research value of museum specimens: Applications in Plant Sciences, v. 6, no. 11, p. 1-8.

Hellmann, J.J., Byers, J.E., Bierwagen, B.G., and Dukes, J.S., 2008, Five potential consequences of climate change for invasive species: Conservation Biology, v. 22, no. 3, p. 534-543.

Hiers, J.K., Walters, J.R., Mitchell, R.J., Varner, J.M., Conner, L.M., Blanc, L.A., and Stowe, J., 2014, Ecological value of retaining pyrophytic oaks in longleaf pine ecosystems: Journal of Wildlife Management, v. 78, no. 3, p. 383-393.

Hill, J., and Barone, J., 2018, Southeastern grasslands-Biodiversity, ecology, and management: Tuscaloosa, Ala., University of Alabama Press, 344 p.

Jansson, R., 2003, Global patterns in endemism explained by past climatic change: Proceedings of the Royal Society B, Biological Sciences, v. 270, no. 1515, p. 583-590.

Jenkins, R., 1985, Information methods-Why the heritage programs work: Nature Conservancy News, v. 35, no. 6 , p. 21-23.

Kane, J.M., Varner, J.M., and Hiers, J.K., 2008, The burning characteristics of southeastern oaks - Discriminating fire facilitators from fire impeders: Forest Ecology and Management, v. 256, no. 12, p. 2039-2045.

Karl, T., Melillo, J., and Peterson, T., 2009, Global climate change impacts in the United States: New York, Cambridge University Press, 196 p.

Keeley, J.E., Pausas, J.G., Rundel, P.W., Bond, W.J., and Bradstock, R.A., 2011, Fire as an evolutionary pressure shaping plant traits: Trends in Plant Science, v. 16, no. 8, p. 406-411.

Keith, D.A., Rodríguez, J.P., Brooks, T.M., Burgman, M.A., Barrow, E.G., Bland, L., Comer, P.J., Franklin, J., Link, J., Mccarthy, M.A., Miller, R.M., Murray, N.J., Nel, J., Nicholson, E., Oliveira-Miranda, M.A., Regan, T.J., Rodríguez-Clark, K.M., Rouget, M., and Spalding, M.D., 2015, The IUCN red list of ecosystems-Motivations, challenges, and applications: Conservation Letters, v. 8, no. 3, p. 214-226.
Keith, D.A., Rodríguez, J.P., Rodríguez-Clark, K.M., Nicholson, E., Aapala, K., Alonso, A., Asmussen, M., Bachman, S., Basset, A., Barrow, E.G., Benson, J.S., Bishop, M.J., Bonifacio, R., Brooks, T.M., Burgman, M.A., Comer, P., Comín, F.A., Essl, F., Faber-Langendoen, D., Fairweather, P.G., Holdaway, R.J., Jennings, M., Kingsford, R.T., Lester, R.E., Nally, R.M., McCarthy, M.A., Moat, J., OliveiraMiranda, M.A., Pisanu, P., Poulin, B., Regan, T.J., Riecken, U., Spalding, M.D., and Zambrano-Martínez, S., 2013, Scientific foundations for an IUCN Red List of ecosystems: PLoS One, v. 8, no. 5, e62111, accessed February 13, 2001, at https://doi.org/10.1371/journal.pone.0062111.

Klinger, R., and Brooks, M., 2017, Alternative pathways to landscape transformation-Invasive grasses, burn severity and fire frequency in arid ecosystems: Journal of Ecology, v. 105 , no. 6 , p. 1521-1533.

Knight, R.R., Gain, W.S., and Wolfe, W.J., 2012, Modelling ecological flow regime-An example from the Tennessee and Cumberland River basins: Ecohydrology, v. 5, no. 5, p. $613-627$.

Kohl, M.T., Krausman, P.R., Kunkel, K., and Williams, D.M., 2013, Bison versus cattle-Are they ecologically synonymous?: Rangeland Ecology and Management, v. 66, no. 6, p. 721-731.

Kruckeberg, A., 1984, California serpentines-Flora, vegetation, geology, soils, and management problems: Berkeley, Calif., University of California Press, 196 p.

LANDFIRE, 2016, LANDFIRE remap (LF 2.0.0): LANDFIRE, Landscape Fire and Resource Management Planning Tools online database, accessed August 28, 2020, at https://www.landfire.gov/lf_remap.php.

Leger, E.A., and Goergen, E.M., 2017, Invasive Bromus tectorum alters natural selection in arid systems: Journal of Ecology, v. 105, no. 6, p. 1509-1520.

Lehmann, P., Ammunét, T., Barton, M., Battisti, A., Eigenbrode, S.D., Jepsen, J.U., Kalinkat, G., Neuvonen, S., Niemelä, P., Terblanche, J.S., Økland, B., and Björkman, C., 2020, Complex responses of global insect pests to climate warming: Frontiers in Ecology and the Environment, v. 18, no. 3, p. 141-150.

Limb, R.F., Fuhlendorf, S.D., Engle, D.M., Weir, J.R., Elmore, R.D., and Bidwell, T.G., 2011, Pyric-herbivory and cattle performance in grassland ecosystems: Rangeland Ecology and Management, v. 64, no. 6, p. 659-663.

Mandle, L., Bufford, J.L., Schmidt, I.B., and Daehler, C.C., 2011, Woody exotic plant invasions and fire-Reciprocal impacts and consequences for native ecosystems: Biological Invasions, v. 13, no. 8, p. 1815-1827. 
Menges, E.S., and Gordon, D.R., 2010, Should mechanical treatments and herbicides be used as fire surrogates to manage Florida's uplands? A review: Florida Scientist, v. 73, no. 1, p. 147-174.

Midgley, G.F., and Bond, W.J., 2015, Future of African terrestrial biodiversity and ecosystems under anthropogenic climate change: Nature Climate Change, v. 5, no. 9, p. 823-829.

Morelli, T.L., Barrows, C.W., Ramirez, A.R., Cartwright, J.M., Ackerly, D.D., Eaves, T.D., Ebersole, J.L., Krawchuk, M.A., Letcher, B.H., Mahalovich, M.F., Meigs, G.W., Michalak, J.L., Millar, C.I., Quiñones, R.M., Stralberg, D., and Thorne, J.H., 2020, Climate-change refugia-Biodiversity in the slow lane: Frontiers in Ecology and the Environment, v. 18 , no. 5, p. 228-234.

Morgan, G.S., and Emslie, S.D., 2010, Tropical and western influences in vertebrate faunas from the Pliocene and Pleistocene of Florida: Quaternary International, v. 217, no. 1-2, p. $143-158$.

Morgan, J.A., Lecain, D.R., Pendall, E., Blumenthal, D.M., Kimball, B.A., Carrillo, Y., Williams, D.G., Heisler-White, J., Dijkstra, F.A., and West, M., 2011, $\mathrm{C}_{4}$ grasses prosper as carbon dioxide eliminates desiccation in warmed semi-arid grassland: Nature, v. 476, no. 7359, p. 202-205.

Myers, R., and Ewel, J., eds., 1990, Ecosystems of Florida: Orlando, Fla., University of Central Florida Press, 765 p.

NatureServe, 2021, The map of biodiversity importance, accessed February 13, 2021, at https://www.natureserve.org/ conservation-tools/projects/map-biodiversity-importance.

Noss, R., 2001, Beyond Kyoto-Forest management in a time of rapid climate change: Conservation Biology, v. 15, no. 3 , p. $578-590$.

Noss, R., 2011, Between the devil and the deep blue seaFlorida's unenviable position with respect to sea level rise: Climatic Change, v. 107, no. 1, p. 1-16.

Noss, R., 2013, Forgotten grasslands of the south: Washington, D.C., Island Press, $320 \mathrm{p}$.

Noss, R., 2018, Fire ecology of Florida and the southeastern Coastal Plain: Gainesville, Fla., University Press of Florida, $358 \mathrm{p}$.

Noss, R., Csuti, B., and Groom, M., 2006a, Habitat fragmentation, in Groom, M., Meffe, G., and Carroll, R., eds., Principles of conservation biology ( $3 \mathrm{~d}$ ed.): Sunderland, Mass., Sinauer Associates, p. 213-251.

Noss, R., Franklin, J.F., Baker, W.L., Schoennagel, T., and Moyle, P.B., 2006b, Managing fire-prone forests in the western United States: Frontiers in Ecology and the Environment, v. 4, no. 9, p. 481-487.
Noss, R., Korosy, M., Breininger, D., Aldredge, J., and Bjork, R., 2008, An investigation of breeding and non-breeding season ecology, metapopulation dynamics, and recovery options for the Florida grasshopper sparrow (Ammodramus savannarum floridanus). Final report to the U.S. Fish and Wildlife Service, agreement no. 401815G03: Orlando, Fla., University of Central Florida, $97 \mathrm{p}$.

Noss, R., LaRoe, E., and Scott, J., 1995, Endangered ecosystems of the United States - A preliminary assessment of loss and degradation: Washington, D.C., U.S. Department of the Interior, $95 \mathrm{p}$.

Noss, R., O'Connell, M., and Murphy, D., 1997, The science of conservation planning-Habitat conservation under the Endangered Species Act: Washington, D.C., Island Press, $263 \mathrm{p}$.

Noss, R., Platt, W.J., Sorrie, B.A., Weakley, A.S., Means, D.B., Costanza, J., and Peet, R.K., 2015, How global biodiversity hotspots may go unrecognized-Lessons from the North American Coastal Plain: Diversity and Distributions, v. 21, no. 2, p. 236-244.

Noss, R., and Veldman, J., 2019, Grasslands (Pastizales), in Kormos, C., Raghav, S., Rodriguez, C., Mittermeier, R., Mackey, B., and Sechrest, W., eds., Nature's solutions to climate change (Soluciones de la naturaleza al cambio climatico): Qualicum Beach, BC, CEMEX, p. 139-149.

Ohio Invasive Plants Council, 2020, Ohio Invasive Plants Council: Ohio Invasive Plants Council website, accessed August 29, 2020, at https://www.oipc.info/.

Pausas, J.G., and Keeley, J.E., 2009, A burning story-The role of fire in the history of life: Bioscience, v. 59, no. 7, p. 593-601.

Pilkey, O., and Young, R., 2009, The rising sea: Washington, D.C., Island Press, 224 p.

Platt, W., Huffman, J., Slocum, M., and Beckage, B., 2006, Fire regimes and trees in Florida dry prairie landscapes, in Noss, R., ed., Land of fire and water-The Florida Dry Prairie Ecosystem, Florida Dry Prairie Conference, October 5-7, 2004, Proceedings: DeLeon Springs, Fla., E.O. Painter, p. 3-13.

Platt, W.J., and Gottschalk, R.M., 2001, Effects of exotic grasses on potential fine fuel loads in the groundcover of south Florida slash pine savannas: International Journal of Wildland Fire, v. 10, no. 2, p. 155-159.

Prasad, A., Iverson, L., Matthews, S., and Peters, M., 2007, A climate change atlas for 134 forest tree species of the Eastern United States: Delaware, Ohio, Northern Research Station, United States Department of Agriculture Forest Service online database, accessed August 28, 2020, at https://www.nrs.fs.fed.us/atlas/tree. 
Reemts, C.M., and Eidson, J.A., 2019, Choosing plant diversity metrics-A tallgrass prairie case study: Ecological Restoration, v. 37, no. 4, p. 233-245.

Reichard, S.H., and White, P., 2001, Horticulture as a pathway of invasive plant introductions in the United States: Bioscience, v. 51, no. 2, p. 103-113.

Reid, C.S., Faulkner, P.L., Macroberts, M.H., Macroberts, B.R., and Bordelon, M., 2010, Vascular flora and edaphic characteristics of saline prairies in Louisiana: Journal of the Botanical Research Institute of Texas, v. 4, no. 1, p. 357-379.

Ricciardi, A., and Simberloff, D., 2009, Assisted colonization is not a viable conservation strategy: Trends in Ecology \& Evolution, v. 24, no. 5, p. 248-253.

Rodríguez, J.P., Rodríguez-Clark, K.M., Baillie, J.E.M., Ash, N., Benson, J., Boucher, T., Brown, C., Burgess, N.D., Collen, B., Jennings, M., Keith, D.A., Nicholson, E., Revenga, C., Reyers, B., Rouget, M., Smith, T., Spalding, M., Taber, A., Walpole, M., Zager, I., and Zamin, T., 2011, Establishing IUCN Red List criteria for threatened ecosystems: Conservation Biology, v. 25, no. 1, p. 21-29.

Romps, D.M., Seeley, J.T., Vollaro, D., and Molinari, J., 2014, Projected increase in lightning strikes in the United States due to global warming: Science, v. 346, no. 6211, p. 851-854.

Ryan, K.C., Knapp, E.E., and Varner, J.M., 2013, Prescribed fire in North American forests and woodlands-History, current practice, and challenges: Frontiers in Ecology and the Environment, v. 11, no. 1, p. e15-e24, accessed February 14, 2021, at https://doi.org/10.1890/120329.

Samson, F., and Knopf, F., eds., 1996, Prairie conservationPreserving North America's most endangered ecosystem: Washington, D.C., Island Press, 351 p.

Samuelson, L.J., Stokes, T.A., and Johnsen, K.H., 2012, Ecophysiological comparison of 50-year-old longleaf pine, slash pine and loblolly pine: Forest Ecology and Management, v. 274, p. 108-115.

Savage, M., and Mast, J.N., 2005, How resilient are southwestern ponderosa pine forests after crown fires?: Canadian Journal of Forest Research, v. 35, no. 4, p. 967-977.

Sax, D.F., Stachowicz, J.J., Brown, J.H., Bruno, J.F., Dawson, M.N., Gaines, S.D., Grosberg, R.K., Hastings, A., Holt, R.D., Mayfield, M.M., O'Connor, M.I., and Rice, W.R., 2007, Ecological and evolutionary insights from species invasions: Trends in Ecology \& Evolution, v. 22, no. 9, p. 465-471.
Sears, P., 1981, Peninsula or archipelago?, in Stuckey, R., and Reese, K., eds., The prairie peninsula - In the shadow of Transeau, 6th North American Prairie Conference, The Ohio State University, August 1978, Proceedings: Ohio Biological Survey Notes 15, 2-3.

SECAS, 2020, Southeast Conservation Adaptation Strategy: Southeast Conservation Adaptation Strategy website, accessed August 29, 2020, at http://secassoutheast.org/.

SERNEC, 2020, Southeast Regional Network of Enterprise and Collections (SERNEC): Southeast Regional Network of Enterprise and Collections online database, accessed August 28, 2020, at https://sernecportal.org/portal/.

Slocum, M.G., Platt, W.J., Beckage, B., Orzell, S.L., and Taylor, W., 2010, Accurate quantification of seasonal rainfall and associated climate-wildfire relationships: Journal of Applied Meteorology and Climatology, v. 49, no. 12, p. 2559-2573.

Smith, D.R., Allan, N.L., McGowan, C.P., Szymanski, J.A., Oetker, S.R., and Bell, H.M., 2018, Development of a species status assessment process for decisions under the U.S. Endangered Species Act: Journal of Fish and Wildlife Management, v. 9, no. 1, p. 302-320.

Sorrie, B., and Weakley, A., 2001, Coastal Plain vascular plant endemics-Phytogeographic patterns: Castanea, v. 66, no. 1 , p. 50-82.

Southeastern Grasslands Initiative, 2020, The Southeastern Grasslands Initiative (SGI) works to conserve, restore, and promote native grasslands of all types throughout the Southeast: Southern Grasslands Initiative web page, accessed August 29, 2020, at https://www.segrasslands.org/.

Staver, A.C., Archibald, S., and Levin, S.A., 2011, The global extent and determinants of savanna and forest as alternative biome states: Science, v. 334, no. 6053, p. 230-232.

Stevens, J.T., and Beckage, B., 2009, Fire feedbacks facilitate invasion of pine savannas by Brazilian pepper (Schinus terebinthifolius): New Phytologist, v. 184, no. 2, p. 365-375.

Suen, J.P., and Eheart, J.W., 2006, Reservoir management to balance ecosystem and human needs-Incorporating the paradigm of the ecological flow regime: Water Resources Research, v. 42, no. 3, p. 1-9.

Swink, F., and Wilhelm, G., 1979, Plants of the Chicago region ( $3 \mathrm{~d}$ ed.): Lisle, Ill., Morton Arboretum, 936 p.

Terando, A.J., Costanza, J., Belyea, C., Dunn, R.R., McKerrow, A., and Collazo, J., 2014, The southern megalopolis-Using the past to predict the future of urban sprawl in the Southeast U.S.: PLoS One, v. 9, no. 7, p. e102261, accessed February 14, 2021, at https://doi.org/10.1371/journal.pone.0102261. 
The World Café, 2020, World Café Method: World Café web page, accessed August 28, 2020, at http://www.theworldcafe.com/key-concepts-resources/world-cafe-method/.

Transeau, E., 1935, The prairie peninsula: Ecology, v. 16, no. 3, p. $423-437$.

Trisos, C.H., Merow, C., and Pigot, A.L., 2020, The projected timing of abrupt ecological disruption from climate change: Nature, v. 580, no. 7804, p. 496-501.

Tyndall, R., and Hull, J., 1999, Vegetation, flora, and plant physiological ecology of serpentine barrens of eastern North America, in Anderson, R.C., Fralish, J.S., and Baskin, J.M., Savannas, barrens, and rock outcrop plant communities of North America: Cambridge, United Kingdom, Cambridge University Press, p. 67-82.

Ulrey, C., Quintana-Ascencio, P.F., Kauffman, G., Smith, A.B., and Menges, E.S., 2016, Life at the top-Longterm demography, microclimatic refugia, and responses to climate change for a high-elevation southern Appalachian endemic plant: Biological Conservation, v. 200 , p. $80-92$.

U.S. Environmental Protection Agency, 2013, Level III and IV ecoregions of the continental United States: Corvallis, Oreg., U.S. Environmental Protection Agency, National Health and Environmental Effects Research Laboratory, accessed August 2020 at https://www.epa.gov/ecoresearch/level-iii-and-iv-ecoregions-continental-unitedstates.

U.S. Fish and Wildlife Service, 2016, Species Status Assessment Framework-An integrated framework for conservation: U.S. Fish and Wildlife Service web page, accessed August 28, 2020, at https://www.fws.gov/endangered/ improving_esa/pdf/SSA_Fact_Sheet-August_2016.pdf.

U.S. Global Change Research Program [USGCRP], 2017, Climate science special report-Fourth National Climate Assessment, v. I (Wuebbles, D., Fahey, D., Hibbard, K., Dokken, D., Stewart, B., and Maycock, T., eds.): Washington, D.C., U.S. Global Change Research Program, 470 p.

U.S. Global Change Research Program [USGCRP], 2018, Climate science special report-Fourth National Climate Assessment, v. II: Washington, D.C., U.S. Global Change Research Program, 1,515 p.

U.S. National Vegetation Classification [USNVC], 2019, United States National Vegetation Classification database, V2.03: Washington, DC, Federal Geographic Data Committee, Vegetation Subcommittee, accessed February 13, 2021 at http://usnvc.org/.
Varner, J.M., Gordon, D.R., Putz, F.E., and Hiers, J.K., 2005, Restoring fire to long-unburned Pinus palustris ecosystems-Novel fire effects and consequences for longunburned ecosystems: Restoration Ecology, v. 13, no. 3, p. 536-544.

VegBank, 2020, VegBank: Ecological Society of America, Panel on Vegetation Classification online database, accessed August 29, 2020, at http://vegbank.org/vegbank/index.jsp.

Veldman, J.W., Overbeck, G.E., Negreiros, D., Mahy, G., Le Stradic, S., Fernandes, G.W., Durigan, G., Buisson, E., Putz, F.E., and Bond, W.J., 2015, Where tree planting and forest expansion are bad for biodiversity and ecosystem services: Bioscience, v. 65, no. 10, p. 1011-1018.

Walck, J.L., Baskin, J.M., and Baskin, C.C., 1999, Effects of competition from introduced plants on establishment, survival, growth and reproduction of the rare plant Solidago shortii (Asteraceae): Biological Conservation, v. 88, no. 2, p. 213-219.

Walck, J.L., Hidayati, S.N., Dixon, K.W., Thompson, K., and Poschlod, P., 2011, Climate change and plant regeneration from seed: Global Change Biology, v. 17, no. 6, p. $2145-2161$.

Walker, J., and Peet, R., 1984, Composition and species diversity of pine-wiregrass savannas of the Green Swamp, North Carolina: Vegetatio, v. 55, no. 3, p. 163-179.

Watson, J., Keith, D., Strassburg, B., Venter, O., Williams, B., and Nicholson, E., 2020, Set a global target for ecosystems: Nature, v. 578, no. 7795 , p. 360-362.

Webb, S., 1990, Historical biogeography, in Myers, R., and Ewel, J., eds., Ecosystems of Florida: Orlando, Fla., University of Central Florida Press, p. 10-100.

Weigl, P.D., and Knowles, T.W., 2014, Temperate mountain grasslands-A climate-herbivore hypothesis for origins and persistence: Biological Reviews, v. 89, no. 2, p. 466-476.

Westerling, A.L., Hidalgo, H.G., Cayan, D.R., and Swetnam, T.W., 2006, Warming and earlier spring increase western U.S. forest wildfire activity: Science, v. 313, no. 5789, p. $940-943$.

Wintle, B., Kujala, H., Whitehead, A., Moilanen, A., Bekessy, S., and Kukkala, A., 2018, Size isn't everything-The importance of small habitat patches when planning the conservation of species in fragmented landscapes, in 5th European Congress of Conservation Biology, Jyvaskyla, Finland, June 12-15, 2018: Society for Conservation Biology, accessed February 14, 2021, at https://doi.org/10.17011/ conference/eccb2018/108691. 



\section{Glossary}

adventive species a species that has arrived in a new locality; it may or may not have had help from humans as an introduced species.

afforestation the process of planting trees, or sowing tree seeds, to create a forest.

assisted colonization the intentional relocation of a species in decline to a habitat where it can persist.

candidate species plants and animals for which the U.S. Fish and Wildlife Service (USFWS) has sufficient information on their biological status and threats to propose them as endangered or threatened under the Endangered Species Act (ESA), but for which development of a proposed listing regulation is precluded by other higher priority listing activities.

climate envelope model a type of species distribution model that describes relationships between species occurrences and bioclimate variables (such as temperature and precipitation) to define a species climate niche (envelope). Relationships derived from contemporary data can be projected to the future using estimates of anticipated climate change.

edaphic grasslands grasslands that occur primarily due to soil type or conditions, such as shallow or very rocky soils.

endemic a species that is native and restricted to a certain place.

Floristic Quality Assessment a standardized assessment method that calculates a numerical index reflecting the quality of native plant communities for a given area.

functional connectivity defined for plants as the effective dispersal of propagules or pollen among habitat patches in a landscape.

global biodiversity hotspot a biogeographic region having at least 1,500 endemic plant species which has lost at least 70 percent of its original vegetation, according to the definition from the Critical Ecosystem Partnership Fund (2020). marl prairie a specialized form of prairie that occurs on thin, calcitic soil that has accumulated over limestone bedrock.

microchipping a process of producing wood chips between $1 / 4$ and $3 / 8$ inches in length, produced in woods as a component of forest harvesting, for use in paper or energy production.

microrefugia small area(s) sheltered from broader-scale environmental instabilities over time, in which small populations of organisms can survive outside their main distributions.

phenophase mismatch a situation in which altered phenology caused by climate change disrupts time-sensitive relationships - such as migration, breeding and predation — which may in turn alter the rates of reproduction and survival, leading some populations to decline and others to increase in abundance.

pyric herbivory herbivory promoted through the use of fire.

redundancy a factor considered in the Species Status Assessment (SSA) process; ability of a species to persist through stochastic disturbance events or climate change.

representation a factor considered in the SSA process; representation of all geographic or genetically distinct populations.

resiliency a factor considered in the SSA process; multiple populations conserved to spread the risk of stochastic events among multiple populations or areas.

Species Status Assessment (SSA) an analytical approach used by the USFWS, designed to provide decision makers with information on the current and projected future biological status of species that are listed, candidate, or proposed for listing under the ESA.

World Café a structured conversational process for knowledge sharing among multiple groups of participants who build on each other's discussions. 



\section{Appendix 1. Grassland Ecosystems of the Southeastern United States}

NatureServe ecological systems that qualify as grasslands in the southeastern United States (see the map in fig. 2) are provided in table 1.1. Note that this includes all of the ecological systems that represent grassland systems or that include vegetation associations that meet the definition of grasslands defined in box 1. For some systems, there are component communities that could be split out as types of grasslands, while other examples of the system may exist in nongrassland component communities such as forests or swamps. 
Table 1.1. NatureServe ecological systems that qualify as grasslands in the southeastern United States. The list is divided according to the United States National Vegetation Classification (USNVC, 2019), with the following hierarchical levels shown: formation (L3), macrogroup (L5), and group (L6). The ecological system code and geographic range for each system are from NatureServe Explorer (https://explorer.natureserve.org/). In instances where a system is suspected or probable for a State, but not documented with certainty, the State abbreviation is followed by a question mark (for example, TN?). For ecological systems with geographic ranges partially within the southeastern United States that also extend into other States of the United States or Mexico, abbreviations for those additional States are included as well.

[FL, Florida; GA, Georgia; NC, North Carolina; SC, South Carolina; LA, Louisiana; TX, Texas; VA, Virginia; AL, Alabama; MS, Mississippi; OK, Oklahoma; AR, Arkansas; MO, Missouri; TN, Tennessee; KS, Kansas; MD, Maryland; PA, Pennsylvania; WV, West Virginia; KY, Kentucky; NY, New York; OH, Ohio; CT, Connecticut; MA, Massachusetts; ME, Maine; NH, New Hampshire; NJ, New Jersey; RI, Rhode Island; VT, Vermont; DE, Delaware; IN, Indiana; WI, Wisconsin; MXCOA, Mexican State of Coahuila; MXNLE, Mexican State of Nuevo León; MXTAM, Mexican State of Tamaulipas]

\begin{tabular}{|c|c|c|c|}
\hline USNVC classification & $\begin{array}{l}\text { Ecological } \\
\text { system code }\end{array}$ & Ecological system name & Geographic range \\
\hline Formation: & \multicolumn{3}{|c|}{ 1.B.1 Warm Temperate Forest \& Woodland } \\
\hline Group: & \multicolumn{3}{|c|}{ South Florida Slash Pine Rockland } \\
\hline Ecological system & CES411.367 & South Florida Pine Rockland & FL \\
\hline Ecological system & CES203.284 & Florida Longleaf Pine Sandhill & FL \\
\hline Ecological system & CES203.497 & Southern Atlantic Coastal Plain Xeric River Dune & GA \\
\hline Ecological system & CES203.891 & $\begin{array}{l}\text { West Gulf Coastal Plain Stream Terrace Sandyland Longleaf Pine } \\
\text { Woodland }\end{array}$ & LA?, TX \\
\hline Ecological system & CES203.496 & East Gulf Coastal Plain Interior Upland Longleaf Pine Woodland & AL, FL, GA, LA, MS \\
\hline Group: & \multicolumn{3}{|c|}{ Mesic Longleaf Pine Flatwoods - Spodosol Woodland } \\
\hline Ecological system & CES203.375 & East Gulf Coastal Plain Near-Coast Pine Flatwoods & AL, FL, GA, LA, MS \\
\hline Ecological system & CES203.382 & Central Florida Pine Flatwoods & FL \\
\hline Ecological system & CES411.381 & South Florida Pine Flatwoods & FL \\
\hline Group: & \multicolumn{3}{|c|}{ Wet-Mesic Longleaf Pine Open Woodland } \\
\hline Ecological system & CES203.191 & West Gulf Coastal Plain Wet Longleaf Pine Savanna and Flatwoods & LA, TX \\
\hline Ecological system & CES203.265 & $\begin{array}{l}\text { Central Atlantic Coastal Plain Wet Longleaf Pine Savanna and } \\
\text { Flatwoods }\end{array}$ & $\mathrm{NC}, \mathrm{SC}, \mathrm{VA}$ \\
\hline Ecological system & CES303.660 & Edwards Plateau Limestone Savanna and Woodland & OK, TX \\
\hline Formation: & \multicolumn{3}{|c|}{ 1.B.2 Cool Temperate Forest \& Woodland } \\
\hline Macrogroup: & \multicolumn{3}{|c|}{ Southern \& South-Central Oak - Pine Forest \& Woodland } \\
\hline Group: & \multicolumn{3}{|c|}{ South-Central Interior Shortleaf Pine - Oak Forest \& Woodland } \\
\hline Ecological system & CES202.313 & Ozark-Ouachita Shortleaf Pine-Oak Forest and Woodland & $\mathrm{AR}, \mathrm{MO}, \mathrm{OK}$ \\
\hline Ecological system & CES202.319 & Southeastern Interior Longleaf Pine Woodland & $\mathrm{AL}, \mathrm{GA}, \mathrm{NC}, \mathrm{SC}$ \\
\hline Ecological system & CES202.325 & Ozark-Ouachita Shortleaf Pine-Bluestem Woodland & $\mathrm{AR}, \mathrm{MO}, \mathrm{OK}$ \\
\hline
\end{tabular}


Table 1.1. NatureServe ecological systems that qualify as grasslands in the southeastern United States. The list is divided according to the United States National Vegetation Classification (USNVC, 2019), with the following hierarchical levels shown: formation (L3), macrogroup (L5), and group (L6). The ecological system code and geographic range for each system are from NatureServe Explorer (https://explorer.natureserve.org/). In instances where a system is suspected or probable for a State, but not documented with certainty, the State abbreviation is followed by a question mark (for example, TN?). For ecological systems with geographic ranges partially within the southeastern United States that also extend into other States of the United States or Mexico, abbreviations for those additional States are included as well.-Continued

[FL, Florida; GA, Georgia; NC, North Carolina; SC, South Carolina; LA, Louisiana; TX, Texas; VA, Virginia; AL, Alabama; MS, Mississippi; OK, Oklahoma; AR, Arkansas; MO, Missouri; TN, Tennessee; KS, Kansas; MD, Maryland; PA, Pennsylvania; WV, West Virginia; KY, Kentucky; NY, New York; OH, Ohio; CT, Connecticut; MA, Massachusetts; ME, Maine; NH, New Hampshire; NJ, New Jersey; RI, Rhode Island; VT, Vermont; DE, Delaware; IN, Indiana; WI, Wisconsin; MXCOA, Mexican State of Coahuila; MXNLE, Mexican State of Nuevo León; MXTAM, Mexican State of Tamaulipas]

\begin{tabular}{|c|c|c|c|}
\hline USNVC classification & $\begin{array}{l}\text { Ecological } \\
\text { system code }\end{array}$ & Ecological system name & Geographic range \\
\hline Formation: & \multicolumn{3}{|c|}{ 1.B.2 Cool Temperate Forest \& Woodland-Continued } \\
\hline Group: & \multicolumn{3}{|c|}{ South-Central Interior Shortleaf Pine - Oak Forest \& Woodland-Continued } \\
\hline Ecological system & CES203.506 & East Gulf Coastal Plain Interior Shortleaf Pine-Oak Forest & AL, LA, MS, TN? \\
\hline Group: & \multicolumn{3}{|c|}{ Western Gulf Coastal Plain Pine - Oak Forest \& Woodland } \\
\hline Ecological system & CES203.056 & $\begin{array}{l}\text { West Gulf Coastal Plain Sandhill Oak and Shortleaf Pine Forest and } \\
\text { Woodland }\end{array}$ & AR, LA, TX \\
\hline Ecological system & CES205.896 & Bastrop Lost Pines Forest and Woodland & TX \\
\hline Formation: & \multicolumn{3}{|c|}{ 1.B.3 Temperate Flooded \& Swamp Forest } \\
\hline Macrogroup: & \multicolumn{3}{|c|}{ Pond-cypress Basin Swamp } \\
\hline Group: & \multicolumn{3}{|c|}{ Pond-cypress Basin Swamp } \\
\hline Ecological system & CES203.245 & Atlantic Coastal Plain Clay-Based Carolina Bay Wetland & $\mathrm{GA}, \mathrm{NC}, \mathrm{SC}$ \\
\hline Ecological system & CES411.290 & South Florida Dwarf Cypress Savanna & FL \\
\hline Formation: & \multicolumn{3}{|c|}{ 2.B.2 Temperate Grassland \& Shrubland } \\
\hline Macrogroup: & \multicolumn{3}{|c|}{ Central Lowlands Tallgrass Prairie } \\
\hline Group: & \multicolumn{3}{|c|}{ Blackland \& Coastal Tallgrass Prairie } \\
\hline Ecological system & CES203.550 & Texas-Louisiana Coastal Prairie & LA, TX \\
\hline Ecological system & CES303.655 & Edwards Plateau Carbonate Glade and Barrens & $\mathrm{TX}$ \\
\hline Macrogroup: & \multicolumn{3}{|c|}{ Appalachian Rocky Felsic \& Mafic Scrub \& Grassland } \\
\hline Group: & \multicolumn{3}{|c|}{ Southern Appalachian Grass Bald } \\
\hline Ecological system & CES202.294 & Southern Appalachian Grass and Shrub Bald & $\begin{array}{l}\text { GA, KY, NC, TN, VA, } \\
\text { WV }\end{array}$ \\
\hline Group: & \multicolumn{3}{|c|}{ Appalachian Mafic Barrens } \\
\hline Ecological system & CES202.328 & Southern Piedmont Glade and Barrens & $\mathrm{AL}, \mathrm{GA}, \mathrm{NC}, \mathrm{SC}, \mathrm{VA}$ \\
\hline
\end{tabular}


Table 1.1. NatureServe ecological systems that qualify as grasslands in the southeastern United States. The list is divided according to the United States National Vegetation Classification (USNVC, 2019), with the following hierarchical levels shown: formation (L3), macrogroup (L5), and group (L6). The ecological system code and geographic range for each system are from NatureServe Explorer (https://explorer.natureserve.org/). In instances where a system is suspected or probable for a State, but not documented with certainty, the State abbreviation is followed by a question mark (for example, TN?). For ecological systems with geographic ranges partially within the southeastern United States that also extend into other States of the United States or Mexico, abbreviations for those additional States are included as well.-Continued

[FL, Florida; GA, Georgia; NC, North Carolina; SC, South Carolina; LA, Louisiana; TX, Texas; VA, Virginia; AL, Alabama; MS, Mississippi; OK, Oklahoma; AR, Arkansas; MO, Missouri; TN, Tennessee; KS, Kansas; MD, Maryland; PA, Pennsylvania; WV, West Virginia; KY, Kentucky; NY, New York; OH, Ohio; CT, Connecticut; MA, Massachusetts; ME, Maine; NH, New Hampshire; NJ, New Jersey; RI, Rhode Island; VT, Vermont; DE, Delaware; IN, Indiana; WI, Wisconsin; MXCOA, Mexican State of Coahuila; MXNLE, Mexican State of Nuevo León; MXTAM, Mexican State of Tamaulipas]

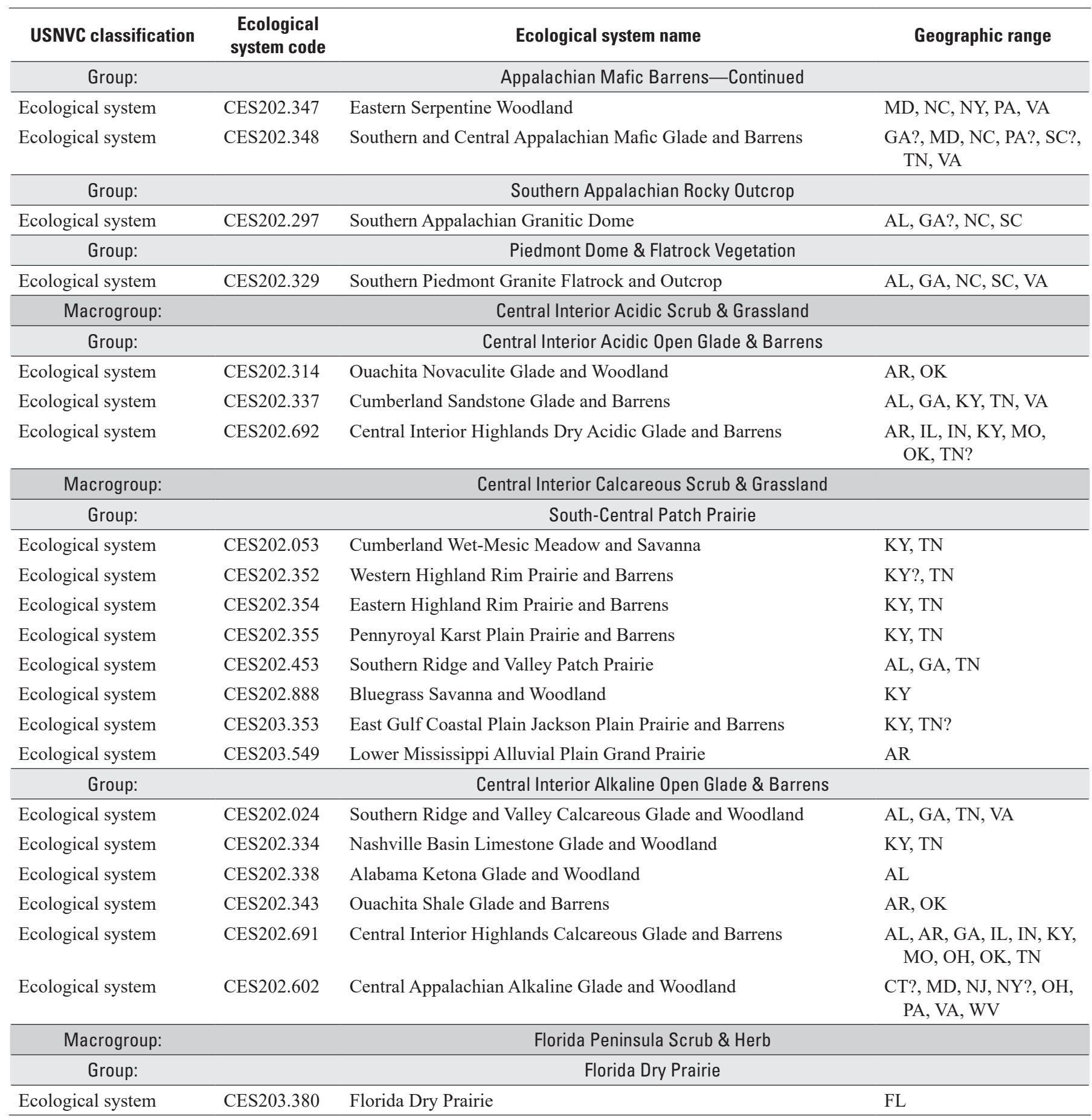


Table 1.1. NatureServe ecological systems that qualify as grasslands in the southeastern United States. The list is divided according to the United States National Vegetation Classification (USNVC, 2019), with the following hierarchical levels shown: formation (L3), macrogroup (L5), and group (L6). The ecological system code and geographic range for each system are from NatureServe Explorer (https://explorer.natureserve.org/). In instances where a system is suspected or probable for a State, but not documented with certainty, the State abbreviation is followed by a question mark (for example, TN?). For ecological systems with geographic ranges partially within the southeastern United States that also extend into other States of the United States or Mexico, abbreviations for those additional States are included as well.-Continued

[FL, Florida; GA, Georgia; NC, North Carolina; SC, South Carolina; LA, Louisiana; TX, Texas; VA, Virginia; AL, Alabama; MS, Mississippi; OK, Oklahoma; AR, Arkansas; MO, Missouri; TN, Tennessee; KS, Kansas; MD, Maryland; PA, Pennsylvania; WV, West Virginia; KY, Kentucky; NY, New York; OH, Ohio; CT, Connecticut; MA, Massachusetts; ME, Maine; NH, New Hampshire; NJ, New Jersey; RI, Rhode Island; VT, Vermont; DE, Delaware; IN, Indiana; WI, Wisconsin; MXCOA, Mexican State of Coahuila; MXNLE, Mexican State of Nuevo León; MXTAM, Mexican State of Tamaulipas]

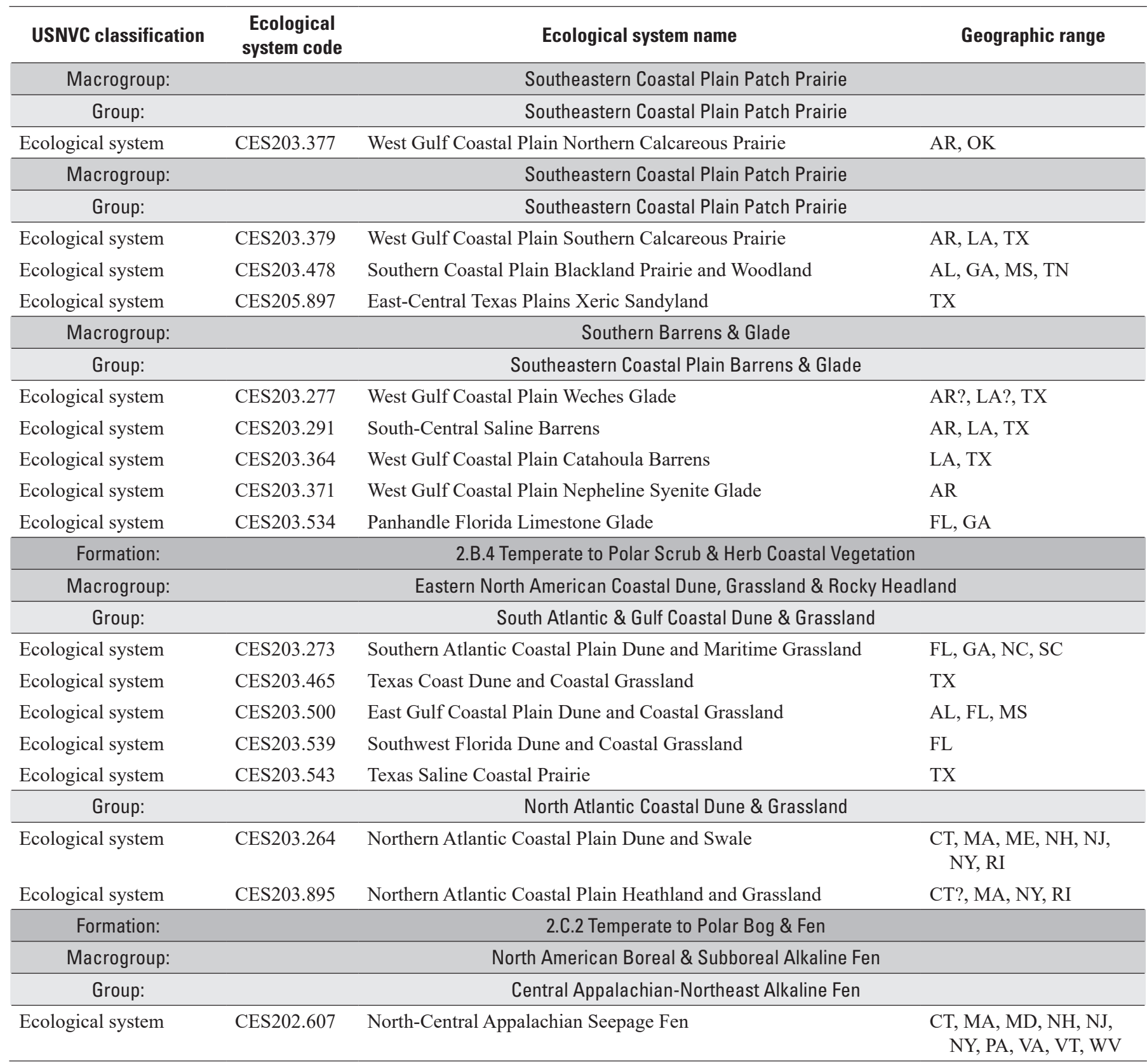


Table 1.1. NatureServe ecological systems that qualify as grasslands in the southeastern United States. The list is divided according to the United States National Vegetation Classification (USNVC, 2019), with the following hierarchical levels shown: formation (L3), macrogroup (L5), and group (L6). The ecological system code and geographic range for each system are from NatureServe Explorer (https://explorer.natureserve.org/). In instances where a system is suspected or probable for a State, but not documented with certainty, the State abbreviation is followed by a question mark (for example, TN?). For ecological systems with geographic ranges partially within the southeastern United States that also extend into other States of the United States or Mexico, abbreviations for those additional States are included as well.-Continued

[FL, Florida; GA, Georgia; NC, North Carolina; SC, South Carolina; LA, Louisiana; TX, Texas; VA, Virginia; AL, Alabama; MS, Mississippi; OK, Oklahoma; AR, Arkansas; MO, Missouri; TN, Tennessee; KS, Kansas; MD, Maryland; PA, Pennsylvania; WV, West Virginia; KY, Kentucky; NY, New York; OH, Ohio; CT, Connecticut; MA, Massachusetts; ME, Maine; NH, New Hampshire; NJ, New Jersey; RI, Rhode Island; VT, Vermont; DE, Delaware; IN, Indiana; WI, Wisconsin; MXCOA, Mexican State of Coahuila; MXNLE, Mexican State of Nuevo León; MXTAM, Mexican State of Tamaulipas]

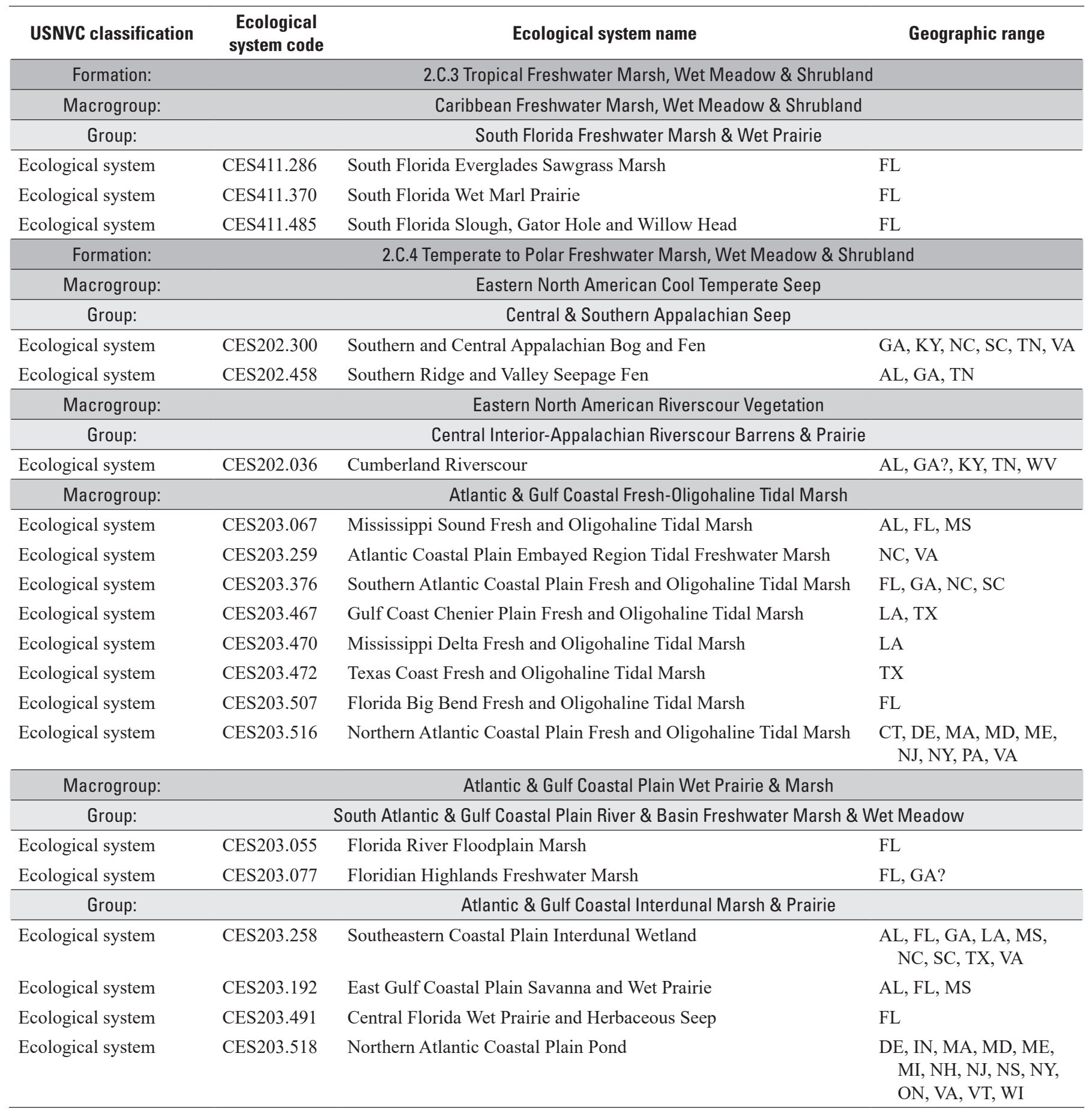


Table 1.1. NatureServe ecological systems that qualify as grasslands in the southeastern United States. The list is divided according to the United States National Vegetation Classification (USNVC, 2019), with the following hierarchical levels shown: formation (L3), macrogroup (L5), and group (L6). The ecological system code and geographic range for each system are from NatureServe Explorer (https://explorer.natureserve.org/). In instances where a system is suspected or probable for a State, but not documented with certainty, the State abbreviation is followed by a question mark (for example, TN?). For ecological systems with geographic ranges partially within the southeastern United States that also extend into other States of the United States or Mexico, abbreviations for those additional States are included as well.-Continued

[FL, Florida; GA, Georgia; NC, North Carolina; SC, South Carolina; LA, Louisiana; TX, Texas; VA, Virginia; AL, Alabama; MS, Mississippi; OK, Oklahoma; AR, Arkansas; MO, Missouri; TN, Tennessee; KS, Kansas; MD, Maryland; PA, Pennsylvania; WV, West Virginia; KY, Kentucky; NY, New York; OH, Ohio; CT, Connecticut; MA, Massachusetts; ME, Maine; NH, New Hampshire; NJ, New Jersey; RI, Rhode Island; VT, Vermont; DE, Delaware; IN, Indiana; WI, Wisconsin; MXCOA, Mexican State of Coahuila; MXNLE, Mexican State of Nuevo León; MXTAM, Mexican State of Tamaulipas]

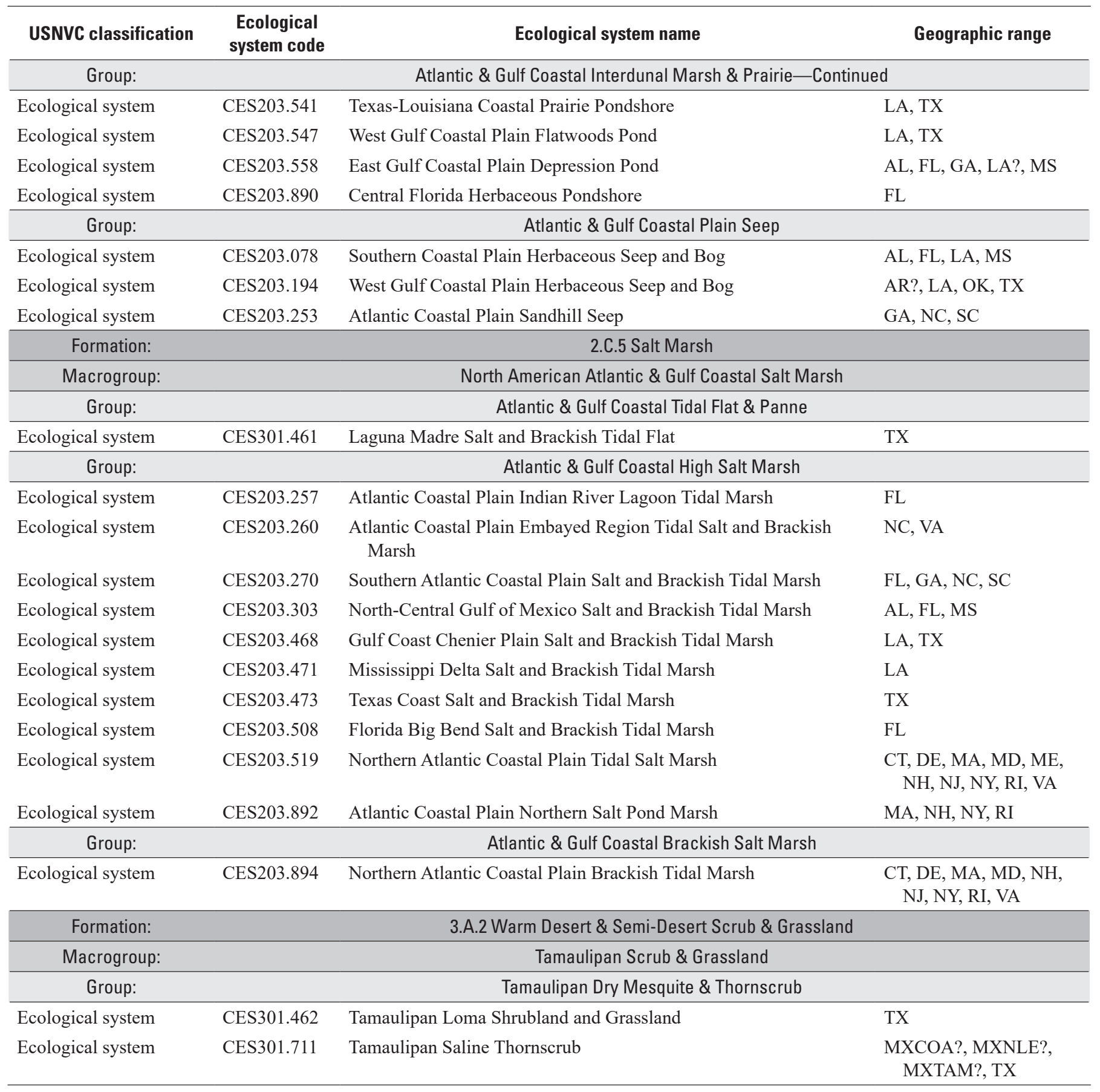


Table 1.1. NatureServe ecological systems that qualify as grasslands in the southeastern United States. The list is divided according to the United States National Vegetation Classification (USNVC, 2019), with the following hierarchical levels shown: formation (L3), macrogroup (L5), and group (L6). The ecological system code and geographic range for each system are from NatureServe Explorer (https://explorer.natureserve.org/). In instances where a system is suspected or probable for a State, but not documented with certainty, the State abbreviation is followed by a question mark (for example, TN?). For ecological systems with geographic ranges partially within the southeastern United States that also extend into other States of the United States or Mexico, abbreviations for those additional States are included as well.-Continued

[FL, Florida; GA, Georgia; NC, North Carolina; SC, South Carolina; LA, Louisiana; TX, Texas; VA, Virginia; AL, Alabama; MS, Mississippi; OK, Oklahoma; AR, Arkansas; MO, Missouri; TN, Tennessee; KS, Kansas; MD, Maryland; PA, Pennsylvania; WV, West Virginia; KY, Kentucky; NY, New York; OH, Ohio; CT, Connecticut; MA, Massachusetts; ME, Maine; NH, New Hampshire; NJ, New Jersey; RI, Rhode Island; VT, Vermont; DE, Delaware; IN, Indiana; WI, Wisconsin; MXCOA, Mexican State of Coahuila; MXNLE, Mexican State of Nuevo León; MXTAM, Mexican State of Tamaulipas]

\begin{tabular}{|c|c|c|c|}
\hline USNVC classification & $\begin{array}{l}\text { Ecological } \\
\text { system code }\end{array}$ & Ecological system name & Geographic range \\
\hline Group: & & Tamaulipan Dry Mesquite \& Thornscrub-Continued & \\
\hline Group: & & Tamaulipan Dry Grassland & \\
\hline Ecological system & CES301.985 & Tamaulipan Savanna Grassland & $\begin{array}{l}\text { MXCOA, MXNLE, } \\
\text { MXTAM, TX }\end{array}$ \\
\hline Ecological system & CES301.989 & Tamaulipan Caliche Grassland & MXTAM, TX \\
\hline Ecological system & CES301.717 & Tamaulipan Saline Lake & $\begin{array}{l}\text { MXNLE?, MXTAM?, } \\
\quad \text { TX }\end{array}$ \\
\hline
\end{tabular}




\section{Appendix 2. Southeastern Climate and Grasslands Workshop: Summary of Survey Results}

To provide workshop participants with an overview of how experts view various issues surrounding native grasslands in the Southeast, we conducted an online survey approximately 1 week prior to the workshop. Most people who attended the workshop supplied responses to the survey, and additional responses were received from other invited scientists and policy staff who could not attend. The results summarized below were presented at the outset of the workshop.

\section{Respondents}

We received a maximum of 39 responses on most questions, from the following mix of respondents (responses reflect dual roles held by some):

- 26 Federal and State agency representatives

- 10 nongovernmental organization (NGO) representatives

- 5 university representatives

- 5 in other categories, such as retired or consultant

Of the 39 total respondents, 52.5 percent were researchers or scientists, with 22.5 percent working in natural resource management, 7.5 percent in policy and communications, and the remaining 17.5 percent comprising a mix of natural heritage, Endangered Species Act section 6, listing and recovery, and other program coordinators and managers. Two-thirds of respondents worked in or were affiliated with institutions or work units that actively manage grassland species and habitats.

\section{Top Messages}

The top messages provided by this survey are summarized below, along with a graphic summary of each of these questions provided in the final section for greater detail.

Inventory and monitoring are the most used grassland management tools (fig. 2.1), followed by

- Prescribed burns

- Targeted removal of woody species

- Control of invasive species

Development and urban sprawl are perceived as the top threats to grasslands (fig. 2.2), followed by

- Woody encroachment

- Invasive species

- Agricultural conversion

- Lack of public support

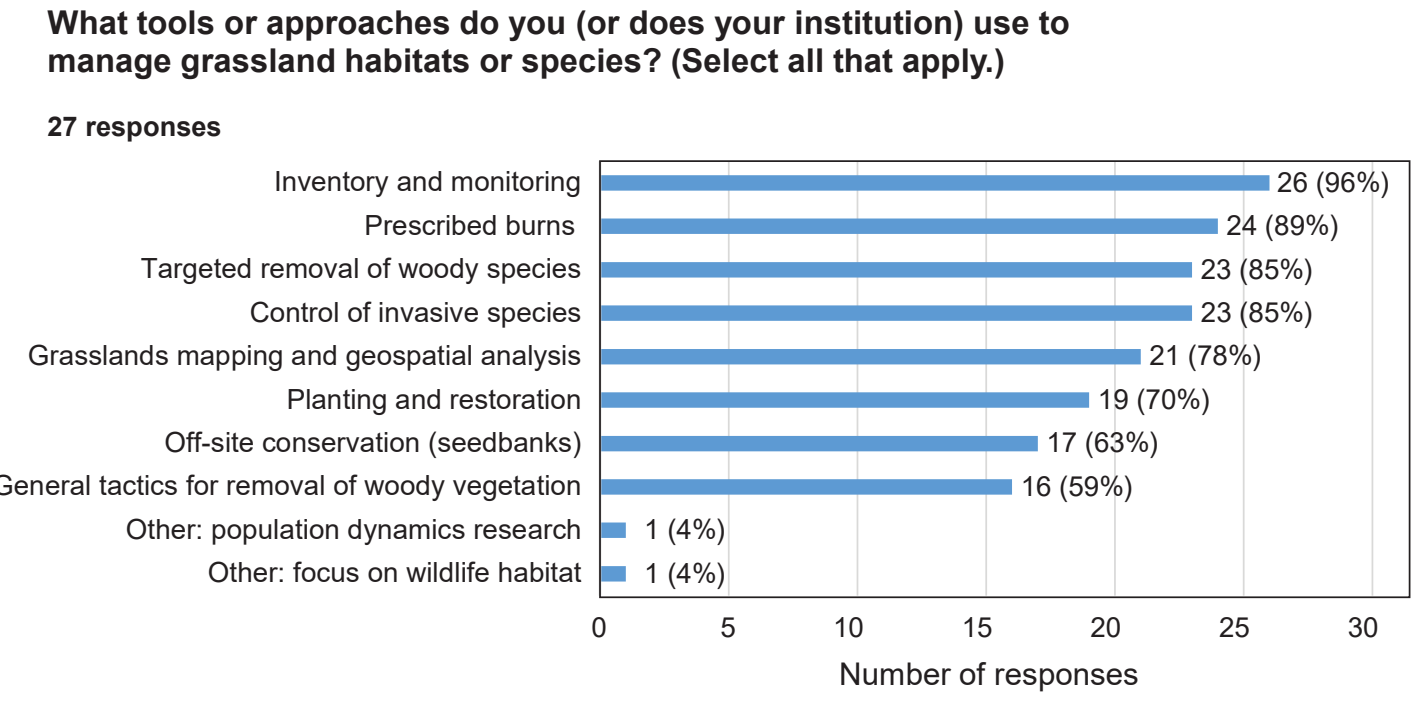

Figure 2.1. Grassland management tools and approaches identified by survey respondents. 


\begin{abstract}
What do you feel are the biggest risks to grassland species and habitats in the Southeast? (Select all that apply.)
\end{abstract}

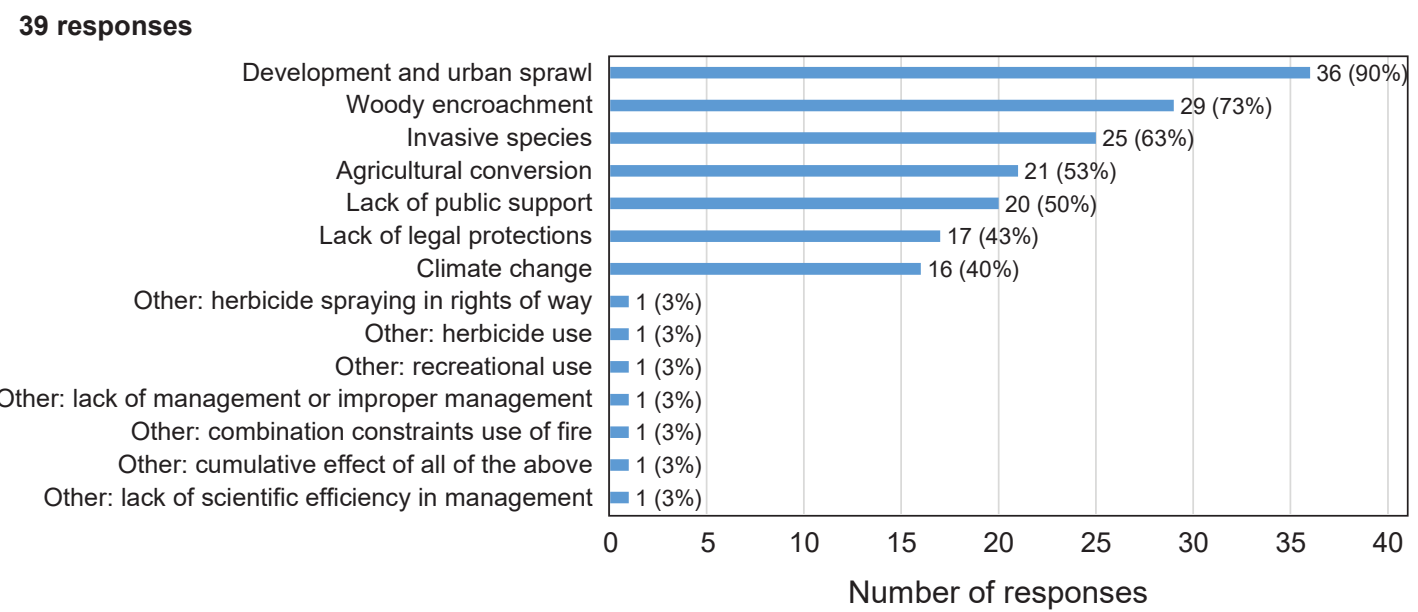

Figure 2.2. Top risks or threats to grasslands identified by survey respondents.

Increased awareness of the issues surrounding native grasslands is perceived as most needed to increase public support for their conservation (fig. 2.3), followed by

- Attitudes that support grassland conservation

- Increased knowledge and understanding of issues

The biggest perceived barrier to effective grassland management is limited funding (fig. 2.4), followed by

- Limited staff and personnel time

- Limited or outdated scientific information

- Challenges translating science into management

- Lack of public awareness and support

Grassland mapping and research on connectivityincluding historical extent-is most needed to better support management of grassland species and habitats (fig. 2.5), followed by

- The role of fire and considerations for prescribed fire

- Climate change, including changing hydrology and soil moisture

- Research and inventories of individual species of concern

\section{Discussion Responses}

Finally, the survey provided respondents with the opportunity to add to or explain in more detail their survey responses. More than 20 experts supplied comments, which are too lengthy and wide ranging to list here. The primary topics of interest included the following:

- The need for regional and (or) local site understanding

- Mapping of the historic extent of grasslands and mapping as a tool for understanding and managing of species of concern

- The overall interest and appeal of native grasslands to the public, as well as access issues

- The importance of pollinators; pollinator networks, indices, and habitat; and the public appeal of pollinators

- The critical role of grassland remnants, as well as risks and unknowns associated with them: location, quality, management, conservation status, and future change 
What do you feel is most needed to increase public support for grassland conservation? (Select only one top issue.)

\section{9 responses}

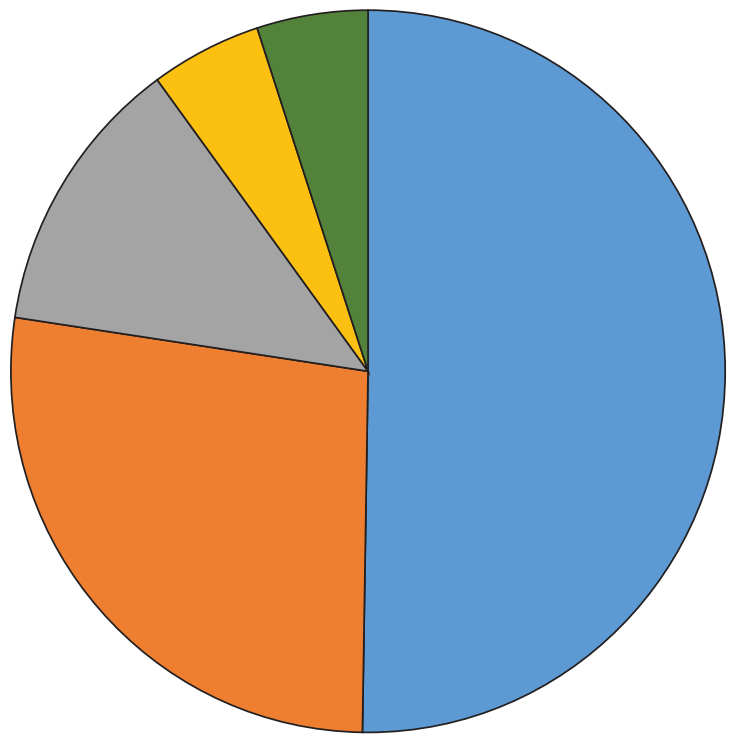

\section{EXPLANATION}

Increased awareness of the issue $(50 \%)$

An attitude that recognizes and supports grassland management and conservation $(27 \%)$

Increased knowledge and understanding of issues (13\%)

Funding (5\%)

Willingness to take action (volunteer, advocacy) (5\%)

Figure 2.3. Needs for increasing public support for grassland conservation identified by survey respondents.

\section{What do you feel is the biggest barrier to effective grassland management? (Select only one top issue.)}

\section{9 responses}

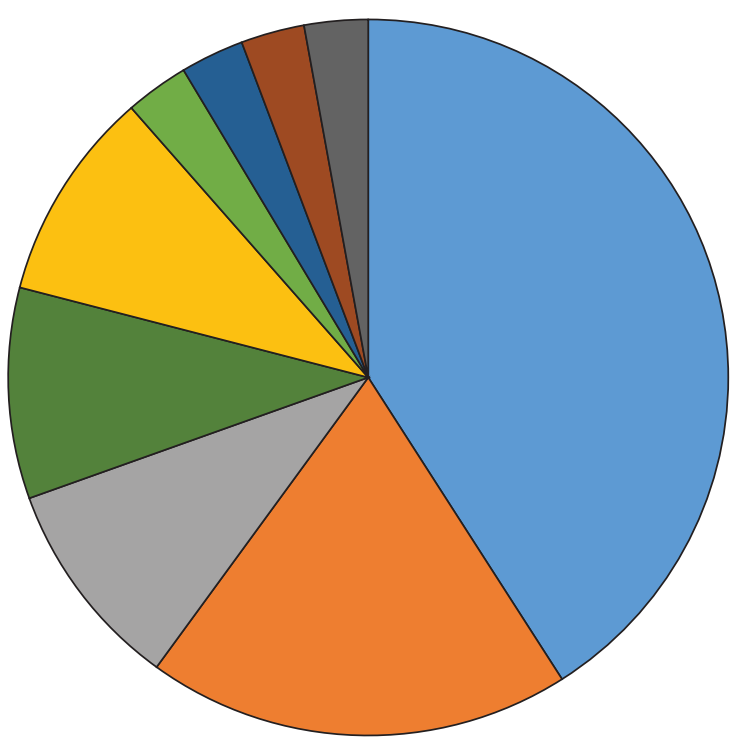

\section{EXPLANATION}

Limited funding (43\%)

Limited staff and personnel time $(20 \%)$

Limited or outdated scientific information $(10 \%)$

Lack of public awareness and support $(10 \%)$

Challenges translating science into management $(10 \%)$

Limited access to the existing scientific information $(3 \%)$

Institutional or administrative barriers (3\%)

Competition with traditional practices on private land $(3 \%)$

Institutional, administrative, and land-ownership barriers (3\%)

Figure 2.4. Perceived barriers to effective grassland management identified by survey respondents. 
What general categories of research are most needed to better support management of grassland species and habitats? (Select all that apply.)

39 responses

Grassland mapping and connectivity

The role of prescribed fire

Climate change including hydrology

Pollinator networks

Inventory of species of concern

Research on individual species of conservation concern

Land use change and urbanization Grassland resiliency including seedbanks

Basic research on grassland ecosystems Invasive species

Other (miscellaneous)

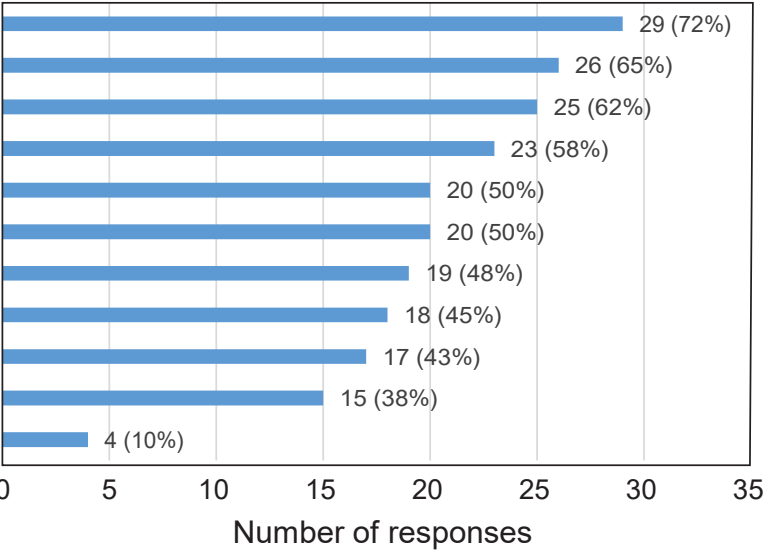

Figure 2.5. Research needs to support management of grassland species and habitats identified by survey respondents. 
For more information about this publication, contact

Director, USGS Lower Mississippi-Gulf Water Science Center 640 Grassmere Park Drive

Nashville, TN 37211

615-837-4799

For additional information, visit

https://www.usgs.gov/centers/lmg-water

Publishing support provided by the

Lafayette Publishing Service Center 


\section{$\frac{\mathbb{3}}{\mathbb{3}}$}

